\title{
THE
}

\section{AMERICAN HANDBOOK}

$$
\text { of }
$$

ORNAMENTAL TREES. 



\title{
THE
}

\section{AMERICAN HANDBOOK}

\author{
OF
}

\section{ORNAMENTAL TREES.}

BY

\section{THOMAS MEEHAN, \\ GARDENER.}

P H I A DEL P I A :

LIPPINCOTT, GRAMBO, AND CO. 1853. 
Entered according to the Act of Congress, in the year 1853, by LIPPINCOTT, GRAMBO, AND CO.,

in the Office of the Clerk of the District Court of the United States in and for the Eastern District of Pennsylvania. 
To

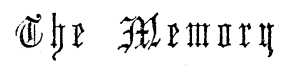

OF

JOHN BARTRAM,

THE

PATRIARCH

OF

AMERICAN ARBORICULTURE. 



\section{ADVERTISEMENT.}

A sMaLL work on the hardy ornamental trees in cultivation, has long been a desideratum.

The literature of other countries is well represented in this respect; the author offers the present volume as a small advance towards placing America in the same position.

His original design was to bring out a small volume for the numerous admirers of the indefatigable Botanist, BARTraM, describing the trees now growing in his far-famed old botanic garden. After the notes were prepared for this object, he was induced by the kind encouragement of his friends, and in the face of a great public want, to throw them into their present form. In order to make 
the work of standard accuracy, nothing has been admitted into the body of the work that has not been the result of the personal experience of the author. No tree is described as being in cultivation which the author has not himself seen ; and in most cases, the reader is referred to the tree, with its height and dimensions, from which the description is taken. The Appendix at the end of the work contains principally those trees which, though in cultivation, are too small to form a correct estimate of their value in ornamental gardening.

The work is offered solely as an aid in practical affairs, without any high pretension to its being a contribution to scientific literature. Hence the arrangement is alphabetical and the descriptions are brief. The botanical characters are for the most part compiled from various authors. In the Pinacece, Loudon has been principally consulted. The references to the natural orders are to those 
as developed by Lindley in the "Vegetable Kingdom," on the system of Endlicher, which is now generally followed by botanists. The rest of the work is entirely original. If any resemblance is observed between the author's remarks and the writings of others, it must be attributed to his earlier studies, which have become so blended with his observation and experience, as to make what perhaps properly belonged to others originally, now seem to him to be his own.

The nomenclature is not probably what a scientific writer would adopt, no particular author being exclusively followed. In a work intended for extensive popular use, it was thought better to adhere to popular names; and, as the names of the authors of both the generic and specific terms are given in full with each name, no confusion can arise on that score.

Having said thus much of his work, the author would gladly lay down his pen. But 
he cannot rule out the claims of the public to know something of the man who presumes to offer rules for its guidance. He would briefly state that, reared from infancy amongst extensive collections of trees, they became by circumstances as well as by taste the study and the hobby of his riper years. These advantages, together with a two years' study of trees in the celebrated gardens at Kew, with the subsequent practice of his knowledge in many superior establishments, amongst which he would here enumerate Rosedale, the nursery of Robert Buist; Bartram Botanic Gardens, now the property of A. M. Eastwick, Esq., and Springbrook, the country-seat of Caleb Cope, Esq., are, as he trusts, sufficient to induce him to appear without presumption before the public in an author's capacity.

He would here farther return his thanks to his numerous friends for their kind assistance. Particularly to Dr. William Darling- 
ton, of West Chester, at whose suggestion the work was originally begun. To A. M. Eastwick, Esq., to whom not only the author, but the public at large are indebted for the zealous care and watchful jealousy with which everything connected with the finest collection of full-grown trees in the country is preserved; to Caleb Cope, Esq., the ex-President of the Pennsylvania Horticultural Society, he is also indebted for much valuable information and suggestions, as well as to Thomas P. James, Esq., Secretary of the same institution, Messrs. R. Buist, of Rosedale, and John Evans, of Radnor.

Philadelphia, September 23, 1853. 



\section{INTRODUCTION.}

Trees are essential to an American home. The frame building, the first pointer to the young mechanic in his arduous path towards an honorable independence, is imperfect without the idea of shade trees surrounding it. And when, as he proceeds onwards, prosperity and plenty, smiling on his genius and on his talents, suggest the idea of a suburban residence, he dwells with pleasure on the vast variety of ornamental flowering trees, producing each month a succession of beautiful novelties, clothed with an endless variety of ever-changing foliage, administering equally shade and shelter for the body with food and enjoyment for the mind, which are pictured with it. Perhaps fortune has chosen him 
one of her special favorites. He becomes a man of wealth. Being a man of taste, endowed with an active sympathy for the charms of nature; alive to the keenest relish for landscape beauties; he has seen in his travels some of the fairest specimens of nature's handiwork in forest scenery, and resolved on forming a country-seat where he

"—_ with unsparing hand,

May cull the beauties of each land, And blend them in that favored spot,"

and aim at producing in one whole a pleasing picture of garden scenery, out of the materials nature has scattered so bountifully in various parts of the world.

To aid the mechanic in the choice of proper trees for his dwelling, and in their proper treatment; to assist the active business man in most effectually embellishing his residence, and combining the most beautiful with the most useful, and to point out to the 
retired citizen the principles by which the most pleasing effects from trees can be derived, as well as the most successful modes of rearing, planting, and cultivating them, are not among the least aims of the author; and are, as he believes, compatible with the original and main design, as already stated. 



\section{HANDB00K}

\section{OF \\ O R N A M E T A L TREES.}

I. OF PROPER SOIL.

1. EACH kind of tree has a soil peculiarly its own. In that soil it will do better than any other tree. The subject, then, is one of some moment.

2. Science may some day explain this with exactness; practice and experiment have taught us chiefly what we know so far. They have taught us that an oak, beautiful on our neighbor's clayey soil, would languish in our light sandy loam; and a pine on ours-"the envied of all beholders" would be as equally uneasy on his stiff ground. We have been enabled to learn what trees are well adapted to certain soilsin what soil any given tree will do well. 
3. This is of more importance to the man of small means, than to the man of fortune. The latter can have any tree he chooses, because he can make the soil to suit. The other cannot afford the expense-he must select the tree that suits his soil.

4. To illustrate the evil of inattention to soil, take the silver maples employed as shade trees in Philadelphia; where they are more generally used than any other tree. You may find it in every situation, till you believe that shade tree and silver maple are considered synonymous. For ground wet or dry, for soils light or heavy, it is all the same. Thus, it often finds itself in circum. stances every way unsuited to it. The leaves become small; the growth short and meagre; the trunk hide-bound, and the branches covered with mosses and lichens. They live and grow-perhaps for years-but never to satisfaction. Scores of such specimens may be seen at any time in our streets. The blame is too often thrown on the wrong source. The nurseryman is charged with selling bad trees, and the remedy sought for in trees purchased from 
another dealer, "which also, in their turn, must follow them."

5 . The number of species and varieties is now so great, that a fine collection of trees may be had in even a piece of ground with one uniform soil. Variety is generally pleasing; and the smallest lot might as well have its half-dozen trees of different kinds, as in one monotonous sameness. If one tree only be wanted, I prefer it to be different from one's neighbor's adjoining. In addition to the charm of variety, which is added to the pleasure of the shade, emulation has here an innocent outlet for its course, which will not fail to bring its gratifying reward.

6. One objection to variety, so far as shade trees are concerned, is its cost. A nurseryman can afford to sell a quantity of one thing for less, than for small lots of different ones. But, on reflection, few would be willing to forego the pleasure of that variety which is one of the charms of natural beauty-one of the means by which we contrast that which is superior with that which is beneath-and rest satisfied with the only change brought by the seasons, and the 
only pleasure that brought by its shade, when a trifling cost in the original outlay will "add all these things unto them." The saving of a dollar in a gratification which is expected to last for life, is a consideration which will have little weight when duly reflected on. A little extra expense in a selection of trees, a little extra thought on appropriating each to its most proper soil, and a little extra care bestowed on their removal and replanting, will be amply repaid in the future beauty, variety, health, and luxuriousness of shade trees.

II. ON THE CHOICE OF TREES.

7. For shade trees it is considered advantageous to possess the property of transplanting easily. This is a great reason why certain trees become so popular in some districts as to give them a character. But, in reality, there are no trees difficult to transplant. When the true principles of the operation are understood, a beech may be transplanted as easily as an ailanthus, or a sour- 
gum as a maple. This I hope to make plain to the reader as we proceed.

8. In choosing trees, prefer those raised in a nursery to those growing naturally in the woods. Most persons are aware of the difficulty of getting the latter to do well. A glance at the nature of roots will teach us the reason. There are two sets of roots to most trees, perhaps to all. One consists of fibres, the sole office of which is to draw matter from the soil for the use of the tree; the other of true roots, which extend and keep the tree in its position, affording at the same time channels for the conveyance of the matter absorbed by the fibres. This distinction must be well noted. Fibres, as I have repeatedly proved, are annual, dying out after a season's service. New fibres make their appearance as the extending roots grow; and are, consequently, farther away from the collar of the tree in proportion to its age.

9. The roots of trees have their peculiarities of divarication as well as the branches. Some trees grow erect, or horizontal, making few side shoots, and looking always sparse 
and thin; others branch and re-branch in every direction. So it is with their roots. The sour-gum throws out a few strong roots, scarcely making a single fork; while the linden throws out an abundance of rootlets in every direction. If we attempt to take up a specimen of the former by the common practice, that is, by opening a trench but a few feet from the trunk, we find that though we may have a great many roots, we have very few or no fibres. They are left with the roots in the ground, at their extremities. Such a tree is reduced to the condition of a mere cutting, and without the treatment proper for a cutting, cannot grow. Trees taken up by the same mode, that have an abundance of branching roots, are more likely to have fibres near the stem, and so succeed. This constitutes the chief difference between a tree that will "remove easily" and one which will not.

10. It should be an early inquiry whether a tree proposed to be transplanted have the above-mentioned conditions of success or not. A tree from a nursery has been transplanted when very young, perhaps several 
times. The repeated cuttings off of the young roots cause them to branch out numerously, attended, of course, by an abundance of fibres. That is exactly the tree for the planter. Trees from the woods will be in a worse case. Where they are particularly desired, there are two ways of procedure. We may dig out a space two feet deep, at from four to six feet from the trunk of the tree, according to its size, which will cut all the roots to that depth. Immediately replace the earth, into which they will fibre. The following year the tree may be removed with safety. In the other case, the roots should be followed to their extremities, the fibres gathered together carefully, and rolled up with the roots towards the trunk of the tree, where they can be protected from in. jury. The ball of earth on which so much care is given to cultivate trees, is of little importance in this case. There being but few fibres at the base, the ball can be of slight service, while it materially adds to the expense, and is actually a drawback by rendering the tree more unmanageable.

11. In these two modes of removal, suc- 
cess greatly depends upon the operator; a careful, persevering, determined hand, performs more, and with better results, than a hasty, undecided, and unpractical individual. The latter mode, in the right kind of hands, will give the most satisfaction in the end.

\section{ON RAISING TREES.}

12. For reasons already explained in the last section, trees are far better for the planter when raised artificially. Each tree's peculiar treatment will be noticed in another part; here we may note a few generalities.

13. Whenever it is convenient to raise trees from seeds, they will become most vigorous; though, under favorable circumstances, cutting layers or grafts, will sometimes equal or excel.

14. Many seeds lie two years in the ground before they grow. Anything that will assist the decomposition of their shells or outer cases, hastens their germination. Applications of oxalic acid, or boiling water, have been found useful, as well as allowing the seed to lie in a heap and ferment; or even 
by freezing them for a short time by packing them in ice. It is a fruitful field; but few discoveries have been made in it.

15. Trees of rapid growth should be transplanted at the end of the first season. In other cases, they may remain two years in the seed-bed.

IV. THE BEST SIZE FOR TRANSPLANTING.

16. This is a much disputed point. There are many good reasons for preferring large trees. The man who has become superior to the active duties of business, through a long course of years, and desires to pass the remainder of his days in the peaceful retirement of a country-seat, cannot afford to wait till young trees grow up with their grateful shade. He will prefer large trees. Taken up properly (see par. 10), and at a proper season (par. 21), they will succeed perfectly, and the immediate object be gained.

17. Such trees, however, never grow with much luxuriousness. Young thrifty trees, under favorable circumstances, equal them in a few years, and eventually go ahead. 
Besides, there is great pleasure to be derived from watching each year's luxuriant growth. The gratification which immediate shade is calculated to afford, is more than balanced by the pride we feel in pointing to a thriving tree which, but a few years ago, we could have put into our coat pocket.

18. Where trees have to be procured frorn a distance, or a nursery in general, young trees should always be preferred. The haste unavoidable in a nursery at the planting season, is unfavorable to great care in lifting them; while the readiness with which small trees can be taken up, and the facilities they. afford for careful packing, is a powerful argument in their favor.

\section{THE BEST SEASON TO PLANT.}

19. When the principles of successful planting are understood, trees can be removed at any time. A tree on being transplanted is, in some respects, in the condition of a cutting. Let us inquire, then, what are the principles of propagation?

20. Cuttings are taken generally from half 
ripened wood, are planted in light or sandy soil, and plunged in material a few degrees warmer than the atmosphere. Over the cuttings bell-glasses are placed. These are the main points-variations being made to suit peculiarities of each kind. Now for the principles. Half-ripened wood contains the "descending sap," out of which roots are formed. Cuttings are "too young" when the sap has not been elaborated; "too hard" when the descending current is feeble, or has ceased. The sandy soil admits air, which is essential to the formation of roots. Bottom heat excites the base of the cutting, encouraging it to form roots before the top starts into active life. Bell-glasses prevent evaporation from the leaves and stems, checking their demand for nutriment till the roots are formed to supply them. Let us carry this illustration to our subject.

21. In planting, the immediate object is to get a speedy formation of new roots or fibres. The best time to plant, then, will be when the earth is a few degrees warmer than the atmosphere, and when the elaborated sap is 
descending and active, and the tree itself least likely to suffer from excessive evaporation. That time is the autumn; at the fall of the leaf.

22. Autumn planting, however, has its disadvantages. The soil is generally very dry and unmanageable. The tree comes up with difficulty, and the new fibres dry up as fast as they push. Another disadvantage is, if we wait till the fall rains have deeply penetrated the soil, there is danger of having to leave the operation unfinished by frost. If the planting be not very extensive, it is much better for the tree to apply water when requisite, and have it done in the best time. The future health of the tree will repay the additional expense.

23. Spring planting is most usually followed. The ground is so pliable, it seems to save so much labor, and the work can go right ahead to completion. This is all that can be said in its favor.

24. Winter planting, or the "Frozen ball" system, is sometimes adopted. In the early part of the winter, a hole is prepared for the tree, and the tree itself prepared with "a 
ball" just ready for removal. When the ball is frozen through, it is taken off to the spot prepared for it, suffered to thaw, and then the hole filled up. I do not approve of this system, having seen it fail on a very extensive scale. The frost and atmosphere together, seem to act injuriously on the cut and exposed roots; besides, as I have already observed (par. 10), no amount of "ball" can compensate for a want of fibres.

25. Though I lay down the rule that autumn planting is preferable under most circumstances, it can be carried out in any season of the year. I have planted in every month for experiment sake. The worst period is just after the tree has burst forth its leaves in spring. Success is more probable every succeeding month till the fall, when the most favorable period for the process has arrived. There is a regular ebb and flow, like the tides and the seasons, in the rise and fall of the sap.

26. I will give one illustration to accompany the last paragraph. In one of my situations, a fine apricot-tree had to be transplanted or destroyed, in the month of June, 
to make way for some alterations in a carriage house. The fruit was at the time as large as pigeons' eggs. The young shoots were cut back, as far as they seemed "watery," to check evaporation. The roots were watered, and covered with damp mats as fast as they were exposed. It was taken out without the particle of a ball, planted at once, and finally well watered. Not a leaf withered. It was not watered again the whole season. The next spring it was a sheet of blossom, and had the curculio been well disposed, would have borne a splendid crop.

\section{PRUNING.}

27. Is it necessary to cut back the branches of a tree on transplanting? As much so as it may be necessary to cut off a man's limb to save his life. In either case, it is a necessity upon which the operator might well ponder, and hesitate to act.

28. If fall planting be adopted, the elaborated sap, eontained in every branch, will assist in the formation of roots. As there is 
little or no evaporation from the tree in the winter season, the branches can do no harm any way; and by the spring, the tree will have made roots to serve them.

29. In spring planting also, if the roots have an abundance of fibres, cut nothing away; they can support all. 'If otherwise, pruning must be resorted to, or the sap will be dried out of them before the tree can raise a necessary supply.

30 . The whole question is reduced to one of evaporation. If there be fibres enough to sustain great evaporation, the less cut the better.

VII. THE OPERATION OF TRANSPLANTING.

31. The common mode of planting is to dig out a hole, stick in a tree, and leave the rest to nature. This is not care enough. A tree will repay reasonable attention.

32. In preparing a piece of ground for planting, few operations are more beneficial than draining. Some trees, certainly, thrive in swamps; but these are little employed, 
and comprise but a small section of ornamental trees.

The majority thrive best in well-drained soil. I know of no soil, except those on sandy or gravelly substrata, not improved by draining.

It frequently renders a poor soil permanently fertile. By an underdrain a channel is opened beneath the surface, which draws down the rain, bringing with it the various gases mixed with it, as well as the many fertilizing ingredients always found at the surface, all of which would otherwise have been washed away to the nearest stream. A piece of ground well supplied with underdrains, from the great quantity of air-spaces the draught of water through it occasions, is always moist without the possibility of becoming soured by saturation. So much do I value draining as a means of highly and permanently improving land for trees, that were I offered a thousand dollars for manure, or five hundred to be expended in draining, previously to planting a piece of ground, I would unhesitatingly choose the latter. If 
well executed, the most substantial and lasting benefit would ensue.

33. In some cases, natural causes prevent draining, or the piece of ground would not warrant the outlay; the expense being greater than the corresponding advantages. In such cases, if the ground be very wet, I would plant on the surface instead of below it. I have described my practice in this respect in the Horticulturist, for 1849. The ground is first trenched, or dug deep, the tree placed on the desired spot, and the earth spread over the roots; the whole, when finished, mound-like. The appearance of trees thus planted is objectionable. The ground appears to an observer to have been lowered, the trees indicating the original height. Such appearances detract from that natural looking beauty a garden ought to exhibit. The mode can only be tolerated where the ground cannot be drained.

Bad as its appearance is, it is preferable to seeing trees planted in holes which, in reality, become wells of stagnant water, with their tenants rotten at the roots, their trunk the sport of every passing breeze. 
34. One of the commonest errors is deep planting. The fibres or feeding roots of a tree, cannot exist long far beneath the sur. face. Abstracting a portion of their supplies from the atmosphere, they must be contigu. ous to it. I have seen peaches, maples, and elms, killed in six months by having the soil about them raised fifteen inches. Those who delight in seeing how nature works, may look at any old forest, where the fibrebearing roots cover the surface like railroads on a modern map. The tap roots only, bearing no fibres, and evidently acting solely as supports to the tree, penetrate far into the soil.

35. A fear of the tree blowing over, or becoming parched in summer, is a common motive for deep planting. A tree planted with long roots (par. 10) will never blow over; the weight of soil on the roots keep. ing them in their position.

When otherwise planted, they should be securely staked; and if liable to parch, the soil ought to be covered with short grass or other substance, as a mulching. If, however, the principles of planting, as I have explained 
them, are understood and attended to, there will seldom be occasion for one or the other.

VIII. ON THE SELECTION OF KINDS OF TREES.

36. Firstly, we have to consider what the tree is wanted for; whether for shade, for ornament, or both combined; for utility or beauty; whether a rapid growth be desired, or the highest effects of the art without reference to time; whether they are to be planted singly, or together in masses?

37. A shade tree should have a widely spreading head, abundant leaves, or dense foliage. It should bud forth early in spring, and retain its leaves late in autumn. It should also be free from unpleasant odors, and liability to attacks of disease or insects. All fruit-trees are objectionable. Who would choose a Lombardy poplar for a shade tree? The honey-locust has too fine a foliage. The odor of the ailanthus is unpleasant. The Kentucky coffee buds late, and the American buttonwood is too unhealthy. Still, there is great scope for variety. Fine selections can be made from amongst the horse-chestnuts 
and buckeyes, maples, some birches, ashes, tulip-tree, magnolias, hop horn-béan, English buttonwood, the oaks, sweet-chestnut, sophora, and in some parts or situations, lindens and willows.

38. But it is by no means in the majority of cases that trees are planted for the mere luxury of the shade they afford, or their utility in screening disagreeable objects. They are valued for the effect they have on the landscape; the beauty they exhibit in their forms; the cheerfulness that dwells in their foliage; the gayety that bursts from their opening blossoms, charms; and the contrasts they make with each other, please. To these, if they combine harmony with surrounding objects, expression of the artist's ideas, or association with classic history, or remarkable occurrences, they afford additional interest. These are points which few can master thoroughly, without long and careful study. Yet, on the perfection of this knowledge, depends the production of the most pleasing effects from ornamental arbori: culture.

39. The effect to be produced by trees, 
should be particularly well studied. The object must never be lost sight of. Pleasure, in its broadest sense, is generally a main object; this is always to be derived from a perception of the beautiful. Unity, harmony, and appropriate fitness, are the essential elements of beauty; to these, then, must the planter's efforts turn.

40. The relation or fitness of a tree to the subject in connection with it, will be one of first importance in the study of effect. A tree, beautiful in some situations, and in connection with some objects, will fail to please under other circumstances. A tree out of character is as offensive to the cultivated mind as would be a dress of the finest satin on the back of a beggar. So, an idea attached to a tree by association, gives it a character which cannot be removed from it without violence. A traveller, accustomed to associate the cypress or yew-tree with churchyards or monuments, would be painfully struck on meeting an avenue of them leading to a mansion. The same ideas hold good in the peculiar character of trees, as well as in their associations. A magnificent 
deodar, or even a Norway spruce, solitary and alone, would look as ridiculous by the side of one of our western log-houses, as a noble, weather-beaten, rustic-looking oak would alongside a magnificent modern specimen of city architecture.

41. We often hear the remark that evergreens around a mansion look so beautiful. Others again give a decided preference to deciduous trees. This difference of opinion can be accounted for on philesophical prineiples, and does not originate from any variation in the principles of beauty. Evergreens are the accompaniments of the thoughtful and the reflective. As we advance in age, the fondness for them grows more devoted. Their unchanging character suits the reflective steadiness that characterizes old age, and which draws our affection towards them as to bosom friends. Deciduous trees are emblematic of lightness and gayety; the young and untutored will always prefer them. Our happiest remembrances cling around the old oak of our childhood's home, without a thought or a care for the holly or the pine. 
42. For these reasons evergreens should never preponderate around places, or in situations devoted to amusement or recreation. By schools, or places devoted to the young, they are objectionable in great numbers. Unsuggestive of lightness and gayety, they are opposed to the thoughtless, yet happy innocence of childhood. Wherever the aged love to resort, whatever is to have an air of solitude or peace, there is the spot which evergreens will adorn; here is the point from which they will really seem beautiful.

43. The selection of trees for effect can then depend upon no particular rule, fitness or appropriateness depending upon each circumstance; but unity and harmony are more general in their application.

44. Unity of design must not degenerate into formality; nor harmony into monotony. It is the frequency of this degeneracy that produces the opposite errors of irregularity and discord. One, in a mistaken view of unity, will divide his grounds into two equal parts, and an oak or an elm on one side must have precisely the same on the other, 
as if to balance the whole. Another, disgusted with such abortions of taste, plunges into the opposite error. His place has the appearance of having fallen into the hands of men of all principles, ages, and nations, each one of whom had successively stuck on a patch, till, between the daubs of so many brushes on their objectionable part of the picture, little of the original design is left.

45. Variety is not opposed to unity. The oneness should be in the outline; the more varied, then, the filling up, the better. The carriage entrance to an old mansion is often improved by a row of trees on each side. Each set of two placed opposite to one another, should of course correspond. One would as soon see beauty in one gate-post, or one eye being larger than the other, as to see anything different in this respect. Yet there could be no objection to the successive sets of trees varying in species or varieties, so long as no rule of harmony was broken thereby. A light, airy-looking tree, like the hemlock-spruce, should not be placed immediately after a rugged, artificial-looking Norway. Its gracefulness would be in part 
absorbed by the rusticity of the latter, and both lose by comparison.

46. This harmony of color, shade, and contrast, is of more importance in the general arrangement of trees in a garden, than in such an avenue as I have described. They are to be looked at in greater masses, seen from more distant points of view, or from more varied positions.

47. The colors, tints, and hues of the foliage at different seasons of the year, will then have to be more particularly studied. Much may be lost or gained in the effect of a single tree. The golden hue of a sugar maple in the fall, appears to great advantage followed by a sassafras with its rosy yellow tints; and this, again, followed by a red or swamp maple or tupelo, forms a beautiful combination. If we were to take away the sassafras and replace it with a British oak, the effect would be anything but pleasing.

48. Not only in color should there be harmony, but also in height, habit, and appearance. All violent contrasts are opposed to natural beauty. In the oft-quoted language of Ray, " nature never takes leaps," but pro- 
ceeds gradually step by step. Differing in variety, yet united in general principles, each clump or section of trees in a landscape will possess characters exclusively its own. Few mistakes can arise from planting trees simply; harmony and association with the objects alone being called for.

49. In planting for a wood or grove, it is frequently the desire to make a small place look larger. Every bend should possess some new or striking feature. A long walk around a wood will not please without an object. A visitor may be surprised at the extent, but to the proprietor it is wearisome. His pleasure can only be secured by a succession of ever present, yet ever changing objects of beauty along the course.

50. Thus the planter should be imbued with the principles of beauty. Without them his labors may excite only wonder at their extent, or surprise at their variety; with them, he combines lasting beauty-a source of unvarying pleasure and delight. 
IX. OF TREES INDIVIDUALLY.

AbIEs, Tournefort.-Nat. Ord.Pinaceæ. Monœcia, Monadelphia, Linn. Cones mostly pendant, seldom clustering, cylindrically conical; scales not thickened at the top. Leaves solitary, somewhat scattered, and arranged more or less in two rows.

1. A. Canadensis, Michaux. Leaves solitary, flat, toothed near the point, disposed irregularly in two ranks, each about half an inch long. Cones oval, terminal, scarcely longer than the leaves.-Hemlock spruce. Native of the Northern States.

It would not be exaggeration to pronounce this the most beautiful evergreen in cultivation. Beautiful as many of the new pines are, few approach this. It has regularity without formality; and, in any point of view, elegance and gracefulness. Its habit is frequently so erect as to approach the fastigiate; yet the ends of its branches are as pendulous as a Babylonian willow. Its color is not of that mournful cast so common to other Pinaceæ; nor of that consumptive- 
looking hue so connected with sickliness. Stepping between these it is suggestive of innocence and lightness, which cannot fail to attract admirers for it, in whatever situation placed. It will make the prettiest object when grown by itself; but it is a tree that has no aversion to company. The largest specimen at Bartram is ninety-four feet high, and eight feet four inches in circumference.

It thrives best in a light alluvial loam, contiguous to moisture; but is soon injured in wet situations. It will grow in the driest soils; but, unless the atmosphere is very humid, to little advantage. It is propagated by seeds sown early in the spring in boxes or beds of well-drained sandy loam, but slightly covered with soil, and kept moderately moist and shaded. When two years old they may be removed to nursery rows one foot apart in the row. When they have been thus raised, and once afterwards transplanted, they can be transplanted easily at any future time. They seldom do well removed from the woods.

2. A. Douglassir, Lindley. Leaves flat, comb-like in their arrangement, silvery be- 
neath; about one inch long. Cones about four inches long, and two broad, borne on the ends of the branches, with many sharp, linear bracteas at the base; ovate oblong.Douglass's spruce. Native of the states on the Pacific. Grows to one hundred and fifty feet high, and is represented to be one of the most beautiful of the tribe. The finest specimen I have seen in the neighborhood of Philadelphia is about five feet high, very vigorous and hardy. This is on a sandy, yet moist hill, with a south aspect. On a cold aspect, in a stiff loam, they do not succeed well. Most of the plants in the nurseries are raised from cuttings, which make fine plants; but many are now raised from seed obtained from their native places of growth. These should be sown as soon as received in pans of sandy loam, the seeds very little covered; and if they can be placed in the soil separately, with their sharpest ends downwards, it would be to their advantage. Sometimes the seeds will remain a year in the soil before germinating.

3. A. EXCELSA, De Candolle. Leaves scattered, quadrangular, curved, and sharp-point$5 \%$ 
ed. Cones cylindrical, terminal; of a rich reddish brown when ripe; five to seven inches long, one and a half to two inches broad.-Norway spruce.

There is a great diversity of opinion respecting the merits of this tree in a landscape. The objection is chiefly to the monotonous formality of its appearance; yet, when it is in a situation highly artificial or extra-natural-as near ornamental buildings, on rugged, rocky places, or on the tops of informal hills-there is probably nothing mcre beautiful. The finest specimen at Bartram is one hundred and twenty feet high, and seven feet two inches in circumference; beautifully clothed with branches to near the ground. It is growing on a light gravelly loam, on a substratum of gravel. It generally thrives best in a cool sandy loam, where the soil is always moist, but not wet.

Propagation, \&c., see No. 1.

4. A. NIGRA, Aiton. Leaves solitary, regularly disposed all round the branches, erect, very short, somewhat quadrangular. Cones ovate, about one and a half inch long, and three-quarters of an inch wide in the middle; 
the scales blunt, roundish, very thin, and when ripe, ragged and torn at the margin.Black spruce. Native of the Northern and Middle States.

In its native localities this tree often attains seventy feet in height, though its diameter is never great. It much resembles the Norway, but is not pendulous. It spreads horizontally like that species, but has a darker hue. It will grow alike in the lowest or the most elevated situations; on the rocky hill-side, or in a spot nearly swampy. It seems to thrive best in a cool, light loam. There are no very fine specimens now at Bartram, the largest is thirtyfour feet high by twenty-four inches in circumference.

For propagation, \&c., see No. 1.

5. A. Smithiana, Wallich. Leaves compressed, tetragonal, straight, somewhat awlshaped, sharp-pointed, one to one and a half inch long, pale green, and somewhat glaucous. Cones ovate oblong, solitary, four to seven inches long. - Smith's Himalayan spruce. Morinda. Himalayas.

This is said to grow about fifty feet high 
in its native country, and to surpass the Norway in beauty; its habit is not quite so pendulous; the leaves are longer, and of a lighter hue, and the whole habit seems grosser and more luxuriant. It seems to thrive best in a deep, strong loam, in an elevated situation, but not too much exposed to the sun.

Acacia, Willdenow.-Nat. Ord. Fabaceæ. Polygamia, Monœcia, Linn. Calyx 4 or 5 toothed. Legume dry, 2-valved.

A. JULIBRIssin, Willdenow. Without spines. Leaves with eight or ten pairs of pinnæ, and a small gland at the base of each petiole. Heads of flowers pedunculate, forming nearly a panicle. Native of the Levant; flowers in July. The julibrissin is a highly ornamental tree, resembling, but far excelling, in habit and appearance, the honeylocust. When it is old, it has a roundheaded character; its branches spreading very wide. Its foliage always gives it a graceful appearance; but when in flower, it is surpassed in beauty by few. It is perfectly hardy in Philadelphia, though liable 
to lose the tops of the young wood in severe winters. There are several fine specimens in the vicinity, some fifty feet high; the largest Bartram specimen is about thirty-five feet high by twenty-seven inches in circurnference.

It delights in a dry, rich loam, and a warm, open situation. It is cultivated from seeds, sown in a somewhat rich loam early in the spring. In the fall they are taken up, tied in bundles, and kept through the winter in a cool, not damp cellar, packed in dryish loam. In the spring, they are planted out in nursery rows, eighteen inches apart, and generally remain out the winter following.

Acer, Linnous. - Nat. Ord. Aceraceæ. Polygamia, Monœcia, or Diœcia, Linn. Calyx 5-lobed, sometimes 5-petalled. Capsules two, each terminated by a wing.

1. A. campestre, Linnceus. Leaves cordate, small, with lobes. Wings of the fruit spreading right out. Bark often corky.English maple. Native of Britain.

This seldom reaches thirty feet high in its native country. Its leaves resemble those 
of the gooseberry. It is valuable in American gardening, from the late period of the season to which it retains its foliage. It takes a sharp frost to destroy its verdure. It has a very stiff and formal habit of growth, yet one that renders it very appropriate for planting at a corner, to make a reason appear for a bend in a walk, or to accompany any formal piece of work. There is a fine specimen on the grounds of Caleb Cope, Esq., and several in other places near Philadelphia.

It is readily propagated from seeds sown in the fall as they ripen, in a bed of sandy loam. If kept till the spring, they seldom come up till the next season. When a year old, they may be planted out in nursery rows one foot apart. In two years afterwards, they may be taken up and planted where. they are to remain, or in rows two feet apart till wanted. It is often propagated from layers. A plant is cut down to within a few inches of the ground. The numerous shoots that spring up may be gently twisted any time after the fall of the leaf till the bursting of the bud, and a little soil thrown in amongst 
the shoots till the twisted parts are covered; or the shoots may be bent down to the ground, notched and slit as in the usual mode of layering, and sunk a few inches in the ground. The first mode saves labor; the last, after waterings.

2. A. DASYCARPUM, Ehrhart. Leaves palmately 5-lobed, deeply sinuated with the sinui acute. Flowers in clusters, before the leaves. Ovaries downy. Seeds with large wings.-Silver maple. Native of the Northern and Middle States.

One of the finest of our native trees. It is so often seen in a half-starved, stunted state, as a street tree, that one might be incredulous of its beauty when under proper circumstances, from a mere description. Unless in favorable soil, it does not make a deep shade-but in that case few can excel it, and its shade is so mellowed by the silvery under surface of the leaves, as to make quite a pleasing effect. It branches out pretty near the base, and spreads to a great extent without much ramification, which renders it liable to be broken at times by heavy winds. The finest specimen at Bartram is seventy. 
seven feet high, by six feet eight inches in circumference.

It thrives best in a deep rich loam, or in a gravelly loam contiguous to moisture, as on a declivity by the side of a stream. It is propagated by seeds, as described in No. 1 .

3. A. montanum, Aiton. Leaves cordate, 3-5-lobed. Lobes acuminate, coarsely serrate. Racemes simple, pendulous, sometimes nearly erect. Petals linear.-Mountain maple. Native principally of Canada and the Alleghanies.

This tree is scarce in our nurseries. It is valuable to the landscape gardener for the variety of its red colors in the fall, and deserves more extensive culture. It does not grow large when on its own roots; but budded on the strong-growing species, makes a fine tree.

4. A. Nigrum, Michaux. Leaves 3-5-lobed. Broader, and less bayed and cut than $A$. Sacharinum, slightly downy beneath. Leafstalks shorter and stouter.-Black sugar maple. Native of the Middle and Southern States.

This tree, in cultivation, so much resem- 
bles the true sugar-maple, that few can distinguish them. When in a wild state, it is generally thought to present a very distinct and peculiar appearance.

In cultivation it has a darker hue than the other kind, and may be readily distinguished in the spring by its coming into leaf a week or ten days earlier. The finest specimen I have seen is at Bartram. Though it is quite young, it measures fifty feet high and thirty inches in circumference. It is propagated by seeds, as No. 1.

5. A. PLATANoIDEs, Linnous. Leaves milky, broadly cordate, 5-lobed, coarsely toothed. Fruit divaricate. Flowers pendulous.-Norway maple. Native of the Northern parts of Europe.

A very ornamental tree in any situation. It does not incline to branch out so low down as some of the maples, while it has a more rugged and branching habit of growth. Its ample broad leaves give a fine shade, which is heightened by their dark green color. It is quite a peculiar tree, combining the artistic appearance of some trees with the rusticity of others. There are many situations in a 
landscape where it would be singularly effective. It is very hardy, and will thrive in any soil or situation. The finest specimen at Bartram is growing on an elevated situation, in a gravelly soil on a rocky substratum, and is sixty feet in height, and three feet two inches in circumference. In the fine arboretum of Mr. G. W. Pierce, near West Chester, there is a fine specimen near eight feet in circumference. There are also some fine specimens on the grounds of the Society of Friends, on Mulberry between Third and Fourth streets, Philadelphia.

For propagation from seed, see No. 1.

6. A. PSEUdo-Platanus, Linnoeus. Leaves eordate at the base, 5-lobed, unequally dentate. Fruit with long, large wings.-Sycamore.

This has a more formal appearance than the last, being more regularly round-headed. It is readily distinguished by its habit, which is stiff and little inclined to branch. The lobes of the leaves are more pointed, and there is a wide difference in the fruit. It is a fine object grown as a single specimen, attaining sixty or seventy feet high. It is a 
rapid grower, thriving in a deep rich loam; but growing pretty well in any situation, or under any circumstances. The young specimen at Bartram is about twenty-five feet high and forty inches in circumference.

It may be propagated like No. 1 .

7. A. RUBRum, Linnoeus. Leaves 3, nearly 5 -lobed, slightly cordate at the base. Ovaries smooth. Seed-vessels and stalks red or brown.-Red maple.-Swamp maple. Native of most of the States and Canada.

This tree, though it is naturally found in swamps and morasses, will thrive in any soil or situation. It is fortunate that it does so, as it is indispensable to the landscape gardener. Its bright scarlet fruit and flowers are amongst the earliest harbingers of spring; while its leaves, of every shade of red in the fall, add materially to the interest of the landscape. It has a very formal, regular head, though sometimes a specimen may be found with a somewhat rugged appearance. It varies very much from seed.

In a curved avenue on the grounds at Springbrook, in which there are many of them, there are almost as many forms either 
in habit, hue, foliage, or fruit, as specimens. One may prove a valuable variety. The fruit is almost green, and comparatively insignificant; while the foliage appears a week earlier than any of the others. The best Bartram specimen is forty-seven feet high and four feet in circumference. In favorable situations it doubles this.

It is propagated from seed, like No. 1.

8. A. SACCharinum, Linnceus. Leaves palmate, 3, 5-parted, smooth; lobes sharp, with coarse teeth. Flowers in drooping corymbs, on hairy or downy stalks.-Sugarmaple. Canada to Pennsylvania.

This tree has none of the graceful airiness of the silver-maple, or the rusticity of branches as the Norway; but excels them both in nobility of appearance. It has a stiff, regularly round head, generally in over proportion to the size of its trunk. It is much admired on account of the rich golden-yellow hue, often tinged with red, with which it is clothed in the fall. The finest specimen at Bartram is eighty-two feet high and five feet five inches in circumference.

Like most of the maples it is of easy culti- 
vation, doing well in any situation, except in the dry and confined atmosphere of a densely built city; and in most soils; but preferring a loose loam or one on a substratum of clay.

It is propagated as No. 1.

9. A. Striatum, Lambert. Leaves 3-lobed, rough, slightly cordate at the base, sharply and finely serrate; lobes acute.-Striped barked maple.-Moosewood. From Canada to Carolina.

Few trees show so much the effect of different circumstances as this. In England, when grafted on the Sycamore, it makes a tree three or four times larger than when in its native places of growth. At Bartram there is a young specimen on its own roots, growing, in a moist shady situation upon a substratum of mica which is about thirty feet high and sixteen inches in circumference; while in another part of the grounds there is another specimen growing in dry gravel; under the shade of a Norway spruce, which, though planted many years, has never arisen above the character of a shrub, perfecting its seeds every year. In the latter state, I pre6* 
sume it is the $A$. Pennsylvanicum, the moosewood of Linnæus.

It may be raised from seeds, cuttings, or grafts.

Assculus, Linnaeus.-Nat. Ord. Sapindacæ. Heptandria, Monogynia, Linn. Calyx campanulate, 5-lobed. Petals unequal. Stamens usually curved inwardly. Fruit bristly and muricated.

1. A. hippocastanum, Linnoeus. Leaflets 7 , obovately wedge-shaped, toothed.-British horsechestnut.

This tree, originally confined to Northern Asia (its native country), is now cultivated all over the civilized globe. It is one of the finest shade trees, and possesses in its handsome flowers appearing in May, a recommendation many others do not. It does not grow very lofty, being more inclined to spread and become round-headed, and on that account is one of the very best to stand out by itself as a specimen tree on a lawn or in a park. In deep rich loam it does well, attaining a great bulk in a short time, but in a dry or gravelly one, though it will grow 
pretty well, it is short lived, and seldom healthy. The old specimens planted by John Bartram, not being on congenial soil, are not remarkable; the largest being but fifty feet high and seven feet five inches in circumference.

They are readily reproduced from seed. When collected, lay them out of doors on the ground in a shady place, and slightly cover them with leaves. Guard them from vermin. Early in spring select a rich loamy spot, in which draw drills, and sow the nuts four inches apart, but just covering them with the soil. They will soon appear. In the fall following, transplant, to eighteen inches or two feet apart, to where they can remain till wanted. They also succeed well budded in July on the buckeye.

2. Æ. Ohinessis, Michaux. Leaves quinate, unequally toothed; leaflets nearly sessile. Flowers nearly yellow. - American horsechestnut, sometimes Ohio buckeye.

This species half unites the buckeye with the true horsechestnut, having the habits and appearance of the one, with the prickly fruit, the chief characteristics of the other. 
It is a small tree, attaining about forty feet, and thrives in a similar soil, and is propagated in the same manner as No. 1. The Bartram specimen is young, about thirty feet high, and two feet in circumference. A specimen in the arboretum of G. W. Pierce appears to be about fifty feet high, and is two feet four inches in circumference.

3. E. RUBICUNDA, De Candolle. Leaflets 5-7, unequally serrate. Petals 4 , with the claws of the petals shorter than the calyx. Stamens, eight.-Red horsechestnut.

Though a native species, it has not been long in cultivation. It is undoubtedly the handsomest. The flower-spikes are very large, of a deep brick red, and do not appear till June. It has a vigorous habit when grafted on the yellow buckeye, which is its best stock. The Bartram specimen-I believe the finest in the country-is thirty feet high, and twenty-four inches in circumference, grafted on the British species.

The same treatment as Nos. 1 and 2 suits it. The seedlings occasionally produce car. nate-colored flowers. 
Allantus, Desfontaines.-Nat. Ord. Xanthoxylaceæ. Polygamia, Monœcia, Linn. Calyx 5-cleft. Petals five. Stamens ten, unequal. Ovary mostly of five carpels, membranous, 1-celled, 1-seeded.

A. Glandulosa, Desfontaines. Leaves pinnate; leaflets toothed at the base, with a gland at the base of each tooth.-Ailanthus: Tree of heaven. Native of China. Flowers in June or July.

Few trees have met with such a sad reverse of fortune as this. Its growth is very rapid, and as rapidly it grew in popular estimation on its first introduction. Latterly, the tide has set against it, and caused many to be torn up by the roots, and cast away. The late Mr. Downing's last and best essay was directed against it, and it will probably never recover from that stroke of his powerfully-directed pen. There are many who will agree with his pleasing arguments, and discard it on account of its bad propensity to throw up suckers, an argument that can be used against many other of our finest trees; and for its abominable stench for the week that it is in flower. These are its disadvan. 
tages. On the other hand, it is of very rapid growth, and, in appearance, often rivals the beauty of our own black walnut. In some situations, it does not sucker so freely as in others, and occasionally not at all. Severe pruning, or any external injury either to the roots or branches, seems to have considerable influence in the production of suckers. Having thus given both its merits and demerits, I leave it to its fate. Though I cannot recommend it as a lawn tree, yet in cities, where it is so difficult to keep trees healthy, its suckering propensities cannot injure anything in the street, and there its value, by its freedom from insects, may atone for its stench while in flower. The Bartram specimen is sixty feet high and seven feet in circumference.

Amelanchier, Medikus. Nat. Ord: Pomaceæ. Icosandria, Pentagynia, Linn. Calyx 5-cleft. Petals 5, oblong lanceolate. Styles more or less united. Fruit, a small apple, with 3-5 gristly cells.

A. Botryapium, De Candolle. Leaves ovate oblong, slightly cordate at the base, acumi- 
nate. Flowers in loose racemes; petals linear lanceolate.-June berry, shad-flower. Flowers in April. Native of most parts of the United States.

A pretty tree, fifteen to twenty feet high. It grows very slenderly, and with few shoots, unless in a very rich loam. The leaves have mostly a white silky appearance, and the flowers and succeeding berries are very ornamental. I have seen a specimen thirty feet high, and three feet in circumference, but it is probably turned into "post and rails" by this time.

They may be propagated by seeds, but in English nurseries are generally grafted on the hawthorn, and sometimes on the pear and quince. Seeds produce the finest trees. The latter modes produce plants quickest.

Amygdalus, Linnoeus.-Nat. Ord. Drupaceæ. Icosandria, Monogynia, Linn. Calyx 5-cleft, petals 5. Fruit a drupe. Seed an ovate nut with reticulate furrows.

A. PERsicA, Linnoeus. Variety pendula, with the branches drooping, is a very pretty ornamental peach, when budded as tall as it 
can be got, on a tree of the common kind, suffered to grow up six or eight feet for the purpose.

Andromeda, Linnceus.-Nat. Ord. Ericaceæ. Decandria, Monogynia, Linn. Calyx 5-parted. Corolla monopetalous, globose, with a contracted 5-parted mouth. The segments reflexed.

A. ARBOREA, Linnoeus. Leaves oblong oval, tapering to a point, thickly toothed. Flowers in terminal panicles. Corolla slightly downy.-Sorrel-tree. Native of the Southern States. Flowers in August.

A very handsome tree in favorable localities; in others it dwindles down to a mere shrub. It is fond of a gravelly, light loam, where the roots can be in proximity to a spring. Covered with its white blossoms it is very pretty, and adds to the gracefulness its light twiggy habit always presents. The prettiest specimen at Bartram is sixty feet high, and four feet in circumference.

It is raised from seed obtained from their native places of growth. These must be sown in fine sandy peat, sheltered from heavy 
rains, yet kept regularly moist. When they are about a foot high, plant one foot apart in rows, in sandy loam, where they may remain till wanted.

Anona, Linnous.-Nat. Ord. Anonaceæ. Polyandria, Polygynia, Linn. Calyx composed of three sepals connected at the base. Petals 6, innermost smallest. Fruit, manyseeded, pulpy.

A. GLABRA, Linnceus. Leaves ovate elliptic, wedge-shaped, smooth. The three outer petals nearly round. Fruit large, thick, and fleshy.-Papaw. Native of the Middle and Western States. Flowers in July.

The stem is very straight, of a peculiar gray color ; and the leaves have a very dark and glossy-green appearapce. To be grown to perfection, it should be treated as a single specimen, in rich soil, in an open situation. Then the tree has a very pretty conical appearance. In stony soil it is liable to throw up suckers; but these are easily kept down. In Philadelphia, it bears fruit freely in the autumn. The largest specimen at Bartram is thirty feet high and two feet eight inches 
in circumference. There are some very healthy luxurious specimens in Marshall's Garden, in Chester County, Pa.

I have been unable to determine whether the A. triloba, Michaux, is distinct. My friend, Col. Carr, late proprietor of the Bartram Botanic Garden, considers them so. I am inclined to think them identical from the descriptions, and have adopted the original name, as the plant I describe is so known in the nurseries.

It is readily propagated from suckers or seeds.

Aralia, Linnoeus.-Nat. Ord. Araliaceæ. Pentandria, Pentagynia, Linn. Calyx very small, mostly 5-toothed. Petals 5, expanded or reflexed at the apex. Styles very short, permanent, spreading. Fruit, a berry; usually 5-celled, and striated.

A. spinosa, Linnoeus. Stem and leaves prickly. Panicles much branched.-Angelica tree. Club of Hercules.

Thinly scattered through the Middle, Southern, and Western States. When full grown, and covered in the fall and winter 
with its purple berries, it is a pretty, though small tree. The coarse, spiny branches also give it a picturesque appearance.

It has the advantage of thriving in dry, barren, stony places, where few other things will grow. When once established, it must always remain; every attempt to destroy it by digging it up, is retaliated by a regiment of suckers. Let it alone, and it is not so troublesome. The finest Bartram specimen is fifteen feet high, and twelve inches in circumference.

It is easily propagated from cuttings of the roots, or by seeds.

Araucaria, Ruiz and Pavon.-Nat. Ord. Pinaceæ. Diœcia, Monadelphia, Linn. Male flower. Pollen contained in ten to twenty cases, pendant from the apex of the scale. Female. Ovule solitary, joined to the carpel or scale. Leaves imbricate.

A. Imbricata, Ruiz and Pavon. Leaves in eights, ovate lanceolate, with small permanent spiny points, stiff, and attached to the tree for several years. Cones roundish ovate, about eight inches long, and seven broad. 
Seed about two and one-fourth inches long, and one broad.-Chili pine.

This picturesque evergreen is perfectly hardy when grown in a light loam, and protected from sun in the winter season. "It sometimes loses its side branches when young, in severe winters. In cold stiff soil, especially if exposed to the sun in winter, it generally fails.

It is propagated from seeds obtained from its native country. These should be sown in pans or boxes of light loamy soil, with the narrow ends of the seeds downwards, as soon as received. Put them in a frame where they can be kept evenly moist, without liability to saturation from rain. An abundance of air is essential. Avoid much heat, or an abundance of vegetable matter in the soil. When they are a few inches high, pot singly into four-inch pots; or, if they can be protected, plant out in a bed four or six inches apart.

Betula, Linnceus.-Nat. Ord. Betulaceæ. Monocia, Tetrandria, Linn. Aments of the sterile flowers long and cylindrical; scales 
ternate, the middle ones bearing the stamens. Pistillate aments ovate oblong; scales trifid, 3-flowered. Seeds (or fruit) with a membranous edge.

1. Betula alba, Linnous. Leaves ovate, acuminate, serrate. Stem covered with white bark.-White birch. Native of the North of Europe.

The bark gives this a peculiar character; and the slender drooping branchlets, and elegant shining green foliage, combine to render it one of the handsomest of trees.

There is but one specimen referred to this species at Bartram, but it so closely resembles $B$. populifolia as to require a nice examination to determine it.*

It will thrive in the most barren soils where little else will grow, the roots extending just beneath the surface, and probably drawing much of their sustenance from the atmosphere. This circumstance renders them very easy to transplant, and where any kind

* The nomenclature of the Birches is in great confusion among practical men. They are worth a closer study. 
can be got from the woods while young, it is preferable to raising them from seeds. They may be raised from seeds sown either in fall or spring, on a bed of light sandy loam. If slightly covered with decayed leaves, they will more easily germinate. Large trees are bad to transplant, on account of their main roots extending so far; but if transplanted several times while young, there are few easier.

2. B. LENTA, Linnceus. Leaves cordate, ovate, acuminate, sharply serrate; the nerves beneath hairy, as well as the leafstalks.Sweet black birch. Native of the Northern States.

One of the handsomest of the birches. It is one of the earliest to put out its foliage to welcome the spring. It is generally conically round-headed when old, and frequently has its branches as pendulous as a weeping willow. It will grow sixty or seventy feet high under very favorable circumstances. The Bartram specimen is fifty feet high, three feet ten in. ches in circumference.

Propagated and cultivated as No. 1. 3. B. NIGRA, Linnceus. Leaves rhombic 
ovate, sharp-pointed. Fertile catkins oblong, with hairy scales.-Black birch. Sometimes red birch.

There are several fine specimens at Bartram, which have been styled "paper birches," on account, as I presume, of their shaggy bark. Others, correcting the error, have styled them the B. rubra of Michaux, neither of which I believe are in the collection; nor can I find them really in cultivation in the vicinity.* Our kind is a very ornamental, round-headed, pendulous, branching tree, and thrives best in a rather moist situation. Its white and yellow shaggy bark give it a peculiar character, which interests even in winter.

Propagated and cultivated as No. 1.

4. B. Populifolia, Aiton. Leaves deltoid, much acuminated, unequally serrate. Scale of the fertile catkin, with the middle lobe acute, and smaller than the lateral ones. -American white birch. Poplar birch. The bark of this species is not of so fine a silvery color as the European species. It

* The B. rubra, $M x$. may possibly prove to be the same as $B$. nigra, $L$. 
is a stronger, and makes the finest tree. It thrives best in a cool but not wet loam; but will grow in any dry situation. The best Bartram specimen is forty-one feet high by three feet in circumference.

There is a much finer specimen in Mr. Pierce's arboretum.

Broussonetia, Ventenat.-Nat. Ord. Moraceæ. Diœcia, Tetrandria, Linn. Male flowers in pendulous cylindrical catkins. Female, peduncled, in upright globular heads. Fruit, club-shaped.

B. PAPYRIFERA, Ventenat. Leaves large, downy; some entire, others deeply lobed.Paper-mulberry. Native of Japan.

This tree was formerly in much request for shade. Its wide-spreading branches adapt it well for that purpose. In other respects, it possesses no beauty, and as it throws out many troublesome suckers, it is not now much sought after. It is very apt to be killed by severe winters. It grows to forty or fifty feet high. There are no very large specimens at Bartram, the original trees having been rooted out. In very dry situa- 
tions, where few things will grow, and something is preferred to nothing, the paper-mulberry may be applied to advantage. It also thrives on the sea-shore, as may be seen at Cape May, where it stands solitary and alone as an ornamental tree.

Bumelia, Swartz.-Nat. Ord. Sapotaceæ. Pentandria, Monogynia, Linn. Calyx 5parted. Corolla, with a short tube, 5-parted, with two scales at the base of each segment. Fruit, an ovate, 1-seeded drupe.

B. Lycrordes, Willdenow. Leaves lanceolate, slightly wedge-shaped at the base, and shining. Flowers in axillary panicles.-Bumelia. Native of the Southern States.

A small, thorny tree, of rugged growth, and, in itself, of little beauty. It possesses an interest in the fact of its being nearly evergreen in this vicinity, and is covered with small purple berries in the fall. It will grow pretty well in the deepest shade as well as in open situations, and prefers a rich, loamy soil. It may be propagated by seeds, or more easily by layers. A specimen at 
Bartram is about thirty feet high, and nine inches in diameter.

Buxus, Tournefort.-Nat. Ord. Euphorbiaceæ. Monœcia, Tetrandria, Linn. Calyx of the male flower 3-leaved. Petals 2. Female calyx 4-leaved, with three petals and three styles. Capsules with three beaks. Cells three.

B. SEMPERVIRENS, Linn. Box-tree.

Those who have seen this plant only as an edging to garden-walks, can have no conception of the beauty of the tree varieties. The climate of Philadelphia seems well suited to them. The Bartram specimens, and some at Marshall's, excel anything in beauty I have seen in its native Box-hill in England.

The best Bartram specimen is about thirtysix feet high, and thirty inches in circumference, perfectly symmetrical, and a pair of them (the golden-striped variety) equally uniform. The common green thrives equally well, growing in a gravelly dry soil, under the drip of trees.

It is usually propagated by seeds, layers, or cuttings. The former may be sown as 
soon as ripe, in a cool, somewhat dry and shaded situation. They will readily germinate, and may stay two years where they are sown, then planted out in rows to stay till they are wanted, when they can easily be removed. New varieties may be raised in this way, the box being very apt to sport from seed.

In the nurseries, they are usually raised from cuttings, which root readily when put in a frame of sandy soil early in the fall. The box-tree will transplant at any season, with care. I have been most successful immediately after the breaking up of frost. There are several handsome varieties in cultivation, the broad and narrow-leaved, goldedged, variegated, silver, yellow, and myrtleleaved. The B. Balearica, or Minorca Box, is not, I believe, hardy in Philadelphia.

Carpinus, Linn.-Nat. Ord. Corylaceæ. Monœcia, Polyandria, Linn. Male catkins, cylindrical; scales ovate, acute, ciliate near the base. Stamens twenty; anthers slightly bearded at the top. Female catkins oblong, scales unequally 3-lobed, 1-flowered, perma- 
nent, enlarging, and becoming leafy. Nut ovate, slightly flattened.

C. AMERICANa, Michaux. Leaves oblong ovate, acuminate, unequally serrate.-American hornbean, water-beech. Northern and Middle States.

A small tree, of about twenty-five feet high. Like the birches, it is useful for planting in barren soil, especially if on a clay bottom. It is fond of being near to moisture, as on the margin of streams. It is a very handsome small twiggy tree, the leaves changing in the fall to various shades of crimson, scarlet, and orange, and very often, after they are killed by the frost, are retained on the plant till the spring. The best Bartram specimen is thirty-two feet high, and twenty-six inches in circumference.

It is generally raised in the nurseries by layers; seedlings make finer plants, but are longer in coming on. The seed should be sown as soon as ripe, in a rather moist but light soil, and transplanted when a year old. Unless they are moved à time or two when young, they are difficult of removal afterwards. 
The European hornbean nearly resembles this. The leaves are more perfectly ovate, and each has red ovate glands at its base. There are several varieties of it; propagated by budding on the original, as well as by layers.

Carya, Nuttal.-Nat. Ord. Juglandaceæ. Monœcia, Polyandria, Linn. Male catkins mostly in 3's, with the scales 3-parted. Stamens $3-8$; anthers hairy. Female flowers in clusters, each with one 4-cleft scale, with out any style; the stigma 2-lobed, and each lobe slightly cleft. Nut somewhat quadrangular.

1. C. ALBA, Nuttal. Leaflets mostly three, villous beneath. Fruit depressed, globose; nut flattened. Bark often peeling off in flakes. Shellbark hickory.

This fine tree will not, probably, share the fate of so many other of our fine native trees. In "clearing lots," a "shellbark" or two is generally preserved, in order that its nuts may assist to crack away the tedium of a winter's evening. A place ought to be assigned it 8 
in all new plantations of any extent. Its branches have, in general, a gnarled and twisted appearance, which in winter are exceeded in picturesqueness only by the persimmon, and, in some cases, by the sour-gum and sassafras. When raised from infancy, without being over-crowded, it is rather flatheaded and spreading. It loves a sheltered situation, and thrives best in a rich, rather moist loam. The specimen at Bartram is fifty feet high and three feet in circumference.

It is raised from the nuts sown as soon as ripe, or early in spring, in beds of rich loam, in drills. They should be transplanted after a season's growth. The younger they can be planted where they are to remain the better.

2. C. Amara, Nuttal. Leaflets ovate, smooth on both sides. Fruit nearly round, rather small; shell of the nut very thin; kernel bitter.-Bitter-nut.

With the exception of the peccan, this is the loftiest looking one of the tribe. Its branches all exhibit a desire to grow upwards, and when the tree arrives at maturity, 
the side-branches are frequently the highest parts of the tree.

It thrives best on dry, rocky, or gravelly places. In such situations I have seen it give a peculiarly interesting appearance to the landscape. The foliage is always of a pale yellow tint. It changes to a fine golden yellow in the fall. The finest Bartram specimen is about seventy-five feet high.

For cultivation, \&c. see No. 1.

3. C. oliv arformis, Nuttal. Leaflets numerous, slightly falcate. Fruit, oblong, slightly squared. Nut, olive-shaped, with a smooth, thin shell, often marked with colored lines.Peccan nut. Illinois hickory.

Resembles the bitter-nut in its habits and manner of growth. In a passing glance, it might be taken for an ash; both its trunk and foliage favoring the impression. The finest tree $I$ have seen is at Bartram. It is ninety-one feet high and five and a half feet in circumference. It rarely perfects its fruit in this region, but a young specimen at Bartram often does so.

It thrives well in similar situations to the bitter-nut, and may be managed in the same way. 
4. C. porcina, Nuttal. Leaflets about seven. Fruit pear-shaped, outer shell thin. Nut smooth, slightly compressed, often slightly cordate, hard and smooth.-Pig-nut. This is generally a much smaller tree than the others, and is less picturesque than the shellbark. It thrives best in rather moist situations, and may be propagated as No. 1 .

The finest Bartram specimen is fifty feet high by three feet in circumference.

5. C. tomentosa, Nuttal. Leaves mostly seven. Young leaflets, petioles, and shoots downy. Fruit oval. Nut large, somewhat 6-angled, thick shelled.-Mocker nut. Hickory. This is a well-known tree, but is rapidly disappearing with the forests. I might note many fine specimens in the vicinity, but which, possibly, before this work went to press, might meet the woodman's axe.* A fine specimen exists on the grounds at Spring-

* A remarkable specimen exists in a wood belonging to Miss Ann Bartram, at Kingsessing. I believe it never bears fruit, which may account for its size. One hundred dollars were offered for it as a "liberty-pole" at the election of Gen. Jackson, which the good lady's political principles led her to decline. 
brook, which at least will be preserved so long as its present proprietor has control over it.

Castanea, Tournefort.-Nat. Ord. Corylaceæ. Monœcia, Polyandria, Linn. Male flowers clustered in very long cylindrical catkins. Female flowers generally in threes, within a prickly covering.

1. C. VESCA, Linnoeus. Leaves oblong lanceolate, acuminate, sinuate-serrate, smooth and green on both sides: nuts usually twothree in each covering.-Chestnut-tree. Native of Europe and America. Flowers in June.

Nothing can be a prettier object in the landscape than this well-known tree. It frequently outgrows the oak, which it somewhat resembles in appearance. The foreign varieties, Marroniers of the French, differ in little from our native variety, except in the size of their nuts. They are of distinct importance, however, in a landscape, on account of their remaining green for weeks after our kind has fallen into "the sere and yellow leaf." $8^{*}$ 
It will thrive in the most barren soils, especially those of a rocky or gravelly nature -doing equally as well in a deep, rich loam, or any soil but a wet one. It is, in fact, a tree for any situation. The Bartram specimen is eighty feet high, and seven feet nine inches in circumference; and one of the marrone variety, thirty-five feet high and three feet in circumference.

It may be propagated by seed sown in drills in the spring, or in the fall, if preserved from vermin. The improved varieties are perpetuated by grafting.

2. C. PUMILA, Michaux. Leaves oblong lanceolate, acute, whitish tomentose beneath. -Chinquapin. Native of the Southern States. Flowers in June.

In its wild state, this is but a shrub of meagre stature; but cultivated, makes a pretty, round-headed, miniature chestnut-tree. A specimen at Bartram is twenty-five feet high and thirty-five inches in circumference. There is a very pretty specimen in Mr. Pierce's arboretum, twenty-eight inches in circumference and about thirty-five feet high.

In its native localities, it seems to prefer 
moist situations. Both the specimens above alluded to are in rather dry soil.

It can be propagated as No. 1.

Catalpa, Scopoli.-Nat. Ord. Bignoniacæ. Didynamia Angiosperma, Linn. Calyx 2. parted. Corolla campanulate; limb unequally toothed; tube swollen out. Stamens, two sometimes nearly abortive. Capsule long, cylindrical.

C. BIGNONIOIDES, Walter. Leaves cordate, acuminate, entire, petiolate. Flowers pani culate.-Catalpa. Bean-tree.

This tree sometimes reaches thirty-five or forty feet high, flowering in June, and is, at that time, very ornamental. Yet it is not in much demand. Its leaves are so long in making their appearance in spring, as often to originate the idea that the tree has suffered in the winter. The first cold nights, too, put an end to their verdure, while between its "beans," leaves, and fading flowers, it keeps up a litter throughout the year. Its head is round and regular, while its branches are generally curled and twisted. Its ornamental flowers together, will always insure it a place 
in a collection. The best Bartram specimen is about forty feet high and four feet in circumference.

The catalpa will grow in any soil, but prefers one rather moist. It may be propagated by seeds sown early in spring, in a light loamy soil, a little shaded. Cover them very lightly. They will soon vegetate. The sooner they are planted into the nursery rows the better. They frequently die down a little in winter, but soon lose this weakness. They may also be struck from cuttings of last year's wood, taken off early in the spring, and put in a bed of sandy loam. Strong plants can be raised sooner this way than by seeds.

Cendus, Barrelier.-Nat. Ord. Pinaceæ. Monœecia, Monadelphia, Linn. Differs from Larix in being evergreen, and in the carpels separating from the axis.

1. C. DEODARA, Roxburgh. Leaves in bundles, sharp, somewhat 3-angled, stiff, of a bluish-green, covered with a glaucous bloom. Cones four to five inches long, three to four broad.-Deodar. Native of Nepaul.

This is said to grow one hundred and fifty 
feet high; the largest in this vicinity is not over six. Its light gray color and graceful pendulous habit, gives it a peculiar character which makes it much sought after by ornamental planters. Most of the plants in our nurseries are imported. Such are more readily killed by our winters than plants raised here. The severe winter of 1851-2 killed many of the imported trees in the vicinity of Philadelphia.

I have seen it thrive remarkably well in a cool, sandy loam, and have no doubt of its proving with us one of the most valuable ornamental evergreens.

2. C. LIBANI, Barrelier. Leaves one inch long, nearly cylindrical, tapering to a point, on very short footstalks; growing in tufts. Cones ovate, three to four inches long.-Cedar of Lebanon. Native of Syria.

Of very slow growth in this country. This may arise from imperfect culture. It is very ornamental when of good size. The branches, especially as they grow old, assume a stiffly horizontal direction, and when the tree is in favorable circumstances, sweep the ground. When any way crowded, they soon lose their 
under branches, and present a very artificial looking irregular head. It thrives best in a deep, rich, sandy loam, contiguous to moisture.

The seed should be sown early in the spring, in light, sandy loam, about half an inch deep. They will appear in about six weeks. The following year they may be planted in pots separately, or, which I think preferable, in nursery rows, twelve inches apart. It is well to give them a little protection against frost the first winter or so. Frequently, they are potted and kept in cool frames for a year or two; but, unless under very skilful hands, they are liable to get stunted and be of little use afterwards.

The C. africana, Gordon, from Mount Atlas, is probably but a variety of this with a lighter hue. Its habit and appearance are so nearly alike, that no distinction appears for ornamental uses-so far as I can judge from plants but a few feet high.

Celtis, Tournefort. - Nat. Ord. Ulmaceæ. Polygamia, Monœeia, Linnoeus. Calyx of the staminate flowers 5-parted. Stamens six. Calyx of the perfect flowers 5-parted. Stig- 
ma awl-shaped, elongated, spreading. Styles short, connate.-Fruit drupaceous, 1-seeded, round.

1. C. CRASSIFOLIA, Lamarck. Leaves obliquely cordate ovate, much attenuated, and acuminate, mucronately serrate, very scabrous, and of large size. Flowers appearing before the leaves. Divisions of the calyx spathulate, nearly entire.-Hackberry. Native of the Northern and Middle States.

This fine tree is very little known in our vicinity; and, where it exists, is taken for the next species. There are two specimens (one of each), side by side in the garden of Friend Joshua Hoopes, of West Chester, where the difference between the two can be seen at a glance. And in the garden of Marshall, there is a fine specimen seven feet in circumference, and probably ninety feet high. Its branches spread, and the whole appearance is very much that of an elm; with perhaps a darker hue.*

* Mr. G. W. Emerson, in his "Trees and Shrubs of Massachusetts," observes that this tree "has gnarled, projecting roots, putting out nearly three feet from the surface on every side." 
The berries should be sown as soon as they are ripe. If not sown till spring, they seldom come up till the year following.

2. C. occidentalis, Linnous. Leaves obliquely ovate, serrate, acuminate. Flowers mostly solitary. Divisions of the calyx ciliate. Fruit brownish, not black, as described by Michaux.-American nettle-tree.

When in cultivation, this is a large tree, rivalling some of the elms, which family it more resembles than even the last, often exhibiting the corky barked appearance of some of them. It is not quite so spreading in its habit.

It delights in a moist, rich soil; and, indeed, will become a large tree in no other. The specimens at Bartram being on gravelly soil, and consequently short-lived, are now all dead; but young trees abound.

It is propagated as No. 1.

Cerasus, Jussieu.-Nat. Ord. Drupaceæ, Icosandria, Monogynia, Linn. Drupe globose; nut sub-globose; not covered with a bloom as in the plum.

1. C. CHICASA, Seringe. Branches glabrous, 
becoming rather spiny. Leaves oblong oval, sharp. Flowers on very short peduncles, and mostly in pairs. Calyx glabrous; its lobes very short. Fruit globose, small, yellow, or sometimes red.-Chicasaw plum. Native of the Southern States.

A small, twiggy, erectly-spreading tree, the beauty of which principally lies in its lively shining wood. A specimen at Bartram is twenty-five feet high and thirty-four inches. in circumference.

The best way to propagate is to cut a tree down to a few inches of the ground, making it thus to throw out an abundance of shoots. In the fall following, run a knife just through the bases of each, vertically. Then fill with soil to a few inches over the slit. In the following fall they will be well rooted, and may be taken off the parent.

2. C. Mahaleb, Miller. Leaves somewhat heart-shaped, toothed. Flowers in racemes. Fruit nearly round, black, and very bitterMahaleb cherry. Native of the south of Europe.

The deep black fruit of this tree, and its: small apricot-like foliage, render it a very 
useful tree in ornamental gardening. Its growth is generally erect, though it varies much from seed in this respect. A very fine specimen at Bartram, remarkably spreading and round-headed, is thirty-five feet high and thirty-six inches in circumference. It delights in a deep rich loam, and may be propagated from seeds sown early in spring, or from layers, or the mode given for No. 1.

3. C. Padus, De Candolle. Leaves ovatelanceolate, somewhat thin, sharp, and serrulate, with the teeth rather spreading. Racemes long and leafy. Fruit round.-English bird-eherry. Flowers in April.

A low flat-headed tree, seldom growing aver thirty feet high, but valuable to us for the earliness and beauty of its white flowers. It thrives best in a moist, shady situation; may be propagated as the preceding, or by budding on the $C$. serotina, which improves its vigor. A small specimen at Bartram, in a dry situation, is twenty feet high.

4. C. serotina, De Candolle. Leaves oblong, acuminate, serrate dentate, smooth; the petiole bearing about four glands. Flowers in racemes; petals round. Fruit deep 
red, or purplish.-Wild cherry. Flowers in May.*

Very ornamental, and indispensable in every collection. It is usually round-headed, and, if exposed, throws out its branches to a great distance. Its leaves are of a fine, dark, shining green; and even in winter, when shorn of these beauties, its spotted and speckled branches are interesting. Its fruit is very attractive to birds, thus promoting the pleasures of a country-seat in a twofold manner.

A fine specimen at Bartram is seventy feet high and five feet in circumference.

It will do well in most soils or situations, and is propagated from seeds sown in the spring.

5. C. SYLVEsTRIs, Seringe. Branches vigorous and spreading. Fruit-buds oblong, acute. Flowers in umbels. Variety, flore pleno. Flowers double.-Double-flowering wood-cherry.

* I am indebted to my friend, Dr. W. Darlington, for the observation that the kind known as $C$. Virginiana $\mathrm{L}$. is really this species; the real $C$. Virginiana $L$. being a low shrub. 
Deservedly admired for its pure, white, large, double flowers, appearing in May. Propagated by budding. The Bartram specimen is twenty-five feet high, and thirty-six inches in circumference.

Cercis, Linnoeus.-Nat. Ord. Fabaceæ. Diadelphia, Decandria, Linn. Calyx obtusely 5lobed, gibbous at the base, corolla butterfly. shaped; the wings larger than the standard or top petal. Legume flat, oblong, manyseeded.

1. C. Canadensis, Linnceus. Leaves cordate, nearly round, acute; pubescent in the axils of the nerves beneath.-Red bud. American Judas-tree.

Nothing can be more beautiful in April and May, than a large round-headed "redbud," twenty or thirty feet high, covered with its beautiful flowers before the bursting of a single leaf. The silvery under-surface of the leaves gives the tree a very light hue. I have seen some fine specimens of this in Mr. Pierce's fine avenue. The best Bartram specimen is thirty-five feet high and three feet six inches in circumference, growing in 
a rocky, shady soil, contiguous to moisture.

It is readily raised from seeds sown in the fall, or early in spring, in a cool, shaded loam. They vegetate better if the seeds are sown with the pods, these being merely broken to pieces. They are considered to transplant most easily just before the bursting of the buds.

2. C. Siliquastrum, Linnoeus. Much resembling the other, but with the leaves not so large, or round, and are entirely smooth. The flowers are less brilliant, and the whole tree inferior in beauty. - European Judastree. Native of the south of Europe.

Chionanthus, Linnoeus.-Nat. Ord. Oleaceæ. Diandria, Monogynia, Linn. Calyx 4parted. Corolla 4-5-cleft; lobes very long and slender. Fruit, drupaceous. Nut, striated.

C. Virginica, Linnceus. Leaves ovate, lanceolate, smooth, a little leathery. Peduncles 3-cleft, 3-flowered.-Fringe-tree, flowering in June. Native of the Southern and Middle States.

Though seldom more than a week in 9* 
flower, their beauty, or rather elegance, makes up for their evanescence. They resemble elaborately cut and fringed racemes of white paper. In the fall, its clusters of dark-purple, olive-shaped berries add much to its interest. The tree itself has little beauty; its glaucous hue is frequently mistaken for mildew. It thrives well in a cool, deep loam, and may be propagated by seeds or layers. Seeds should be sown as soon as ripe, in a cool, shaded situation. If not allowed to get too hot or dry, they will vegetate the first season.

The best Bartram specimen is about twenty feet high and thirty inches in circumference.

Connus, Linnaeus.-Nat. Ord. Cornaceæ. Tetrandria, Monogynia, Linn. Petals sessile, 4, valvate in opening. Limb of the calyx very small, 4-toothed. Berry marked by the remains of the calyx. Nut 2-3-celled.

1. C. ALBA, Linnoeus. Leaves broadly ovate, villose beneath. Heads of flowers very flat.White-berried Dogwood. Flowers in May. Native of Russia and North America. 
There are some slight differences between these plants in different localities, but I believe botanists consider them specifically the same. It is a low, spreading tree, becoming in fact but a shrub unless pruned up to a straight stem in its infancy. Its large trusses of white flowers, succeeded by white berries, and the fine red color its branches turn to in winter, render this not the least ornamental of a very handsome tribe of small trees. It is rather scarce near the city, but is in the garden of Mr. John Evans, at Radnor.

It max be propagated by seeds, layers, or grafts. Seeds, if not sown as soon as ripe, often lie two years in the ground; especially if not sown in moist soil. The best plan of raising them, is to take small branches, with several shoots on them, as soon as possible after the frost is out of the ground, and plant them in rows in a rather moist, somewhat shaded place, leaving only the tops of the small shoots out of the soil. It is better not to take off even a leaf. In the following fall most of them will have roots, when they may be taken up and separated to form plants.

2. C. ALternifolia, Linnceus. Leaves 
slightly alternate, oval, heavy underneath. Berries dark purple.-Alternate-leaved dog. wood. Flowers in May, Native of the Northern and Middle States.

This will often grow as large as the $C$. florida, with a similar spreading head. The flowers are of a yellowish-white color, and the wood remains always green. It thrives best in moist shady situations, and may be propagated as No. 1 .

3. C. FLORIDA, Linnoeus. Flowers in capitate clusters, surrounded by four large petallike leaflets, forming an involucre.-Flowery dogwood. American dogwood. Native of the Northern and Middle States.

One of the most beautiful of our native flowering small trees, the flowers appearing in April, and presenting a brilliant appearance. It often grows thirty feet high and one foot in diameter in our forests; but, with them, is fast disappearing. It will thrive in the deepest shade, loves moisture, but does not do well in a dry or exposed situation. The flowers are succeeded by beautiful red berries, and the leaves turn reddish in the fall. The branches grow very horizontal, 
and give it quite an interest in winter, each small twig crowned with its future head of flowers in embryo.

Propagated as No. 1.

The finest Bartram specimen is thirty feet high and two feet nine inches in circumference.

4. C. MAS, Linnceus. Flowers in heads, surrounded by a four-petalled, green, leafy involucre, appearing before the leaves.Cornelian cherry. Native of most parts of Europe.

A round-headed, small, shrubby tree of great beauty, whether considered with regard to its early bee-enticing flowers; its regular, spreading, twiggy head; or the beautiful large red elliptical fruit with which it is covered in the fall. It grows in any soil or situation, but best in a deep rich loam. A specimen at Bartram is fifteen feet high and twelve inches in circumference.

It may be propagated as No. 1 .

Many beautiful varieties might be raised from seed. One with yellow fruit is said already to exist.

5. C. SANGUINEA, Linnceus. Leaves ovate, 
entire, often undulated. Berries black.English red dogwood. Native of Europe. Flowers in June.

The red young shoots give it a brilliant appearance; and the dark berries form a fine contrast. It thrives well in any moist soil. It is much inclined to branch out to form a shrub; when carefully pruned it makes a pretty tree of about fifteen feet high. The best specimens about are in the garden of John Evans.

Cratagus, Linnoeus.-Nat. Ord. Pomaceæ. Icosandria, Di-pentagynia, Linn. Calyx, limb 5-cleft. Petals 5, orbicular, spreading; styles 1-5, smooth. Apple or fruit mealy or fleshy, closed by the teeth of the calyx. Seeds bony.

1. C. Cordata, Miller. Leaves cordate ovate, gashed and cut, smooth; petioles and calyx without glands. Styles 5.-Washing. ton thorn. Maple hawthorn.

All the tribe are highly ornamental small trees, whether considered in flower, fruit, or foliage. The fruit of this is smaller than in most of the following-grows about twenty feet high. All the kinds thrive best in a 
deep rich loam. May be propagated from seeds, layers, or by budding on each other. The seeds very seldom come up the first year. They make finer trees for ornamental purposes by this than by any other mode. For fencing, they are sometimes raised by cuttings of the roots.

2. C. Coccinea, Linnoeus. Leaves cordate ovate, with sharply cut angles, thin and smooth, on long glandular petioles. Styles mostly 5. Fruit large, roundish, bright red. - Scarlet-fruited thorn. American hawthorn.

A very desirable kind, on account of its fine foliage and large fruit.

3. C. CRUS-GALLI, Linnoeus. Leaves nearly sessile, shining, leathery, ovate wedge-shaped, serrate. Segments of the smooth calyx lanceolate. Flowers mostly two-styled.-Cockspur hawthorn. Flowers in May. Native of North America.

The enormous spines, frequently three or four inches long, give this tree its chief peculiarity. The branches spread more horizontally than in some of the others, and are generally of a shining, greenish red. 
4. C. Flava, Aiton. Leaves obovate. Wedge-shaped, angular, smooth and shining. Petioles, stipules, and the segments of the calyx glandular. Berries pear-shaped, yellowish, 4-seeded, branches thorny. Thorns often with small leaves on them.- Yellowfruited hawthorn. Pear-fruited hawthorn. Native of the Northern States. Flowers in May.

A strong-growing, very desirable species; but as yet scarce in cultivation. It is growing in the garden of John Evans.

5. C. OXYACANTHA, Linnceus. Leaves mostly trifid, blunt, a little wedge-shaped, serrate, rather smooth and shining. Petioles and calyx without glands. Styles 1-3. Fruit ovoid.-English hawthorn. Flowers in May.

In England, this is in the smallest garden, so much is it valued for the earliness and fragrance of its flowers. They make very beautiful objects, pruned up to a single stem, as single specimen small trees, in parks and similar places, there; here, they do not seem so well adapted as some of our own species, being of a very luxuriant straggling growth, throwing out few side shoots. There are 
many varieties of this species, of which nearly twenty are cultivated by John Evans, at Radnor. There are also double red and white varieties, and others with variouscolored fruits, highly ornamental.

6. C. PYRIFolia, Aiton. Leaves ovate, elliptic, deeply serrate. Calyx slightly downy. Flowers 3-styled. - Pear-leaved hawthorn.

This species does not grow so tall as some of the other kinds, rarely reaching twenty feet. It is very desirable on account of its foliage, and as being one of the latest to open its blossoms; they seldom appearing before the middle of June. Though a native of the Northern States, it is scarce here in cultivation, Mr. Evans being the only cultivator who, to my knowledge, possesses it.

Cryptomeria, Thunberg. - Nat. Ord. Pinaceæ. Monœcia, Monadelphia. Scales peltate, 4-6-seeded. Seeds 2-winged.

C. JAPONICA, Don. Leaves 5-rowed, sessile, with decurrent nerves, linear, incurved, slightly 4-angled, awl-shaped.-Japan cedar.

In its native country it is said to reach 
near one hundred feet high, growing in damp soils, on a basaltic substratum.

It is perfectly hardy with us, and has a beautiful light-green appearance through summer. In winter it becomes quite brown.

Cupressus, Tournefort. - Nat. Ord. Pinaceæ. Monœcia, Monadelphia, Linn. Male flowers in catkins. Calyx, a scale of the catkin, bearing four sessile anthers. Female flowers heaped in a roundish cone, without a corolla. Styles concave, ovaries eight, in a receptacle. Fruit, a strobile.

1. C. THYoIDES, Linnous. Leaves acute, flat, imbricated.-White cedar. Native of the Middle States.

Frequently grows thirty feet high, and at first sight resembles the red cedar. It has a very slender, straight trunk, and the branches grow erect, giving the tree a very slim appearance. It delights in a low, wet situation, and is therefore often valuable as thriving where few others will. A specimen at Bartram, on rather dry soil, is twenty feet high and nine inches in circumference.

It can be propagated from seeds or cuttings. 
The former sown as soon as ripe, in a light moist soil, in a shady situation. They will mostly appear the following spring.

Cuttings may be taken off in the fall as soon as the wood is firm, and put in a bed of coarse sand, and kept shaded from the full sun. They will require protection from frost, or it will draw them out of the soil. Most of them will be rooted by spring. They are not so desirable for fine specimens as seed. lings.

2. C. Torulosa, David Don. Leaves ovate, obtuse, imbricated in four rows. Main branches crowded, ascending; small branches much crowded, round, closely imbricated with leaves, often recurved at the points.Twisted cypress. Native of Nepaul.

A very beautiful and distinct species.

It does not prove entirely hardy here, but sufficiently so as to demand notice. The finest I have seen in the vicinity is about three feet. It is readily propagated from cuttings, like No. 1.

Crrilla, Linnoeus.-Nat. Ord. Ericaceæ. Pentandria, Monogynia, Linn. Calyx 5- 
parted, persistent, with small divisions. Petals five, thick and convex in the centre, exceeding the length of the calyx. Stamens as long as the petals. Ovary oval, with a short style, and a 2-3 cleft stigma.

1. C. RACEMIFLORA, Linnceus. Leaves wedge-lanceolate, somewhat acute and leathery, smooth. Petals three times longer than the calyx, and convex in the middle.The cyrilla. Native of the Southern States.

One of our prettiest small evergreen trees, whether we consider the cheerful appearance of its foliage, or its beautiful racemes of white flowers. It thrives well in a light, gravelly loam contiguous to moisture. In such, there is a specimen at Bartram twenty feet high and thirty inches in circumference.

Cytisus, Linnceus.-Nat. Ord. Fabaceæ. Calyx 2-lipped. Upper lip 2-cleft. Lower 3 -toothed. Legume attenuated at the base.

C. Laburnum, Linnceus. Racemes simple, pendulous. Leaflets ovate oblong. Legumes many-seeded. - Laburnum. Native of the South of Europe. Flowers in May, in large yellow clusters. 
In the climate of England, this is one of the most ornamental of small trees. It does pretty well here in a deep, rich loam, in a cool, very shaded, but not close or confined situation. It will not do well in a wet soil.

It may be propagated by seeds, layers, or, with care, by cuttings. The former is best. Sow as soon as ripe-if with the pods, the better-early in spring. They appear in a few weeks. The following spring transplant into nursery rows, one foot apart. The sooner they are permanently removed the better, as they get easily checked by being disturbed. There are several varieties, as the oak-leaved, variegated, \&c. These are propagated by grafting or buddings on the common kind.

The best Bartram specimen is about twenty-five feet high by fifteen inches in circumference.

Diospyros, Linnoeus.-Nat. Ord. Ebenaceæ. Polygamia, Diœcia, Linn. Calyx 4-parted. Corolla pitcher-shaped, 4-cleft. Stamens, in the male flower, often sixteen; in the fertile, eight. Styles 4-cleft. Very often 8-seeded. $10 *$ 
D. virginiana, Linnoeus. Leaves ovate, acuminate, entire, nearly smooth; petioles downy; buds smooth.-Persimmon. Native of the Middle and Southern States.

In good soil this will frequently grow forty or fifty feet high, and, in its habits of growth, is one of the most picturesque middle-sized trees we have. When by itself it grows conical, with its branches very tortuose. It is interesting at all seasons. In the spring, by its deep shining green foliage; in the summer, by the light green fruit; in the fall, by the rich orange of its sered leaves, with the deep brown of its fruit; and then in the winter, by its rustically-twisted, "ram's-horn" like branches. It thrives best in a deep rich loam.

It is propagated by its seeds, sown as soon as ripe. They will appear in the spring. It is one of those trees which do not transplant readily, if not carefully cultivated when young.

There is a specimen at Bartram sixty feet high and three feet in circumference; and another fine specimen of a variety planted by William Bartram, which is of a fine flavor long before the frost arrives. 
Elæagnus, Linnous.-Nat. Ord. Elæagnaceæ. Tetrandria, Monogynia, Linn. Calyx tubularly bell-shaped, with four slightly spreading lobes. Stamens shorter than the corolla adhering to its base. Fruit consisting of an achenium, and of the tubular part of the calyx rendered fleshy. The flowers are occasionally male only.

E. HoRTEnsis, Bieberstein. Leaves lanceolate, and, with the shoots of the current year, hoary. Flowers, axillary. Fruit, of a reddish brown.-Oleaster. Native of the south of Europe.

The specimen at Bartram is about twentyfive feet high and twelve inches in circumference. It is a small willow-like tree, with a soft mellow-looking foliage, keeping green, in our specimen, till near Christmas.

It is easily propagated from its berries, sown as soon as ripe; or by layers. It does best in a loose loamy soil, and prefers a cool situation.

Euonymus, Tournefort.-Nat. Ord. Celastraceæ. Pentandria, Monogynia, Linn. Fruit capsular, 3-5-angled; 3-5-valved; valves 
opening by the middle. Seeds coated by a colored arillus.

1. E. Atropurpureus, Jacquin. Leaves elliptic ovate, acuminate, petiolate. Capsules smooth.-Dark purple spindle-tree. Native of the Middle States.

Under very favorable circumstances, and with good trimming when young, it will make a small tree of fifteen feet high; otherwise it will scarcely come under the head of Arboriculture. Its red capsules render it very conspicuous in the fall.

It thrives best in a deep rich loam, in a somewhat shaded situation. It is readily propagated by either seeds, or layers. Seeds should be sown as soon as ripe, or they will not germinate for a season. They will come up freely if sown in any moist, shady place.

The best specimen at Bartram, on stony soil, is about ten feet high.

2. E. EURoPGUS, Linnceus. Leaves smooth, bluntly serrate, elliptical; flowers mostly 4-stamened; peduncles compressed, manyflowered. Stigmas awl-shaped. Angles of the capsules blunt.-European spindle-tree. Those who have seen this tree in English 
gardens, about ten or fifteen feet high, would be unprepared to see a specimen double this size in the garden of friend Longstreth, Kingsessing, which was probably planted there by Young, "the King's Botanist," and rival of John Bartram, who formerly owned the place. Its gray bark, and, in the fall, its pale pink capsules, clothe it with interest.

It may be propagated as No. 1 .

3. E. LATIFolius, Bauhin. Leaves serrate, lanceolate, with short petioles. Flowers mostly 5-stamened, on long cylindrical pedicels, many together. Petals white, changing to purple. Angles of the capsules sharp.Broad-leaved spindle-tree.

This is a finer species than either of the other two, growing much larger and stronger, and having finer foliage and larger fruit. It is scarce in these parts, but is cultivated in the garden of John Evans.

It is a native of the south of Europe.

Fagus, Linnous.-Nat. Ord. Corylaceæ. Monœcia, Polyandria, Linn. Staminate flowers numerous; in globose, pedunculate, pendulous catkins. Female flowers in twos, in an 
ovoidal, muricated involucre. Pistil with the base covered by the calyx. Styles three, awl-shaped. Nut triangular.

1. F. Ferruginea, Aiton. Leaves oblong ovate, acuminate, more or less dentate, ciliate; the flexible armature, or bracts, of the involucre spreading, or recurved.-American beech.

Who does not know the beech? From the child who cuts its name on the smooth gray bark, to the aged one who stops, leaning on his staff, to take an oft-repeated look at some noble specimen in a landscape. It looks well in any situation where quietness and graceful elegance are sought to be expressed. In wild or rugged scenery, I consider it out of place. By itself, in a quiet, sheltered nook, in a deep rich loam, it will form an object not easily surpassed for beauty. Its deep green glossy foliage; its slender feathery branches; the silvery gray of its trunk, with its robust, ample proportions, cannot fail to excite admiration. In wild, rugged scenery, its foliage seems too dense for its light branches; and the head is too regular, and seeming too overgrown to be in 
keeping. It will often grow to a very large size in rocky soil, if not too dry. Its roots extend a long way, and so near the surface that nothing but a kind of broom-rape, which nature seems wisely to have provided for the purpose, will grow amongst them. The best Bartram specimen is about seventy-two feet high and four feet four inches in circum. ference.

Seeds sown early in spring very soon germinate. They should be early transplanted to nursery-rows, and have plenty of room allowed them. For permanent situations, a two-year old plant is better than an older one.

2. F. Sylvatica, Linnoeus. Leaves ovate, glabrous, slightly toothed, and ciliated.-European beech.

This very much resembles our species in habit, but has a glossier-looking foliage, and more compact habit of growth. It is very scarce in our district, existing chiefly as stocks on which imported varieties have been grafted, and failed. It is very late in budding out in the spring.

The variety cuprea is more common. The 
most handsome in form is probably that at Bartram, which is clothed with branches to the ground, and is fifty feet high and thirtysix inches in circumference. A specimen with a magnificent head exists in the fine arboretum of Mr. Pierce, which is five feet in circumference. It is propagated by grafting the two-year old wood on the original species.

The var. sanguinea has larger and darkercolored foliage. I have seen no very large specimens here.

Var. pendula is a fine weeping variety, propagated also by grafting.

The var. laciniata is cultivated in the "Woodlands" west of the Schuylkill. Its finely cut foliage gives it a very distinct appearance.

Small specimens of the var. cristata are also in cultivation, the leaves appearing like a curled willow.

Fraxinus, Tournefort.-Nat. Ord. Oleaceæ. Polygamia, Diøcia, Linn. Sometimes Diandria Monogynia. Calyx mostly none, or 4parted. Corolla none, or 4-petalled. Stamens 
mostly 2. Pistil one. Capsule a flat, lanceolate, winged samara.

1. F. AMERICANa, Linnours. Leaflets oblong ovate, somewhat pubescent and glaucous beneath; petioles and young branches smooth. Also $F$. acuminata, Lambert.-White ash. What the Quercus alba is to its family, this is to the ashes-the chief. It is one of our prettiest trees. The head is flat when the tree is full grown, and when seen at a little distance, seems regularly marked with horizontal lines of light and shade. Its hue is so light as to have a beautiful effect when combined with trees of a darker shade. One of the prettiest combinations of trees I think I ever saw had a white ash with an European linden on each side; not near enough to touch each other. The lindens were perfect cones, and perhaps one-third taller than the ash ; and formed a fine contrast, both in habit and color, to the ash. There was a splendid specimen at Bartram, which blew down in a gale in 1850, measuring over one hundred feet high. The roots of all the ashes run very near to the surface. They require a rich loam and plenty of room to arrive at 
perfection. Seeds should be sown as soon as ripe, on a bed of sandy loam, in a rather moist situation. They will come up in the spring. They should be transplanted into nursery rooms, at least two feet apart, at the end of the first season's growth. All the ashes are amongst the latest to push forth in the spring.

2. F. EPIPTERA, Willdenow, which is included in many of our collections and catalogues, is, so far as I have been enabled to determine, either the same thing as $F$. Americana, $L$. or is not really with us.

3. F. EXCELSIOR, Willdenow. Leaflets lanceolate, serrate, sessile. Flowers without petals.-English ash.

This species, though resembling the black ash in its descriptive character, is readily distinguished at sight. Its leaflets are smaller, and but 4-6 in a leaf. The hue of the foliage is so light as to make a marked distinction. A very fine specimen existed at Bartram till 1851, when, being very nearly decayed, it was taken down. There are still several small ones, some exceeding thirty feet high.

For soil and cultivation see No. 1 . 
Var. aurea has an interesting appearance, from the color of its bark. There is a fairsized specimen on the grounds of Mr. R. Buist, Rosedale, Kingsessing.

Var. heterophylla, often bearing entire leaves, grows in the garden of John Evans.

Var. pendula, the weeping ash, is indispensable in many situations. There is a very interesting specimen at Bartram, forming the "Washington arbor" under which the Father of his country, Benjamin Franklin, Wilson, and other eminent men, have often sat; and wherein, surrounded by scenes he loved, William Bartram breathed his last. Here sat Washington, when he replied to the French ambassador's playful inquiry, what kind of a nut that (bombshell) was: "It is a nut too hard for John Bull to crack." There is another taller specimen on the same grounds.

It is propagated by budding on any of the strong-growing species.

4. F. Juglandifolia, Willdenow. Leaflets 7-toothed, petiolate, oval acuminate. Branches and petioles smooth.-Walnut-leaved ash. Native of the Middle and Southern States.

A middle-sized tree, attaining sometimes 
sixty feet high. It thrives best in a cool deep loam, contiguous to moisture.

5. F. PUBESCENS, Walter. Leaflets on short petioles, elliptic lanceolate, slightly sharp and serrate; petioles and young branches downy. -Downy ash. Red ash. Native of the Northern and Middle States.

The most irregular-headed of all the ashes. The branches are frequently twisted and tortuose, very different to the stiffness so general in the tribe; though not attaining such large proportions as some other kinds, it is more ornamental. It thrives best in a moist situation. A fine specimen at Bartram is fifty feet high by five feet two inches in circumference.

6. F. Quadrangulata, Michaux. Young branches quadrangular, nearly sessile, oval lanceolate, sharply serrate, downy beneath.Blue ash. Native of the Western States.

I have seen but one small tree, in the arboretum of Mr. Pierce. It has the appearance of being very ornamental. It is said to grow sixty or seventy feet high, and to require less moisture than most of our other species.

7. F. sambucifolia, Willdenow. Leaflets 
ovate lanceolate, sessile; the midrib hairy beneath. Calyx wanting.-Black ash. Native of the Northern and Middle States.

As an ornamental tree, this possesses few points of interest. It has a coarse formal habit, pushes forth its leaves late in spring, and sheds them early in fall, and when leafless, has no point of beauty beyond a dingy, smoky, disagreeable blackness, which may occasionally please by its evident harmony with wintriness and dulness. It prefers a moist situation.

Gleditschia, Linnoeus.-Nat. Ord. Fabaceæ. Polygamia, Diœcia, Linn. Hermaphrodite flowers with a 4-cleft calyx. Corolla 4petalled. Stamens 6. Pistil 1.-Male calyx 3-leaved. Corolla 3-petalled.-Female calyx 5-leaved, corolla 5-petalled.

1. G. TRIACANthos, Linnceus. Leaflets ovate oblong. Frequently, very spiny. Spines axillary.-Honey locust.

The most usual height is fifty feet. Opinions are divided in regard to the value of this tree in the landscape. When in fruit, with its large bean-like pods, it has a pleasing aspect. 
Its formidable-looking spines and extremely thin foliage, detract from its otherwise agreeable appearance.

In spite of its many defects, its place in some situations cannot be better supplied. There is a fine specimen at Bartram, but the winds have made sad havoc with it. It is ninety feet high and eight feet in circumference. It thrives best in a deep rich loam, and is readily propagated from seed sown early in the spring.

Gordonia, Ellis.-Nat. Ord. Ternströmiaceæ. Monadelphia, Polyandria, Linn. Calyx of 5-sepals, permanent. Petals 5, slightly united at the base. Style short, crowned by a 5-cornered peltate stigma. Capsules 5-celled, 5 -valved.

1. G. Lasianthus, Linnceus. Leaves very smooth, stiff, and shining, slightly serrate. Flowers on long peduncles. Capsule somewhat conical, tapering at the top.-Loblolly bay. Native of the Southern States.

I am not sure I am right in including this tree as being in our neighborhood. The Bartram specimens have died out. I copy 
the following description from Michaux: "The leaves are evergreen, from three to six inches long, alternate, oval, acuminate, slightly toothed, and smooth and shining on the upper surface. The flowers are more than an inch broad, white and sweet-scented. They begin to appear about the middle of July, and bloom in succession during two or three months. This tree possesses the agreeable singularity of blooming when only three or four feet high. From twenty-five to thirty feet of its trunk is perfectly straight. The small divergency of its branches near the trunk, give it a regular pyramidal form; but as they ascend they spread more loosely, like other trees of the forest." "The seed germinate succesfully in wet places among sphagnum moss."

2. Gordonia PUBESCENs, Willdenow. Leaves lanceolate, slightly downy and serrate. Flowers sessile, capsule round. Franklinia of Marshal-Franklin-tree. Banks of the Altahama, Georgia.

In the Bartram garden this tree grows to about thirty feet high, and has a diameter of from nine to twelve inches. The finest specimen lately blew off in a gale. It has a very 
erect habit of growth, and is very much inclined to throw out small branchlets to its base. The flowers, which are white, like a single camellia, and sweet-scented, appear at the ends of the young branches, continuing from July till frost. It seems to thrive best in a light rich loam, contiguous to moisture; and may be propagated by either seeds or layers.

Gymnocladus, Lamarck.-Nat. Ord. Fabaceæ. Diøcia, Decandria, Linn. Corolla of 5 equal petals. Fruit a broad flattened legume. Seeds roundish.

G. CANADENSIS, Lamarck. Leaves doubly pinnate.-Kentucky coffee.

A tree of noble proportions; with a reddish-gray, straight trunk, and heavy luxuriant-looking foliage. Denuded of its leaves by the frost, its branches still interest by their crooked, picturesque appearance, an interest sometimes heightened by the large seed-pods, which stay on till spring.

It thrives well in a loose loam, which, if deep, will grow it to a great size. The best specimen at Bartram is ninety-three feet high 
and six feet in circumference. There is also a very fine specimen in Marshall's garden, which is probably as high, and seven feet in circumference.

It is raised from seeds or by cuttings of the roots. The former are sown early in the spring. The latter method is most generally adopted. The roots are cut into lengths of two or three inches, planted in boxes with the largest end even with the surface, about the end of the winter season, and the boxes placed in a slight bottom heat. When the cuttings are rooted, they are put out in nursery rows, and after their first season's growth, are cut down to a few inches of the ground, when they spring up afresh with a vigorous start.

Halesia, Ellis.-Nat. Ord. Styracaceæ. Dodecandria, or Monadelphia, Monogynia, Linn. Calyx 4-toothed, superior, corolla 4cleft, twisted to the left. Nut winged; 2seeded.

1. H. DIPTERA, Linnceus. Leaves ovate, petioles smooth and even. Fruit with two large and two small wings.-Two-winged Halesia. Native of Georgia. 
Is not easily distinguished from H. tetraptera when young. A close attention to the leaves will enable one to distinguish them. When in flower or fruit the distinction is striking. It does not grow so large as the other kind, but the flowers are handsomer.

It may be raised from seeds, or by grafting on the tetraptera. Seeds should be sown, as soon as they are ripe, in a light loam. They must never be allowed to get dry, or they will not appear till the following year. It thrives best in a cool deep loam. A specimen at Bartram in dry gravel is about fifteen feet high and nine inches in circumference.

2. H. Tetraptera, Linnouus. Leaves ovate, petioles glandular. Nut 4-winged.-Snowdrop tree. Native of the Southern States. Flowers in April.

The tree is round-headed, somewhat pendulous and irregular, very light and twiggy; when covered with its white flowers it is very ornamental. The best Bartram specimen is fifty feet high and three feet six inches in circumference. It will do pretty well in any dry soil, but best in a deep rich loam. It is easily propagated by seeds, as No. 1 . 
Hamamelis, Linnoeus.-Nat. Ord. Hamamelidaceæ. Tetrandria, Digynia, Linn. Often monœcious, dicecious, or polygamous. Calyx 3-4-leaved. Petals 4. Stamens 8, 4 sterile. Ovary ending in 2-3 styles at the apex. Capsules leathery, 2-celled, throwing the seeds to a distance on bursting.

1. H. VIRGINICA, Linnoeus. Leaves roundish ovate, sharply toothed, alternate.-Witch hazel. Native of the Middle States.

Naturally but a shrub, but a handsome small tree in cultivation. It sends out its yellowish small flowers immediately after the fall of the leaf; the fruit of the previous season ripening at the same time. The foliage much resembles that of the hazel. It seems to thrive well in any situation, whether dry or moist, stony or clayey; in exposed situations or the deepest shade. The best specimen of Bartram is about fifteen feet high and ten inches in circumference. It may be raised from seeds or layers. The former generally lie in the ground two years before they grow.

Hibiscus, Linnoeus.-Nat. Ord. Malvaceæ. Monadelphia, Polyandria, Linn. Involucre 
of many bracts, inner one nearly entire. Styles united. Stigmas 5-10-headed. Capsule 5-10-celled.

H. SyRIACUS, Linnoeus. Leaves ovate, wedge-shaped, deeply cut.-Althæa frutex. Native of Syria.

A well-known small tree, although it is most commonly seen as a shrub. Its flowers constitute its chief value. These are of every shade of color, even to the yellow, though that variety is now scarce. It does best in a deep rich loam, and will do well in any soil but a wet one. It is best propagated from seeds sown in spring, which will soon come up and make good plants. They will also do pretty well by cuttings put in early in spring in light soil, in a warm yet somewhat shaded situation. By layers they do very well.

Fine specimens, from fifteen to twenty feet high, are common in the vicinity.

HippopHa, Linnceus.-Nat. Ord. Eleagnaceæ. Diœcia, Tetrandria, Linn. Barren flowers in catkins. Anthers linear, without filaments. Fertile flowers solitary. Calyx tubular, 
cloven at the summit. Stigma awl-shaped. Nut one-seeded, surrounded by a berry-like calyx.

H. RHAMNOIDES, Linn. Leaves linear lanceolate, silvery. Berry orange.-Sea buckthorn. Native of Europe. Flowers in May.

A bumelia-like small tree, well worthy of cultivation either for its beautiful foliage or its berries. It will thrive in the most barren soils. It is readily propagated from layers or from suckers, which in some soils are so numerous as to be troublesome. There is a specimen about three feet high growing in the garden of John Evans.

Itex, Linn.-Nat. Ord. Aquifoliaceæ. Tetrandria, Tetragynia, Linn. Flowers (from abortion) diœciously polygamous. Calyx 45-toothed, remaining attached to the fruit. Petals of the corolla equal in number to the sepals of the calyx; slightly adhering at the base. Berry 4-5-seeded.

1. I. AQUIFolium, Linn. Leaves ovate, acute, spiny, shining, wavy. Flowers axillary, subumbelled.-English holly. 
In Britain, this rises forty feet high, or more. It is one of the handsomest evergreens. It is considered scarcely hardy in Philadelphia. In the very severe winter of 1851-2, a specimen at Springbrook, grafted on the I. opaca, came out uninjured, while another close by on its own roots suffered very much. It prefers a cool deep loam, and a situation shaded from our hot suns. It is rather difficult to transplant, unless it has been frequently removed already. I prefer the month of May for the operation, taking advantage of some rainy "spell" for that purpose. They will often do well removed in August or September.

It may be propagated by seeds. These are generally put into a heap of sand to ferment together for twelve months. If sown as soon as gathered, they lie two years in the ground before germination. They ought to be transplanted at the end of the first season's growth, and great care afterwards taken to prevent their getting dry. If they once lose their leaves, they are not easily recovered. It may also be grafted on No. 2 in March or April, or budded in August or 
September. Buds take best on two year old wood.

There are several beautiful varieties introduced, as well as many others that deserve to be. Amongst the former are the ferox, having its leaves a nest of spiny bristles; the golden-leaved, and silver-edged. The old catalogues of foreign nurserymen reckon over forty varieties.

2. I. OPACA, Aiton. Leaves ovate, acute, flat, smooth, spiny. Flowers at the base of last season's shoots.-American holly. Native of the Middle and Southern States.

It is rather nice in its choice of soils, refusing unconditionally to "do good" in cold, wet, or clayey ones. In a deep rich loam it can scarcely be excelled by any evergreen I know; and it will grow in dry or barren places. It is seldom of so dark a hue as No. 1; but that contrasts as well with its light-red berries. The best Bartram specimen is thirty-two feet high, by forty inches in circumference at the base.

Propagation. See No. 1.

3. I. vomitoria, Aiton. Leaves alternate, distant, oblong, somewhat blunt, serrate, not 
spiny.-Emetic holly; South Sea tea. Native of the Southern States.

A very beautiful small evergreen tree, rising from fifteen to eighteen feet high, of a pyramidal form, with very dark green foliage, and clothed with beautiful red berries throughout the winter. It is scarcely considered hardy here, though I believe in most cases it is so.

Juguans, Linn.-Nat. Ord. Juglandaceæ. Monœeia, Polyandria, Linn. Catkins of the staminate flowers simple, cylindrical, loosely imbricated, with a 5-6-parted scale for a calyx. Styles two, very short, with large stigmas. Fruit with the husk undivided.

1. J. CINEREA, Linn. Leaflets mostly eleven, oblong lanceolate, oblique or roundish at the base, softly pubescent beneath; petioles downy. Fruit ovoid, oblong, leathery, downy, sticky, or viscid, and the shell of the nut deeply striated.-Butternut; white walnut. Native of most of the Northern, Middle, and Western States.

The ailanthus has been admired for its "oriental" appearance in the landscape. As 
it is fast growing in disgrace, this tribe is the best substitute. This kind seldom exceeds fifty feet high, is generally round-headed, with an inclination to become flat. The finest specimen at Bartram is fifty-five feet high and fifty-four inches in circumference.

It thrives best in a cool, deep, and rich loam; and is best propagated by sowing the nuts about four inches apart, in rows, early in spring, covering them about two inches deep. They are in general difficult to transplant, and the sooner they are removed to their final positions the better. They also take easily by grafting on each other.

2. J. NIGRA, Linnoeus. Leaflets about fifteen, ovate lanceolate, nearly heart-shaped at the base. Fruit globose, dotted, spongy. Nut nearly round, wrinkled.-Black walnut.

This is a larger tree every way than the preceding, and the handsomest of the group. It is somewhat round-headed, but frequently quite cylindrical, or even conical. They should always grow by themselves, on account of their unneighborly propensity of injuring everything growing about them. The finest Bartram specimen is eighty feet 
high by four feet ten inches in circumference.

The same soil and culture as No. 1 suits it also.

3. J. REGIA, Linnous. Leaflets about nine, oval or oblong, smooth. Fruit ovate, smooth. Nut with a thin shell.--English walnut.

Not quite so ornamental as either of the other two; but still interesting on account of its luxuriant growth, fine glossy foliage, deep purple branches, and smooth gray stems. When old, it is round-headed, often flat, and, to most tastes, less interesting. It loves a deep, dry, rich loam, especially if it have a limestone character. There are many fine specimens about'Philadelphia. The Bartram specimen is but young, but measures forty feet high, and thirty-four inches in circumference. The female flowers are frequently killed by spring frosts.

Propagated by sowing the nuts, or by grafting.

Juniperus, Linnceus. -Nat. Ord. Pinaceæ. Diœcia, Monadelphia, Linn. Male flower a conical catkin; the scales of the catkin each 
forming a calyx. Stamens three. Female, calyx 3-parted. Petals three. Styles three. Berry 3 -seeded, irregular.

1. J. communis, Linnoeus. Leaves in threes, spreading, mucronate. Berries longish.Common juniper. Native of Europe and America.

When usually seen in gardens, it is but a shrub, tied up into shapes pyramidal and conical; when left to itself, without the inter. ference of knife or string, it forms a very picturesque small tree. There is such a specimen at Bartram, measuring thirty-five feet high, and two and a half feet in circum. ference. It is growing on a dry loam with a gravelly subsoil, which seems to suit it admirably. There are several varieties, amongst which I am inclined to include the Swedish juniper, J. suecica, Miller.

They may be easily raised from seed sown as soon as ripe; or by cuttings put in sandy soil early in the fall, and protected from frost through the winter.

2. J. EXCELSA of Bieberstein. A Siberian species, with a fine erect habit of growth and glaucous foliage; ought to be hardy in this 
district; but, so far as I have hitherto seen, has been preserved in cool greenhouses in the winter.

3. J. virginiana, Linnoeus. Leaves in threes, fastened at the base; the younger ones imbricate, the older spreading. Berries roundish.-Red cedar.

A well-known and useful evergreen, often growing thirty or forty feet high. It varies so much from seed, that to describe its habits of growth, would be to particularize each individual tree. Sometimes compact, sometimes very loose; in one case erect and stiff, in another gracefully pendent. In, some places, we see them broadly round-headed, in others spiry and conical. The handsomest young specimen I have ever seen is in $\mathrm{Mr}$. Beckett's (formerly Buonaparte's) grounds, at Bordentown; and with the finest trunk, on the grounds of Mr. Cope. The red cedar thrives in any dry loose soil that is not too rich, but seems to do best in a light cool loam.

It is readily propagated like No. 1. 
Kelreuteria, Laxmann.-Nat. Ord. Sapindaceæ. Octandria, Monogynia, Linn. Calyx 5-parted. Petals mostly 4, with a double appendage on the inside. Style acute at the apex. Fruit bladdery, 1-celled above, 3celled below, 3-valved. Leaves alternate.

K. PANICULATA, Lambert. The only known species. Native of China.

A very pretty looking small tree, deserving a place in every garden for its numerous large panicles of yellow flowers, with which the tree is covered in July and August. A cool deep loam, in a situation partially shaded, is well suited to it. In England, it is propagated from layers and root cuttings. In this country it perfects its seed. The specimen at Bartram is below the average, being about fifteen feet.

Lagerstramia, Linnceus.-Nat. Ord. Lythraceæ. Polyandria, Monogynia, Linn. Calyx 6-cleft, bell-shaped. Petals 6, curled. Stamens with the six outer ones stouter than the rest, and longer than the petals.

L. REGINA, Roxburgh. Leaves opposite. 
Lagerstræmia.-Fringe myrtle. Native of the mountains of the East Indies.

A very beautiful small tree, generally treated as a greenhouse plant. A fine specimen on the grounds of the late Nathan Jones, Blockley, near Philadelphia, planted many years ago by one of the Bartrams, is now over thirty feet high, and, when in flower, is a most beautiful sight. This is growing in a light poor soil. It is sheltered on the north-west by the house from wintry winds, and partially shaded from the hot sun by trees on the south. In cold clays it is generally cut to the ground in winter.

It is propagated by cuttings or layers. The former should be taken off just before the fall of the leaf, and placed in sandy soil, where they can be protected from frost during winter, and not suffered to get damp.

LARIX, Tournefort.-Nat. Ord. Pinaceæ. Monœcia, Monadelphia, Linn., or Diœcia. Leaves annual, disposed in groups. Cones erect.

1. L. europea, Decandolle. Leaves linear, soft, one inch long. Cones oblong, ovate, 
erect, one inch long.-European larch. Mountains of Europe.

In ornamental gardening, few trees come into service oftener than the larch. It has become so associated with rocky, rugged, barren scenery, that wherever this is prominent we almost look for the larch as for a necessity. Its foliage is of such an agreeable light-green hue, and at the same time so soft and graceful, while its branches are frequently drooping and always slender, that it is sure to please. It has the advantage, too, of thriving in the dryest and most barren soils, where little else will, and thereby turning a useless piece of ground into a source of pleasure and profit. There are several fine specimens both at Bartram and in Marshall's. The finest of the former is one hundred and eight feet high, and five feet four inches in circumference.

The seed should be sown early in spring in boxes of light sandy soil, or in beds of the same material; cover about a quarter of an inch thick, and keep them carefully moist till the plants appear. If sown thinly, they 
will be better not transplanted for a couple of years.

2. L. AMERICANA, Michaux. Leaves about three-quarters of an inch long. Cones small, ovate roundish, with few scales.-American larch; hackmatack.

Though closely allied botanically with No. 1 , it is very different in general appearance. The foliage has a bluish tinge, the branches less drooping, and more divaricating.

In a level piece of ground, standing singly, I think it more beautiful than the other. It thrives best in a deep cool loam, and in a rather moist situation, and may be propagated as No. 1.

The best Bartram specimen is quite young, but is about forty feet high and two feet nine inches in circumference.

Laurus, Linnceus.-Nat. Ord. Lauraceæ. Enneandria, Monogynia, Linn. Calyx wanting. Corolla 6-parted. Stamens arranged in a double series, the outer ones with distinct simple filaments, the three inner ones connate at the base, bearing glands. Fruit a one-seeded drupe. 
L. SASSAFRAS, Linnous. Leaves entire or 3-lobed. Flowers terminal, frequently diœcious. Buds and pedicels downy.-Sassafras.

In my opinion, one of the most interesting trees that can be in a landscape, the glaucous green of its foliage is so uncommon; and it is one of the first to aid in forming that beautiful picture of autumnal forest scenery which has so enraptured European travellers, and gives the American landscape a position amongst the special beauties of the world. The sassafras generally grows in a conical form; but the leaves are mostly formed on the branches in lines running horizontally, causing a very pleasing effect in light and shade. Towards the fall, the leaves turn to a reddish-brown, turning up at the edges, with a beautiful appearance. Unfortunately, nature seldom gives her beauties unalloyed; and, in the case before us, the suckers which it perseveringly throws up in spite of all opposition, render it objectionable. It is readily propagated from suckers, or by seeds sown in June, as soon as ripe. It thrives well in dry sandy loam, but will grow in any situation. The best Bartram specimen is 
fifty feet high and forty-two inches in circumference.

Liquidambar, Linnous.-Nat. Ord. Altingiaceæ. Monœcia, polyandria, Linn. Male flower with a common 4-leaved calyx, without a corolla. Female calyx in a globe, 4leaved, without a corolla. Styles 2. Capsules many, in a globe, 2-valved, many seeded.

L. STYRACIFLUA, Linnoeus. Leaves palmate-lobed, with the sinuses of the base of the veins villose.- Sweet gum. Native of the Middle States.

This varies very much according to the circumstance or situation wherein it grows. In the shade, or surrounded by other trees, it has very few side branches, and grows up with a clean smooth stem to a great height. In a wet soil, but in an exposed situation, it grows tall, with a very bulky trunk, and a loose cylindrical appearance. In a cool, deep, rich loam, it becomes very spreading and round-headed, and in that state is one of the prettiest of trees. Its star-like cut leaves, with their beautiful gloss, move, like some poplars, with the lightest breezes; and, ex- 
posed to the full sun, give animation to scenery. Its branches frequently present a curious corky appearance. In favorable circumstances I have known it grow eighty feet high, with a circumference of seven feet. The Bartram specimen, on dry stony soil, is nearly decayed, and is forty-five feet high, and four and a half feet in circumference. It is raised from seeds, sown as soon as ripe in a light loam, in a cool situation, slightly protected in winter by a few leaves thrown over the bed. Most of them will appear in the following spring.

Liriodendron, Linnceus.-Nat. Ord. Magnoliaceæ. Polyandria, Polygynia, Linn. Carpels not opening to let out the seed, as in Magnolia; winged, arranged in a spike. Calyx 3-leaved, deciduous. Corolla 6-petalled, bell-shaped.

L. TULIPIFERA, Linnceus. Leaves 3-lobed, the terminal lobe appearing as if abruptly cut off.-Tulip-tree. Native of the Northern and Middle States. Flowers in June.

One of the loftiest of American deciduous trees. It rises with a stem perfectly straight; 
and, when crowded, soon loses its sidebranches. When the tree becomes old, the main branches curve downwards, affording a readily distinguishing mark when it is destitute of foliage. When unsurrounded by any other tree, it branches out close to the ground, and presents a fine conical appearance till it gets old, when it becomes, rather irregular and rough in its appearance. Few trees are better fitted to form a single object in a park or on a lawn; the very peculiarity of its foliage and appearance suggesting the exclusiveness in which it would stand in order to show off its entire beauty. It is shortlived in towns, and soon shows a distaste for city life; evidently preferring the times of the Indians to the modern march of civilization. It thrives best in strong, clayey, or micaceous soils. They are easily raised from seed, sown as soon as ripe, in any loamy soil in a shady situation. They will appear the next spring. They should be transplanted every year till they go into their permanent situations, as, otherwise, it is next to impossible to remove them successfully. The finest specimen I am acquainted with in cul- 
tivation is at Bartram, which is ninety feet high and seven feet eight inches in circumference.

Maclura, Nuttall. - Nat. Ord. Moraceæ. Diœcia, Tetrandria, Linn. Male flowers in a very short, nearly sessile panicle of about twelve flowers. Female flowers in close heads on a short peduncle.

M. aurantiaca, Nuttall. Leaves ovate acuminate, of a deep shining green. Male plant with smaller leaves. Fruit as large as a good-sized orange, golden yellow, verrucose.-Osange orange. Native of Arkansas.

As an ornamental tree, this is almost too coarse to be beautiful; yet its shining leaves, and pretty fruit, will always insure it a place in collections. The best Bartram specimen (female) is about thirty feet high and four feet in circumference. The male about fifteen feet high. It is best propagated from seeds obtained from the neighborhood of a staminate plant, and sown in drills like peas early in the spring; the following year place in nursery-rows eighteen inches apart. 
It prefers a rich moist loam, though it will grow in any situation.

Magnolia, Linnoeus.-Nat. Ord. Magnoliaceæ. Polyandria, Polygynia, Linn. Calyx 3leaved. Petals 9. Carpels collected generally in a crowded spike, each opening by the external surface; 1-2-seeded. Seeds berry-like, hanging from the carpels by threads when ripe.

1. M. acuminata, Linnoeus. Leaves ovate, tapering to a point. Fruit cylindrical, resembling, before ripe, a small cucumber.-Blue magnolia; cucumber-tree.

Cultivated, this is the finest of the family. In common with all the deciduous magnolias, this is very artificial in its appearance, and well. adapted on that account to many peculiar situations in a garden. The fine specimens at Bartram are rather round or flattish-headed, having lost their lower branches; but the specimens in Marshall's garden are of the most beautiful and regular conical shape. Having no leaves but at the extremities, we look up into this specimen as to an immense umbrella. This is about 
ninety years old, and is seven feet ten inches in circumference, and perhaps eighty feet high. The Bartram one is about the same height, and but seven feet in circumference. It is a native of the mountainous regions of the Middle States, and thrives well in any deep loam on a dry bottom.

They are very easily propagated by seeds sown as soon as ripe. They require early transplanting to their final positions; or, otherwise, frequently removed. They take readily grafted on each other.

2. M. AURICUlata, Lamarck. Leaves ovate, narrowed towards the base, and swelling out into lobes or ears. Fruit smaller than $M$. $m a$ crophylla.-Long-leaved cucumber-tree. Native of the Middle States. Flowers in May.

This seems to excel in cultivation anything in a wild state. It is perhaps more artificial in its character than the last, as it has larger leaves and denser foliage, of a paler hue, contrasting well with the depth of its own shade. Its branches are stiffer than any of the others. It thrives in similar situations to the last, and may be propagated and managed in the same way. 
The 'best Bartram specimen is seventy feet high and five and a half feet in circum. ference.

The M. PYRIMIDATA of Bartram is not in the collection now, and is probably a variety of this.

3. M. Conspicua, Salisbury. Leaves obovate, abruptly terminating to a point. Flowers appearing before the leaves.-Chinese magnolia; yulan. Flowering in April.

It is a native of China, where it is said to have been in cultivation over one thousand years; and well it deserves to be. Flowering in the greatest profusion, and at a season when there is nothing else in bloom, and these flowers, too, combining the fragrance of the lily with the beauty of the rose-what can be more desirable? It thrives best in a deep rich loam in a sheltered locality. In England, it seldom grows over ten or twelve feet; here, it will probably rival it in its native localities. The Bartram specimen is small; but there are many fine specimens in the vicinity of the city. It is readily propagated from seed, which it sparingly produces. The best plan is by grafting on the acuminata. 
4. M. Cordata, Michaux. Leaves heartshaped; flowers yellow; fruit ovate, nearly cylindrical.-Heart-leaved magnolia. Native of Georgia and Carolina.

A very hardy round-headed species, much valued for its yellowish flowers, appearing in July. In its native places it grows about fifty feet high. There are very fine specimens in Hamilton's old garden at the Woodlands, and also in Mr. Pierce's arboretum; one specimen four feet in circumference.

5. M. GLAUCA, Linnoeus. Leaves ovate elliptic, white or glaucous beneath; almost evergreen.-Small or swamp magnolia; white bay. Native of the Middle and Southern States.

This tree is naturally a native of swampy places; but I think that, in a good deep loam, it will excel anything indulging in its swamploving habits. It grows luxuriantly in such situations, and very compact and symmetrical; its deep-red seeds contrasting handsomely with the gray green of its foliage. The best Bartram specimen is about twenty feet high.

The M. longifolia of Aiton is but a variety 
of this. M. Thompsonia is a hybrid, between this and M. tripetala.

6. M. GRANDIFLoRA, Linnous. Leaves evergreen, mostly inclining to oval, stiff and leathery, more or less rusty beneath.-Largeflowered magnolia. Native of the Southern States. Flowers in June and July.

One of the most beautiful products of the vegetable kingdom when in its own soil; often reaching ninety feet high. It is only hardy in Philadelphia when grown in dry soils and sheltered places. The one planted by John Bartram is still in existence, but every few winters it is killed to the ground. It loves a loose, deep, and rich soil, rather dry, yet contiguous to moisture. May be propagated as No. 1, by seeds, layers, or grafts.

There are many beautiful varieties, of which the handsomest is perhaps $M$. G. proecox, flowering earlier and larger. There are some fine specimens of this at Bartram, but protected in winter. Mr. Pierce has one in his arboretum which stands out pretty well.

7. M. MACRoPHYLla, Michaux. Leaves large, obovate, slightly cordate at the base. Petals 
six; ovate, incurved. Fruit ovate.-Largeleaved magnolia. Native of Tennessee. Flowers in June and July.

This is a remarkable tree, wandering far away in appearance from the usual forms of arboreal vegetation in temperate climates. It is in every way larger and stronger than M. tripetala, and, like that kind, well calculated to adorn very artificial scenery. It thrives pretty well in the shade of other trees. It seems to do best in a strong loamy soil, if not wet. A fine specimen at Bartram is about thirty feet high and twelve inches in circumference, which is growing in a light loam on a bed of brick earth. It is easily raised from seeds, as No. 1, but is considered very difficult to transplant, unless often removed when young, and "puddled" before being removed to any distance. The finest specimen I have seen is in the grounds of Mr. Pierce.

8. M. soulangeana is a hybrid between $M$. acuminata and $M$. purpurea. It can scarcely rank as a tree, though of a much stronger habit than purpurea. Few things make so pretty a bush as it does. 
9. M. TRIPETAla, Linnour. Leaves lanceolate, inclining often to wedge-shaped. Petals about twelve; exterior ones spreading. Fruit almost cylindrical.-Umbrella-tree. Native of the Middle and Southern States. Flowers in June.

Its large leaves and loose flowing branches give it a peculiar appearance, well meriting its popular name. Near any artificial decorations, in a garden, it is a very appropriate tree. Its leaves fall with the first frost. It thrives well in a cool deep loam, having an abhorrence to soils of a dry, stony nature. The best Bartram specimen is about forty feet high and three feet in circumference.

It is propagated and cultivated as the others.

Morus, Tournefort.-Nat. Ord. Moraceæ. Monœcia, Tetrandria, Linn. Calyx 4-parted. Flowers (in the male) in loose spikes without a corolla. Female flowers in dense spikes. Stigmas two. Calyx becoming a berry, each bearing one seed.

1. M. ALBA, Linnceus. Leaves obliquely 
cordate, shining.-White mulberry. Native of China.

The celebrated morus multicaulis is a variety of this. It usually has a spreading irregular head; the leaves mostly shining, with dark gray bark. It loves a rich soil. It may be easily raised by seeds, layers, eyes, or cuttings. A specimen at Bartram measures thirty-one feet high and thirty-three inches in circumference. There are also varieties with black fruit.

2. M. RUBRA, Desfontaines. Leaves cordate, hairy beneath, scabrous above. Catkins cylindrical. Fruit deep purple.-Red mulberry. Native of the Middle and Southern States.

This is the loftiest of the mulberries, frequently reaching sixty feet. It is very regularly round-headed, and the leaves very large, giving it a bold and strong appearance. The foliage has a deep green hue, but yet lighter than in the M. nigra. The rich-colored fruit, with which it abounds in June and July, adds to its interest. It thrives best in a deep rich loam, in a partially shaded situation. It is raised either from seeds or layers. A spe- 
cimen at Bartram measures fifty feet high and forty-nine inches in circumference.

3. M. NIGRA, Linnceus. Leaves cordate, rugged, smaller than the preceding.-Black or English mulberry. Native of the south of Europe.

This much resembles the other, and is adapted to the same circumstances. The fruit is smaller, and nearly round.

Negundo, Moench.-Nat. Ord. Aceraceæ. Diøcia, Pentandria, Linnoeus. Calyx small; 4-5-toothed. Petals wanting. Anthers 4-5, linear, sessile. Female flowers in racemes; the male ones in bundles.

N. ACEROIDEs, Moench. Leaves of 3-5 leaflets. Leaflets rhombic ovate, coarsely cut and toothed.-Box elder; ash-leaved maple. Native of the Middle and Southern States.

Not so common in gardens as it ought to be. In favorable situations it is a stately tree, growing fifty or sixty feet. When crowded by other trees, the trunk seldom grows straight, and, indeed, never looks so well in any respect as when grown by itself. It very much resembles the ash. It has a 
darker hue than most of that family. The trunk is very apt to throw out knots and small spray, which, in some situations, add to its interest. It will thrive well in any soil, except the driest, in which it is usually short-lived. It can be propagated by seeds, layers, and, with care, by cuttings. It is generally raised from seeds, like the maples. The best Bartram specimen measures sixty feet high and five feet two inches in circumference.

Nyssa, Linnoeus.-Nat. Ord. Alangiaceæ. Polygamia, Diøcia, Linn. Calyx of staminate flowers 5-parted, without a corolla. Stamens 5-10. Pistillate flowers 5-stamened. Fruit a 1-seeded drupe. Nut oval, striated.

1. N. MULTIFLORA, Wangenheim. Leaves oval and obovate, often acuminate. Fertile peduncles about 3-flowered; berry black.-Sour gum; tupelo. Native of the Middle and Southern States.

There is great difficulty in identifying the different species of nyssa. In this neighborhood they vary very much. There are two very different kinds, which, without taking 
upon myself to pronounce them specifically distinct, are yet sufficiently so to be practical. The first variety is round-headed, the branches extending out a long way, and very rigidly, frequently very ruggedly tortuose and twisting; the leaves very much shining, and the berries nearly round. It seldom exceeds fifty feet high. The leaves turn to a yellowishred in the fall. The other grows very erect and tall, with few side branches. It frequently reaches eighty, or even ninety feet, with a circumference of eight or nine. The leaves turn to a deep purple in the fall. The first variety is as frequently found in the very driest as in the wettest places; the latter in situations which can neither be called wet nor dry. They are indispensable trees in ornamental planting. The best specimen (round-headed var.) at Bartram, growing on very gravelly soil, is forty-five feet high and forty-eight inches in circumference. There is a fine specimen of the other kind, but the soil it is in being dry, will not permit it to live there many years more. It may be propagated from seeds sown early in the spring, or as soon as ripe. They seldom grow the 
first season. The soil in which they are sown must not get dry, or they will never vegetate. The young plants should be removed early into nursery-rows, and frequently removed until finally transplanted. This mode will make this tree capable of being easily removed, which is generally supposed to be next to impossible.

Ostrya, Michaux.-Nat. Ord. Corylaceæ. Monœcia, Polyandria, Linn. Male flowers; scales orbicular-ovate; anthers conspicuously bearded at the summit. Female catkins linear, without scales, but having a small membrane inclosing each flower. Nut oblong, included in the enlarged bladder-like membrane. In other respects resembling Carpinus.

O. Virginica, Michaux. Leaves ellipticovate, acuminate, sharply serrate. Cones oblong; buds acute.-Hop-hornbean; ironwood. Native of the Middle States.

A very pretty tree, greatly improved by cultivation. Its head is then spreading, light, graceful, and as elegant as a birch, and becomes near fifty feet high. It will 
thrive pretty well in dry, gravelly soils, provided they be not on a bleak exposure. Indeed, it seems to love company, and, when that is the case, is not over-fastidious about the quality of the soil. It may be propagated as the common hornbean. The best Bartram specimen is fifty-four feet high and three feet six inches in circumference.

Paliurus, Tournefort.-Nat. Ord. Rhamnaceæ. Pentandria, Trigynia, Linn. Calyx 5. Petals 5, upon a glandular disk adnate to the calyx. Fruit dry, girded with a broad membranous wing; 3-celled. Seeds ovate.

P. Aculeatus, Lamarck. Leaves ovate, serrulate, smooth, 3-nerved, with two spines at the base, one straight, the other recurved.Christ's Thorn. Native of the south of Europe.

A small tree, of a very erect habit of growth, and bluish, shining leaves. The large spines are among the peculiarities that give it prominence. It thrives well in dry, gravelly soils, or in the deepest shade. It usually sends up occasional suckers, by 
which it may be propagated; or more extensively by layers, put down before the bursting of the buds in spring; or by seeds, when they can be obtained, which, however, often lie two years in the ground before growing. The best Bartram specimen is thirty feet high and two feet in circumference.

Pavia, Borrhäve.-Nat. Ord. Sapindaceæ. Heptandria, Monogynia, Linn. Calyx tubular. Petals 4, erect, narrow. Stamens straight. Capsules smooth.

P. Flava, De Candolle. Leaflets 5-7, elliptic-oblong, acute at both ends, equally serrate. - Yellow buckeye. Native of the Southern and Western States. Flowers in June.

Grows considerably larger than the British horsechestnut, but has a less spreading and beautiful head. Its habit of growth is quite rugged and stiff, strongly resembling, at a distance, magnolia auriculata. It thrives well in a loose loam, on a dry bottom. The best specimen at Bartram measures 110 feet high and seven feet one inch in circumference.

In the nurseries, these are usually grafted, 
the flowers varying slightly in color from seed. Seed treated as horsechestnuts, make fine plants. The flowers appear later than. the horsechestnut, and the leaves fall earlier.

The $P$. macrostachya is a strong growing and highly ornamental shrub, of which there are several varieties.

Paulownia, Siebold.-Nat. Ord. Scrophulariaceæ. Didynamia, Angiospermia, Linn. Calyx 5-cleft; segments equal, coriaceous, covered with a rusty down. Corolla 2-lipped, imbricated in its æstivation; the two upper lobes external. Fruit ovate, with a sharp point.

P. IMPerialis, Siebold. The only known species is a native of Japan, and thrives admirably in this climate. It is as rapid a grower as the ailanthus, the wood and trunk of the tree also resembling it. The leaves are rather coarse, looking like large melon leaves; but the beauty of the large clusters of sky-blue flowers which appear in June, covers all blemishes. It will thrive in any good loam, and may be readily propagated by cuttings of the roots. 
There are many fine specimens, though but recently introduced, in some of our streets, at Rosedale, and many other places in the vicinity.

PiceA, Link.-Nat. Ord. Pinaceæ. Monœcia, Monadelphia, Linn. Cones erect, cylindrical; scales not thickened at the tip. Leaves more entirely 2-rowed than in abies.

1. P. Balsamea, Linnceus. Leaves solitary, silvery beneath, about a half inch long, somewhat recurved. Cones violet-colored, four inches long, a half inch broad, tapering towards the top. Seed about half the size of the silver fir.-Balsam fir. Native of the Northern and Middle States.

A well known and widely cultivated species. It is readily distinguished from the silver fir by the cones, and easily by practice in the foliage and habit of the tree. It is a very pretty conical tree while young, but becoming very meagre-looking by age, unless in a very deep loam. It does well in most soils, or situations that are not too wet or stiff. The best Bartram specimen is sixty-two feet 
high, and three feet two inches in circumference.

The seed should be sown early in the spring in a bed of sandy loam or peat, rather thinly, and but slightly covered with soil. They will appear in a few weeks. When two years old, they may be removed to nursery rows, planted about eighteen inches apart.

2. P. CEPHALONICA, Loudon. Leaves awlshaped, terminating in a long; sharp prickle; almost sessile, flat, dark-green above, silvery beneath, the base of the leaf of a lighter color than the rest of it.-Cephalonian silver fir.

Growing about sixty feet high in its native country. The largest I have seen near Philadelphia is not over three. It seems most at home in a cool sandy loam. The buds of this species and of $P$. pectinata, are very apt to be destroyed in severe winters, while the plants are young. A little cotton wrapt around the buds of the leading shoots will be a sufficient protection.

3. P. FRAzeri, Pursh. Leaves short, crowded, flat, emarginate, a half inch long, silvery beneath. Cones oblong ovate, bracts obcordate, mucronate, reflexed outwards.- 
Double Balsam fir. Middle and Southern States.

This is allied to the balsamea, but is very distinct. It is considerably smaller in stature, in a wild state seldom exceeding ten feet high, though in a state of cultivation it will often double or treble this. It thrives well in similar situations to No. 1 , and may be treated in the same manner.

4. P. Nobilis, Douglass. Leaves falcate, short, acute, silvery beneath, scarcely one inch long, crowded. Cones erect, six and seven inches long, and three inches thick, ovate cylindrical, scales broad, bracts broadly spathulate, reflexed, covering the scales.Noble fir. North-west coast.

One of the gigantic pines discovered by Douglass. It is considered one of the finest, as it certainly is one of the prettiest-superior, in my opinion, to the Abies Douglasii. Plants in Philadelphia are not over two feet high.

5. P. Pectinata, Loudon. Leaves flat, obtuse, with the points turned up, exhibiting the two silvery lines running lengthwise with the midrib on the under side. Cones in the 
axils of the branches, large, cylindrical, bluntly pointed at both ends, about six inches long, and two broad.-Silver fir. Native of Europe and Asia.

In a deep rich loam, and a sheltered situation, this is one of the most rapid growing and interesting firs. The branches usually grow stiffly horizontal, and, when in fruit, the cones, standing so rigidly erect on the axils, give the species quite an unique character. The best specimen at Bartram is ninetyfive feet high and six feet in circumference. In Mr. Pierce's arboretum there are also some noble specimens, little, if any, inferior to these. In very dry soils it is apt to die out in dry summers, and at any rate be but shortlived. It may be propagated as No. 1, but the seeds should be a little deeper covered.

6. P. PICHTA, Loudon, is generally considered as only a variety of this, with the leaves closer set on the branches, and not so silvery beneath. Specimens about here are not over two feet high.

Pinus, Linnoeus.-Nat. Ord. Pinaceæ. Monœcia, Monadelphia, Linn. Male catkins 
grouped. Pollen contained in 2 cells, formed in the scale that opens lengthwise. Female, ovules 2. Strobile ovately conical in most species. Carpels, or outer scales, thickened at the tip, exceeding the bracteas or thin outer scales in length, and concealing them; persistent. Leaves in groups of two, three, or five, each group arising out of a scaly sheath. (From Loudon.)

1. P. семвra, Linnoeus. Leaves in 5's, sometimes 3 , with three ribs, the ribs serrated, one of them green and shining, the other two. white and opaque. Buds white and without resin. Cones about three inches long and two and a half broad.--Swiss pine. Native of Switzerland and Siberia.

Though a somewhat old and well-known species, it has not become common amongst us.

I have seen no large specimens around Philadelphia. It is one of the slowest growing kinds; yet when large, so very compact and regularly conical, as to be much admired.

The plants in our nurseries are imported chiefly from England.

2. P. EXCELSA, Lambert. Leaves very long, 
in 5's, slender, loose, 3-cornered, 5-7 inches long, angles very finely toothed. Sheaths about half an inch long. Cone about nine inches long and two broad, with a footstalk one inch long.--Lofty or Bhotan pine. Native of Nepaul.

Very nearly allied to the white pine. It can readily be distinguished at sight, by its pale glaucous green hue, and longer, finer, and more crowded leaves.

In stiff cold soils it can scarcely be considered hardy; but in dry sandy soils, and in sheltered situations, not too much exposed to the sun in winter, it is perfectly so.

3. P. halapensis, Aiton. Leaves in 2's. Cones ovate, rounded at the base, nearly the same length as the leaves, with blunt scales. -Aleppo pine. Native of the Levant.

Not a very lofty growing species, but with a very fine green and dense foliage. This stands out in the garden of John Evans, though I searcely think it will prove hardy in most situations here.

4. P. Inops, Aiton. Leaves in pairs. Cones drooping, oblong conical, longer than the leaves. The scales awl-shaped, with promi- 
nent prickles. Cone two and three-quarters to three and a half inches long, one and a half wide, sheaths with three or four rings. -Jersey pine.

A very handsome species, though of somewhat low growth. Its branches extend far horizontally, and form a very symmetrical round head. The leaves are rather fine, and the hue of the foliage not so dark as to be obnoxious. It thrives best in a very light sandy loam, and will do well in any soil that is not stiff or wet. The finest Bartram specimen is sixty-two feet high by three feet in circumference.

It is easily propagated from seeds sown in the spring after ripening. They will grow if two or three years old, but not so readily. Sow thinly, on a bed of sandy loam somewhat cool and shaded, covering in the seed very slightly, just enough to cover them. They ought not to be allowed to get dry at any time. The following spring they may be put out into rows one foot apart, to remain a year or two. After that they should be transplanted to double that distance. They 
transplant easily any time after being grown in this manner.

5. P. Lambertiana, Douglass. Leaves in 5 's, a little rough; sheath very short. Cones cylindrical, twelve to sixteen inches long. Scales loose, spread and rounded above.Gigantic pine. Native of the North-west coast. This is said often to grow two hundred feet high, and to be as hardy as the white pine, to which it is allied. In the garden of John Evans, it thrives admirably in a cool sandy loam. When the nuts can be obtained, they may be sown as soon as received, and raised in the manner of the araucaria imbricata.

6. P. MITIS, Michaux. Leaves two, sometimes three in a sheath, long, slender, hollowed on the upper surface. Cones small, ovate, conical. Scales with their outer surface slightly prominent, and terminating in a very small slender point, bending outwards.Yellow pine. Northern and Middle States. This has a very elegant appearance. The bluish tinge of the long slender foliage is almost peculiar to it. The Bartram specimen, on a dry gravelly soil, with a rocky 
bottom, is ninety feet high, and four feet eight inches in circumference.

Propagated as No. 4.

7. P. Palustris, Aiton. Leaves in 3's, about twelve inches long, growing in tufts at the ends of the branches. Cones nearly cylindrical, covered with stiff bristles.Southern swamp pine. Native of the Southern States.

A rather odd looking pine, growing about fifty feet high, and thriving in wet swampy places. There is a small specimen in the garden of John Evans.

8. P. Pinaster, Aiton. Leaves two in a sheath, four to six inches long, somewhat rough at the edge. Cones oblong, three to five inches long, narrowed at the base, scales bristly.-Pinaster. South of Europe.

A coarse, free growing species, very hardy, round-headed, will thrive almost anywhere. These are its best recommendations. It is not so handsome as many others.

Propagated as No. 4.

$P$. Maritima is a variety of this.

9. P. PINEA, Linnoeus. Leaves in 2's, earlier ones ciliate. Cones ovate, obtuse, without $15^{*}$ 
prickles, longer than the leaves. Nuts large. - Italian stone pine.

One of the most useful as well as handsome of the tribe. No soil is too loose or too barren for it to thrive in, nor any situation too bleak or exposed. The seeds (which are four years coming to perfection with the cone) may be sown singly, as recommended for the araucaria or No. 5 .

10. P. ponderosa, Douglass. Leaves in 3 's, nine to eleven inches long, flexible, tortuous. Sheaths short. Cones ovate, reflexed, with the ends of the scales flattened, with a raised process in the middle.-Heavy wooded pine. Native of the North-west coast.

Said to grow from fifty to eighty feet high in its native country. Plants in this vicinity are not over three feet high, but it promises to be a rapid and strong grower. Our plants are imported from Europe; but where seed can be obtained, they may be treated as No. 5 .

11. P. Pumilio, Hoenke. Branches generally bent down. Leaves short, stiff, a little twisted, thickly distributed over the branches, with long, lacerated, woolly, white sheaths. Cones, when young, erect; older growing 
outwards, one and a half to two inches long, one inch broad. Scales and seeds small.Dwarf pine. Native of the mountains of Europe.

It is said to grow not more than twenty feet high in its native country. It will probably exceed that here. It is a very distinct looking kind. It will thrive in any light loam, provided it is not in a situation exposed to our hot sun. It is easily raised from seed, like No. 4. The plants in our nurseries are generally imported in pots, and if kept too long in them seldom do well. In all such cases, the roots should be uncoiled and spread out in planting.

12. P. RIGIDA, Miller. Leaves in 3's, three and a half to four inches long. Cones ovate oblong, two to three inches long, about one and a half broad, their scales terminated by a rough thorny point.-Pitch pine. Native of the United States.

Growing by itself, this is remarkable for the irregularity and number of its branches. They are usually spreading, covered by foliage of the darkest green. It will grow in any soil, from the dryest to those frequently 
inundated; a moist sandy loam seems to suit it best. A specimen at Bartram growing on a rock, with very little soil, is fifty-four feet high and four feet six inches in circumference. It may be propagated like No. 4.

13. P. Strobus, Linnous. Leaves in 5's, slender, without sheaths, three to four inches long, straight, soft, and 3-cornered. Cone long, cylindrical, pendulous, with the scales not thickened at the apex.-White pine. Native of the United States.

A well-known species of the highest utility in landscape gardening. When not crowded by others it is highly ornamental, producing branches regularly from the ground, and forming a symmetrical figure. When young, it is not so handsome to most tastes; but that gives it an advantage that always pleases, of improving in appearance as it grows. The bluish tinge it possesses removes the objections made to many of the tribe on account of their funereal hues. The finest Bartram specimen is one hundred and eighteen feet high and seven feet three inches in circum. ference. There are also some splendid specimens in the large avenue in Pierce's arbore- 
tum, which, though only planted in the year 1800, now average seven and a half feet in circumference, and are between ninety and one hundred feet high, to all appearance. It prefers a rich, yet loose and dry loam, on a gravelly or rocky subsoil. It will do pretty well in heavy loam, but in cold, clayey, wet soils the white pine is decidedly not at home.

It may be propagated as No. 4 .

14. P. sylvestris, Linnous. Leaves rigid, in pairs, one and a half to three inches long, somewhat waved and twisted, slightly concave on the upper, and convex on the lower surface, finely serrated on the edges. Cones from two to three inches long, and from one to one and a quarter broad.-Scotch pine. Native of the mountains of Europe.

By no means so handsome as many others, but in this country we have no evergreens to spare. Still, it is highly appropriate to many situations, where few similar trees would grow. Its dark hue, and, when mature, stiff compact habit, render it well fitted for cold looking, rugged scenery. If not crowded by other trees, it does not become so naked on the trunk, or so flat-headed as it is usually seen 
or supposed to be, and is then more symmetrical and more beautiful. A specimen at Bartram slightly varying from the true form, is thirty-five feet high, and three feet in circumference. It delights in a dry deep loam, and in somewhat elevated situations. It will do pretty well in any gravelly or dry peaty soils, but little good in any that are wet.

May also be propagated as No. 4 .

15. P. TADA, Linnceus. Leaves in threes. Cones oblong, conical, shorter than the leaves, growing in clusters; scales with rough prickles.-Frankincense pine. Native of the United States and Canada.

Somewhat in the way of the last, but readily distinguished by the number of its leaves in the sheaths, as well as by its other characters. It reaches a good height, and thrives pretty well in most soils that are not wet. Plants are scarce in our district, but one exists in the collection of John Evans.

Platanus, Linnceus.-Nat. Ord. Platanaceæ. Monœcia, Polyandria, Linn. Male flowers in globular heads. Corolla very 
small. Anthers growing round the filament. Female flowers with a many-petalled corolla. Style with a recurved stigma. Seeds roundish-clavate, mucronate, with a persistent style, invested with pappus-like hairs at the base.

1. P. occidentalis, Linnceus. Leaves roundish-pentangular, slightly palmate, downy beneath.-American buttonwood.

This tree was formerly in much demand for its shade; latterly (suffering from late frosts, probably) it has fallen into disrepute from its unhealthiness. I believe it carries the disease with it even to other countries. In landscape gardening it can only be employed effectively as a single specimen. It does not harmonize well with other trees. By itself, its magnificent proportions, its broad-spreading habit and large ample foliage, challenge admiration. It will do well in any situation, but prefers one inclining to moisture. A specimen at Bartram is ninetyfive feet high and six feet in circumference. May be propagated from seed sown as soon as ripe* in a moist yet light soil, covering

* Emerson recommends to soak the seed twenty-four hours before sowing in the spring. 
them very slightly with the earth. They may stay two years in the seed-bed before transplanting, after which they will make rapid growth, and may be safely removed any time after. With care, cuttings will grow pretty well. The young but wellripened wood is taken off early in the winter, laid in "by the heels" in any sheltered spot, and put out in rows in a warm border very early in spring. Layers succeed well put down in July, or as soon as the wood seems perfectly ripe.

2. P. orientalis, Linnceus. Nerves of the leaves smoothish beneath. Lobes more palmate than in No.1.-English buttonwood.

Seldom makes so large a tree as the other, but is free from its disease. It is a week later in putting forth, which may be one reason for its healthiness. It will grow well in dryer situations than the last. A specimen at Bartram measures eighty feet high and four feet in circumference.

Populus, Linnceus.-Nat. Ord. Salicaceæ. Diœcia, Octandria, Linn. Calyx of the male, the flat scale of the catkin torn at the edge. 
Corolla turbinate, oblique, entire. Female, stigma 4-cleft. Capsule 2-celled, many-seeded, bristly.

1. P. ALBA, Linnceus. Leaves lobed, toothed, white beneath; lobes acute, flat. Stig. mas four.-Abele; white poplar. Native of Britain.

A tree formerly very popular, on account of its rapid growth and lively foliage, but which planters now often wish back again to its native country, because of its great propensity to throw up suckers; still, where this is not objectionable, as in towns as street-trees, it will often be desirable. The whole of the poplar tribe has strong claims to be distinguished in a catalogue of streettrees; few things bearing the smoke and dirt better. This species grows lofty and somewhat conical, with a gray bark; and, with its two-colored leaves, bears a good character for beauty.

Pieces of the two-year old wood, cut into three to four inch pieces, and planted nearly their whole length in a rather moist and shaded spot, very early in spring, grow like willows. 
2. P. Angulata, Aiton. Shoots angular. Leaves heart-shaped, tapering at the point, very large, and with fine serratures.--Cottonwood poplar. Native of the Western States.

One of the most ornamental of poplars. It is of very rapid growth, and, when full grown, is round-headed and spreading. The leaves are very large and glossy, and, the petioles being very flat, possess an aspen character. The light and shade from the leaves, as they are moved by every little breeze, gives the tree a playfully pleasing appearance. It does not do well in very dry situations, but has no decided objections to others. It may be propagated as No. 1 .

The finest specimen I have seen, probably eight feet in circumference, stands by the road-side near old Humphrey Marshall's garden.

3. P. Balsamifera, Linnous. Shoots round. Buds very gummy. Leaves ovateacuminate, serrate, whitish beneath; petioles round.-Balsam poplar.

Very short-lived in dry soils. It prefers those that are deep, moist, and rich. It is 
OF ORNAMENTAL TREES.

somewhat inclined to throw up suckers in dry soils. May be propagated as No. 1.

The best Bartram specimen is seventy feet high and four and a half feet in circumference.

4. P.canadensis,Michaux. Young branches angled. Leaves cordately ovate, tapering to a point, finely and rather unequally toothed; petioles compressed; buds gummy.-Canadian poplar. Native of the Northern States.

It frequently grows to eighty or ninety feet high, and is well worthy of a place in any collection. In soils similar to the last.

5. P. Candicans, Aiton. Shoots round. Buds very gummy. Leaves heart-shaped at the base, ovate-acuminate; petiole flattened in the upper part, frequently hairy.-Ontario poplar; balsam poplar of the Northern States.

It is in every way a larger and a finer tree than the true balsam, and is readily distinguished by the leaves.

6. P. CANescens, Smith. Leaves roundish, very slightly lobed, toothed. Stigmas eight. -Gray poplar. Native of England.

By many considered a variety of the abele. 
A fine young specimen at Bartram is about fifty feet high and eighteen inches in diameter.

7. P. Dilitata, Aiton. Leaves.smooth on both sides, acuminate, serrate, wider than their length.-Lombardy poplar. A wellknown and formerly very popular tree, on account of its easy and rapid growth, and singular fastigiate appearance. Though in little demand at present, there are many situations in which it is singularly effectiveas where horizontal lines prevail, or highly artificial scenery. In the fall, the leaves turn to a rich golden yellow hue, equalled by few other trees. They also remain on to a late period of the season.

Propagated as No. 1.

8. P. GRÆCA, Aiton. Leaves cordate, ovate, acuminate, serrate, serratures somewhat clawed, glandular at the base, petioles compressed. -Athenian poplar. Native of the islands in the South of Europe.

An irregular, somewhat spreading-headed tree, growing often to fifty feet high. In Europe, this is sometimes mistaken for $P$. heterophylla, Linnoeus, which may have given 
rise to the idea that it is also a native of the United States.

9. P. grandidentata, Michaux. Leaves downy when young, afterwards smooth on both surfaces. Sinuately toothed, with large unequal teeth.-Large American aspen. Native of the Northern States.

A very fine tree when in a rather moist situation, and unsurrounded by other trees. It is not too troublesome by suckering, as some of the others are. The best specimen at Bartram is sixty-two feet high, and three feet two inches in circumference.

10. P. TRemuloides, Michaux. Leaves roundish, heart-shaped, shortly pointed, slightly toothed. Bracts deeply 3-4-lobed, lobes linear.-American aspen.

This, in moist, somewhat shaded situations and not too much crowded, is an ornamental round-headed tree, and though not so pretty as the European, has its leaves shaken, like it, by every playful breeze.

Prunus, Tournefort.-Nat. Ord. Drupaceæ. Icosandria, Monogynia, Linn. Nut ovate or $16 *$ 
oblong, flattened, sharp at both ends, furrowed at the edges, smooth in the other parts.

1. P. americana, Marshall. Branches subspinose. Leaves oval and obovate, acuminate, sharply and often doubly serrate. Umbels nearly sessile, 2-5-flowered.-American red plum.

A small round-headed tree, usually growing but fifteen feet high. Near the door of Marshall's old house is a specimen, probably of his own planting. The Bartram specimen is much finer, being about thirty feet high and two feet six inches in circumference.

It is propagated by seed; or more speedily by layers. A stool should be kept for this purpose; that is, a tree should be cut down to nearly the ground, which will throw out an abundance of shoots. These, which will be fit for layering about June, should be each gently twisted, and earth placed around the whole until the twisted part of the shoots are covered. The spring following, these being well rooted, may be taken off as plants.

2. P. MARITIMa, Wangenheim. Leaves lanceolate, ovate, serrate. Flowers in pairs. Fruit small, round, sweet, dark blue.-Sea- 
side plum. Native of the Eastern and Southern States.

Naturally but a shrub, but becoming a very ornamental small tree when budded on the P.Americana. It is rather scarce in cultivation. There is a specimen in the garden of John Evans, at Radnor.

Ptelea, Linnoeus.-Nat. Ord. Xanthoxylaceæ. Monœcia, Tetra-Pentandria, Linn. Calyx 4-5-parted. Fruit compressed, of 23-cells. Cells 1-seeded, each cell expanded into a rounded netted wing.

1. P. trifoliata, Linnous. Leaves in 3's. -Native of most of the Middle States.

A small tree, possessing no particular beauty to recommend it. When in fruit it is curious. It has the advantage of thriving in the deepest shade, especially if in a rather moist soil.

It can be readily propagated by cuttings, layers, or seeds.

The Bartram specimens grow about ten feet high. 
Pyrus, Linnoeus.-Nat. Ord. Pomaceæ. Icosandria, Pentagynia, Linn. Calyx 5-cleft. Petals 5. Fruit a 5-celled, many seeded apple.

1. P. ARIA, Smith. Leaves ovate, cut and serrated, white and downy beneath. Flowers corymbose. Fruit globose.-White beam. Native of Britain. Flowering in June.

At a distance, has much the appearance of a mulberry tree. The downy under surface makes a fine contrast to the deep green of the upper. It thrives best in a limestone soil, where it frequently reaches fifty feet high, but it will do well in any firm loam in an open situation. It varies much in foliage, sometimes being quite pinnatifid. The $P$. pinnatifida, Ehr., and $P$. hybrida (Sorbus), Linn., are now considered varieties of this. It may be propagated by seeds sown as soon as they are ripe in a box, or protected situation; or by budding on the mountain ash. The latter mode is the commonest, but such trees are not near so desirable as those on their own roots.

2. P. AUCUPARIA, Goertner. Leaves pinnated, glabrous, leaflets serrated. Flowers 
corymbose. Fruit globose, small, red.Mountain ash; Rowan. Native of the mountains of Europe. Flowers in May.

This beautiful tree grows about thirty feet high, and has the round-headed spreading habit of the apple, with the foliage of an ash. Its clusters of white flowers, followed by red berries, are its chief attraction. It thrives best in a loose dry soil, in a situation somewhat shaded. The P. Americana, Dec., is considered to be a variety of this. It is propagated as the last. Sometimes they will not appear the first year, unless the seed has been thrown in a heap to ferment previously.

There is a specimen at Bartram forty-five feet high and three feet in circumference.

3. P. Baccata, Linnoeus. Leaves equally serrulated. Peduncles clustered. Fruit small and berry-like. Calyx deciduous.-Cherry apple. Native of Siberia.

A small tree, seldom exceeding twenty feet high, but very popular on account of the profusion of its red cherry-like fruit.

3. P. coronaria, Linnceus. Leaves ovate, slightly heart-shaped at the base, sharply serrate or nearly lobed, smoothish. Pedun- 
cles corymbose, smooth.-Sweet-scented crab. Native of the Middle and Western States.

A small bushy-headed tree, growing about fifteen feet high, and valued chiefly for its pale-red, sweet-scented flowers, which appear in May. Scarce in cultivation, but growing in the garden of John Evans.

4. P. Domestica, Smith. Leaves pinnate, villose underneath. Leaflets serrate. Flowers panicled. Fruit obovate.-True service-tree; Sorbus. Native of Britain.

Resembling the Rowan, but is in every way a more vigorous grower. The branches are stouter, the leaves larger and coarser, and the fruit like a small crab-apple, full an inch in length.

5. P. NIvalis, Linnceus. Leaves quite entire. Flowers in corymbs. Fruit globular.Snowy-leaved pyrus. Native of mountains of Austria.

A shrub, ranking only as a tree when grafted on the larger kinds. Growing in the garden of John Evans.

6. P. PRUNifolia, Willdenow. Leaves ovate acuminate. Flower-stalks pubescent. 
Styles woolly at the base.-Plum-leaved Siberian crab.

Cultivated chiefly for its early, pear blossom-like flowers, yellowish-red fruit, and its extreme hardiness. The Bartram specimen is about fifteen feet high.

7. P. spectabilis, Aiton. Leaves oval-oblong, serrate, even. Claws of the corolla longer than the calyx. Styles woolly at the base.-Double flowering apple. Native of China.

The most ornamental flowering one of the tribe. It reaches about twenty-five or thirty feet high, and has more the appearance of the common apple than any other species. It does best in a deep, rich, loamy soil, and is propagated by grafting or budding on the ordinary kind. Specimens in our vicinity are not over fifteen feet high.

8. P. ToRminalis, Smith. Leaves ovate or cordate, lobed, and serrate; lower lobes spreading. Peduncles corymbose. - Wild service-tree. England.

A handsome species, growing about fifty feet high. It prefers a limestone soil, but will do pretty well in a strong rich loam. It 
is rather scarce. There is a specimen in the garden of John Evans.

Quercus, Linnoeus.-Nat. Ord. Corylaceæ. Monœcia, Polyandria, Linn. Male catkins with flowers having a 5-cleft calyx, with 410 stamens, and no corolla. Female flowers; calyx an involucre composed of numerous scales united into a cup. Fruit, an acorn.

1. Q. ALBA, Linnceus. Leaves obovate-oblong, nearly equally pinnatifid sinuate, shining green above, a little whitish beneath. Cup hemispherical. Nut ovate or oblong. White-oak. Native of United States.

All the oaks are amongst the most useful trees in landscape gardening. They possess a great variety of forms and modes of growth; different colors, shades, and hues; and are adapted, some one or other of them, to every difference of soil, situation, and aspect. They are usually considered of slow growth, but when under favorable circumstances, soon attain a large size. A magnificent avenue of them, on the fine estate owned by Alexander Brown, Esq., on the 
Delaware, planted since the Revolution,* show what they can do in a short time; and a small and thriving one at Bartram, fourteen years planted, contain some above forty feet high. This species is one of the handsomest, whether considered with regard to its noble size, its beautiful form, its peculiar elegant leaves, both in outline and hue, or its frequently grotesquely-twisted branches. Singly; in the landscape, I know of no other tree that can be compared with it. I would desire to see no better emulation in gardening than in a desire to possess the best whiteoak. The grounds of Bartram and Springbrook are equally enriched in this respect; the former having one eighty-five feet high by thirteen feet in circumference, and Mr.

* In reference to this avenue, Mr. Cope has kindly obtained for me the following information from Mr. Samuel Breck: "This estate was purchased by my father about 1796 . The only access to it was by a lane on the east side, that goes down to the Delaware. This being a roundabout way, he purchased an outlet on the turnpike ; and, having considerable taste for rural adornment, planted and arranged the avenue, aided and assisted by Frederick Pursh, then in his employ (who was also gardener to W. Hamilton, at the Woodlands), in 1797." 
Cope's measuring seventy-two feet high by twelve feet in circumference. It varies very much in the lobing of the leaves. In dense woods, the leaves are merely sinuated; in open, exposed situations, they are very deeply lobed, nearly pinnatifid. Very commonly, though not always, the bark is scaly, like the shellbark-hickory. In the fall of the year, the leaves turn to a deep reddish-brown; in young trees often staying on till spring. It thrives best in dry loams contiguous to streams or moisture. All the species are easily raised from seed sown as soon as ripe, and the best trees are raised from the youngest plants that find an early permanent situation.

2. Q. AQUATICA, Walter. Leaves somewhat wedge-shaped, narrowed at the base, lobed, smooth.-Water-oak.

Somewhat allied to the Black-Jack, but often growing fifty feet high. It varies very much in its foliage. The best soil for it is a sandy loam contiguous to moisture. It is rather scarce in cultivation. There is a specimen in the garden of John Evans.

3. Q. BALIota, Desfontaines. Leaves ever- 
green, elliptic, toothed or entire, downy beneath. Acorn very long.-Barbary-oak.

This is a fine tree; sixty feet high in its native country. It will probably not stand out here in situations exposed much to the sun in winter, or little sheltered; but I believe it does pretty well in the garden of my friend Evans.

4. Q. BICOLOR, Willdenow. Leaves oblongovate, acute, softly downy beneath, coarsely and unequally dentate, the teeth rather acute. Fruit on long peduncles; cup hemispherical; nut ovoid-oblong.-Swamp white-oak.

Seldom exceeding fifty feet. Has a very pretty, regularly spreading, large head, frequently larger, in proportion to the size of the trunk, than any other species. The bark is slightly scaly. It thrives best in a low situation and moist soil. The best Bartram specimen is sixty feet high, with a head about forty feet in diameter.

5. Q. Castanea, Willdenow. Leaves oblong, lanceolate, acuminate, pubescent, and of a pale gray beneath, nearly equally toothed, the teeth rather sharp. Cup hemispherical. Nut roundish.-Chestnut-oak. 
The resemblance of this to a chestnut-tree is striking, not only in its foliage, but also in the color and appearance of the bark, and in its general habit and appearance. It thrives best in rich soil, and in elevated situations. It does not do well in tenacious clays. In dry, gravelly soils, I have seen it do pretty well. The best Bartram specimen, a young one, is thirty-feet high.

6. Q. CERRIS, Linnoeus. Leaves sinuate, pinnatifid, pubescent beneath. Cup covered with branching bristles.-Turkey oak. Native of the south of Europe.

In England, this is a very pretty roundheaded tree. Here it takes a more pyramidal form, with a tendency to extend its branches far horizontally. The leaves have a peculiar, curled, and cut appearance, giving the tree quite a "distinction with a difference" amongst its fellow oaks. There are many fine varieties, but few of them introduced here. The leaves of our species stay on green till near Christmas, and remain on till the bursting of the buds the following spring. It thrives best in a loose, shady 
loam, that does not get hot or dry in summer.

It is propagated by seeds, or, most commonly, by grafting on the other species.

7. Q. Coccinea, Wangenheim. Leaves on long petioles, oblong, deeply sinuate lobed, smooth; the lobes divaricate, toothed. Cup nearly top-shaped, conspicuously scaly. Nut, roundish-ovate.-Scarlet-oak.

I consider few oaks superior to this in beauty. In the fall of the year it bears off the palm. Its leaves then become red, frequently reaching a fine scarlet. It averages fifty feet high, though some are occasionally found nearly doubling that height. It is rather an irregular grower, when old often inclining to become flat-headed. Its long leafstalks permit an easy motion of the leaves with every summer breeze, and gives motion as an additional attraction to the beauties of its autumnal foliage. It thrives best in a deep rich loam, inclining to moisture.

8. Q. FALCATA, Walter. Leaves downy beneath, sinuated, with three or four somewhat sickle-shaped, bristle-pointed lobes, the terminal one elongated and jagged. Fruit small. 
Calyx hemispherical. Acorn of a bright orange color inside.-Spanish red-oak. Native of the Middle and Southern States.

A tree with very variably shaped leaves, and yet with such a constant rusty, downy peculiarity as renders it at all times easily recognized. It grows to a large size, but seldom forms a regular or picturesque head. Its foliage is the chief point of interest that renders it attractive. It delights in a rich and rather dry loam. The Bartram specimen is a young tree of forty feet high by three and a half in circumference.

9. Q. Heterophylla, Pursh. Leaves on rather long petioles, ovate-lanceolate, oblong, entire, frequently with large irregular teeth. -Bartram oak.

Partaking of the characters of Q. Phellos, and $Q$. imbricaria, and supposed by many to be a hybrid between them. I cannot subscribe to this opinion; firstly, because I cannot learn that flowering plants of Q. imbricaria ever existed in Bartram, and secondly, because seedlings of the phellos show no tendency to vary, and seedlings of $Q$. heterophylla have more or less the characters of the origi- 
nal. The tree from which Pursh drew up his description, was privately destroyed by some of Mr. Hamilton's gardeners (as I have been informed by Col. Carr), because it interfered with a view of the Schuylkill from the Woodlands. A seedling from this tree at Bartram is seventy feet high and six feet in circumference. The leaves of this are considerably narrower than those of another tree at Marshall's garden; making it appear, without examination, like a willow oak. Marshall's specimen, on the other hand, has its leaves much resembling those of a $Q$. imbricaria, Michaux, which is growing beside it with a trunk seven feet three inches in circumference, and probably ninety feet high. The leaves of this latter are broader and shorter than either the Bartram or the willow oak.

10. Q. LYRATA, Walter. Leaves subsessile, glabrous, lyrately sinuated, much contracted in the middle, attenuated at the base, and dilated at the summit. Cup globular, rough, and almost covering the acorn.-Lyrate oak. Water white-oak. Native of the Southern States.

This, though perfectly hardy at Bartram, 
never ripens its seeds there. This may be owing to the fact of its growing there in dry gravelly soil, while in its native places it is found in swamps. Nevertheless, our specimen has attained a fair size, being sixty-two feet high and six feet two inches in circumference. It has something the appearance of a white-oak when seen at a distance, and in the Bartram tree, indicates a head of a very spreading character.

11. Q. MACRocarpa, Michaux. Leaves lyrate, downy beneath, deeply and sinuately lobed, the lobes obtuse and spreading. Cup deep, scaly, and fringed with bristles. Acarns large, thick, and ovate.-Burr oak. Overcup white-oak. Native of the Western States.

A powerful rival to the white-oak, having the advantage besides of very handsome acorns. The Bartram specimens, on dry gravelly soils, do not indicate very lofty trees, but have widely spreading heads. The finest is sixty-three feet high and six feet in circumference.

12. Q. NIGRA, Linnoeus. Leaves broadly wedge-shaped, slightly 3-5-lobed at the end, covered with rusty dots beneath. Cup very 
scaly. Acorn roundish-ovoid, small._-BlackJack.

A very useful small tree, thriving in the most thin and barren soils, and giving, by its large shining leaves, a gay appearance. In deep rich loams it grows beautifully, and will reach fifty feet high. The Bartram specimen in dry gravel is about thirty feet high.

13. Q. obtusiloba, Michaux. Leaves obovate-oblong, wedge-shaped at the base, irregularly sinuate, lobed, the upper lobe dilated, retuse. Cup hemispherical, scaly, nut elliptic-ovoid.-Post-oak. Barren white-oak.

This is a singular looking tree, having but few branches, and these very long, forming a very meagre looking round head. The branchlets are so small as to appear stunted, while the leaves are rather above the average size. It thrives best in a dry situation. The best Bartram specimen is thirty feet high by forty two inches in circumference.

14. Q. OLIV жFormis, Michaux. Leaves oblong, glabrous, glaucous on the under side, deeply and unequally sinuate pinnatifid. Fruit elliptic ovate, cup hollowed out, bristly 
on the upper side.-Olive shape fruited oak. Native of the Middle States.

Growing to the height of about fifty feet, and thriving in deep loam, in an elevated and dry situation. Scarce in cultivation, but is in the collection of John Evans.

15. Q. Palustris, Duroi. Leaves oblong, deeply cut or sinuate lobed, smooth, green, and shining; acorn small and subglobose, often striped with blackish-brown before quite ripe.-Pin oak.

A very pretty conical-headed tree, with leaves of a light yet lively green, each very deeply cut, and with the lower branches often pendulous, sweeping the ground, and forming a pleasant shade. Though generally considered a swamp tree, it will flourish in the driest situations; a desirable quality in an universal favorite. The largest Bartram specimen is eighty feet high and eight feet in circumference.

16. Q. PHELLOS, Linnoeus. Leaves lanceolate, quite entire. Fruit small, acorn of a deep orange color inside.-Willow oak. Native of the Middle and Southern States.

A peculiar looking oak with dark green 
willow-like leaves, and an ovately conical head. Its foliage remains green till a late period of the season. It thrives best in low moist land of a rich quality, but will do well in dry and elevated situations. The best Bartram specimen is eighty-three feet high and seven feet two inches in circumference.

17. Q. PRINUS, Linnceus. Leaves obovate and elliptic-oblong, pubescent beneath, with wide, blunt, equal teeth. Fruit pedunculate. Cup hemispherical. Nut ovoid.-Chestnut white-oak.

Usually grows to a great height, often over one hundred feet. It somewhat resembles the castanea. The latter is often mistaken for a chestnut; the former would never be taken for anything but an oak. In the specimens that have come before me, the head is always bold and irregular, but would probably be more symmetrical when grown isolated from other trees. It will grow to a fine size in dry, rocky, or gravelly soil, but attains its finest proportions in low and rich situations. The best Bartram specimen, on dry gravel, is eighty-two feet high and five feet six inches in circumference. 
18. Q. RoBUR, Linnous. Leaves oblong, somewhat wedge-shaped, smooth and irregularly sinuate, lobes rounded, acorns cylindrical.-British stalked oak.

A very valuable kind in ornamental gardening from the fact of its foliage remaining on green till the frost fairly "drags" it off; while its glossy green summer dress is "highly becoming." It does not often exceed sixty feet high in its native country, but in America, which is pre-eminently adapted to deciduous trees, it will do much better. The Bartram specimen, growing on thin soil on a rock, is eighty feet high and seven feet in circumference. In general appearance it is allied to our white-oak, but the bark is never scaly, nor are the leaves ever so deeply lobed. It will do well in any situation not too wet. $Q$. $R$. purpurea, with fine purple foliage, is a very ornamental variety, of which small specimens are in our vicinity.

It is propagated by grafting on the com. mon kind.

19. Q. RUBRA, Linnous. Leaves obtusely sinuated. Cup very flat, with shallow edges. 
Nut large, oblong, ovoid.-Red oak; Champlain oak.

The trunk and bark of this tree much resemble a chestnut; the branches have a very coarse and rigid appearance, sufficient to distinguish the tree readily even in winter. It makes a pretty object as a single specimen. It thrives well in very poor soils, but will not do well in low or wet situations. A specimen at Bartram is about sixty feet high and four and a half feet in circumference. There is a noble specimen a few feet off the boundaries of the Bartram estate; but there is no certainty when it may go to form "post and rails," as I have been informed a solitary specimen of Q. ambigua, Michaux, in the vicinity once did.

20. Q. SESSILIFLORA, Salisbury. Leaves. on long stalks, oblong-ovate, deeply sinuated, their sinuses acute, lobes obtuse. Fruit clustered on very short stalks or sessile.-Sessile-fruited British oak.

This is very like the $Q$. Robur, and by many thought to be but a variety of it. It is considered the most ornamental of the two. I believe it is not so common as the other, 
but may be found in the collection of John Evans.

21. Q. sUBER, Linnceus.-Leaves evergreen, ovate oblong, tomentose beneath, wavy.Cork-tree. Native of the south of France, Barbary, \&c.

Also growing in the garden of John Evans. It is not generally considered hardy, but will doubtless prove so in situations shaded from our winter's sun.

22. Q. TINCTORIA, Bartram. Leaves obovate-oblong, sinuate-lobed, pubescent beneath. Cup turbinate. Nut ovoid.-Black oak; quercitron.

Its large, luxuriant, dark glossy foliage, is its chief value in ornamental gardening. The tree itself has a very unpicturesquelooking head; and, in our neighborhood, is noted for a general decay, even young trees frequently losing large branches. It does best in a rich loam on a clay bottom.

Rhamnus, Linnoeus.-Nat. Ord. Rhamnacer. Pentandria, Monogynia, Linn. Calyx swollen out with a 4-5-cleft border. Petals $4-5$; sometimes wanting. Styles $2-4$, dis- 
tinct, sometimes combined. Fruit, a 2-4seeded berry.

1. R. CARoliniensis, Walter. Leaves ovaloblong, obscurely serrate, nearly smooth. Umbels axillary, on peduncles much shorter than the leafstalks. Flowers 4-5-stamened. Petals embracing the very small stamens. Stigmas three. Fruit globose. - Carolina buckthorn.

I give a full description of this species, as it is too little known. It is a round-headed tree, of a very pretty habit; while the red berries which cover it in the fall, and which subsequently change to a deep black, render it highly interesting, not merely for their own simple beauty, but also for the variety of birds they attract. It is impatient of moisture, and also of extreme drought, thriving: best in a deep, cool loam. A specimen at Bartram is about twenty feet high and twelve inches in circumference.

It is readily propagated by seeds sown as soon as ripe. They sometimes remain in the ground two years before they grow, though very seldom. It may also be raised by cuttings or layers, but as these take twelve 
months at least to root well, I prefer the former mode.

2. R. Catharticus, Linnceus. Leaves ovate, sharply serrate. Flowers 4-cleft, diœcious. Spines terminal. - Buckthorn. Native of England.

Most generally seen as a shrub, but by a little pruning when young, makes a handsome round-headed tree, often attaining, under favorable circumstances, a height of twenty-five feet, and a circumference of two feet. It delights in a rich loam, inclining to moisture. It will grow well in dry soils, but is there short-lived. Propagated as No.1.

3. R. FRANGULA, Linnceus. Without spines. Flowers perfect. Leaves obovate, entire.Alder buckthorn.

This is usually but a strong shrub, but, like the last, becomes a small tree, having the appearance of No. 1 by cultivation and management. A specimen is in the garden of John Evans, at Radnor.

RHus, Linnoeus.-Nat. Ord. Anacardiaceæ. Pentandria, Trigynia, Linn. Calyx 5-parted. Petals five, ovate-lanceolate, spreading. Fruit, 
a one-seeded berry, nearly dry, with a bony nut.

1. R. cotinus, Linnous. Leaves simple, ovate.-Venetian sumach; mist-tree. Native of the south of Europe.*

In Europe but a small shrub, it rises here to the dignity of a small tree by the aid of a little pruning when young. With its darkgreen roundish leaves, and its formal round head, it is peculiarly pleasing in many situations; and, when covered with its flowers, looks literally like a "mist." It is readily propagated by layers laid down just before the bursting of the leaf. The following spring they may be treated as separate plants.

2. R. TYPHINA, Linnous. Leaves pinnate, leaflets in many pairs, lanceolate, acuminate, tomentose beneath. Panicles terminal. Stag's-horn; sumach.

A small tree, fifteen to twenty feet high, and the most ornamental tree I know of its size. Its dark-green leaves rival those of the ailanthus in the "orientality" of their

- De Candolle makes a separate genus of this under the name of Cotinus. 
appearance; and when in the summer months the tree is covered with its large, erect panicles of red berries, the effect is beautiful in the highest degree. Unfortunately, it is one of the most inveterate suckerers in the vegetable kingdom. Its admirers must be careful to select a position for it where this propensity will not prove objectionable. It thrives best in a light, dry, and rich soil, making no progress in a wet one.

3. R. venenata, De Candolle. Leaves pinnate; leaflets obovate-oblong, sharply acuminate, the margin very entire, and slightly revolute. Panicles loose, on long peduncles.-Poison-ash; poison-sumach.

This tree possesses little beauty, and, from its poisonous properties, none but an enthusiastic lover of trees in all their forms will be induced to cultivate it. It thrives best in a moist situation. The Bartram specimen is about fifteen feet high.

Robinia, Linnceus.-Nat. Ord. Fabaceæ. Diadelphia, Decandria, Linn. Calyx 4-cleft; the upper division slightly notched. Legume compressed, many-seeded, gibbous. 
1. R. HISPIDA, Linnous. Leaves unequally pinnate. Stem hispid. Racemes axillary.Rose Acacia. Native of the Southern States; flowering throughout the summer.

Few deciduous trees are more ornamental than this when well grown and covered with its racemes of rose-colored flowers. It delights in a moist rich soil, though not by any means wet. If grafted on the next described species it becomes more vigorous. On its own roots it will frequently grow twenty feet high. On a dry soil it never reaches any great height, though it will flower freely. It is readily propagated by cuttings of the roots placed in a slight hotbed early in spring.

2. R. PSEUD-ACACIA, Linnous. Leaves unequally pinnate. Racemes loose, pendulous, pedicels or flowerstalks one-flowered. Stipules spinose.-Yellow locust. Flowering in May.

This varies from one of the handsomest of ornamental trees to one of the ugliest. When young, with its bold round head, its elegant foliage and luxuriant growth, profusely covered with its large clusters of deliciouslyscented flowers, it laughs at its rivals. But 
the case is different as it advances in age; large branches broken off by every stiff breeze, others dying "voluntarily," like suicides through grief for loss of the power to please; then the borer, which attacks them most unrelentingly, and its innumerable suckers, make a bad end to its chapter of history. It thrives best in a cool rich loam, and is very readily propagated from its seeds, sown either when ripe or in the spring.

There are many varieties, differing chiefly in the forms of their leaves.

The R. macrophylla is common now with us, and also the $R$. tortuosa, with its curiously twisted branches.

The R.viscosa, known as the clammy locust, the branches and legumes being very clammy and sticky, is probably a good species.

Salisburia, Smith.-Nat. Ord. Taxaceæ. Monœcia, Polyandria, Linn. Staminate flowers axillary, filiform, pedunculate. Fertile flowers terminal, solitary on simple or branching peduncles. Ovule naked, seated in a cupshaped disk, the disk finally becoming fleshy, 
embracing the base of the nut-like seed (abridged from Flora Cestrica).

1. S. AdIantifolia, Smith. Leaves pectinate or comb-shaped, somewhat wedge-shaped at the base, irregularly cut or scolloped on the margin, and marked with straight divergent veins.-Ginko; maiden hair tree. Native of Japan.

Though classed by Loudon as a monœcious. plant, in a private letter in my possession he speaks of it as a diøecious one. I believe our specimens have not yet flowered. As an ornamental tree it claims much attention. Its stem is very straight, resembling in that respect, as well as in color, that of the tulip tree. The leaves are of a bluish-green tinge, and from their fern-like appearance, attract much attention. The branches come out of very variable vigor, and extend nearly horizontally. It is a very artificial-looking tree, and very appropriate for associating with architectural objects. It thrives best in a deep rich loam on a dry subsoil. The handsomest trees, being the original of Mr. Hamilton's introduction, are at the Woodlands; the 
Bartram specimen is sixty-one feet high and three feet eight inches in circumference.

It is generally propagated by layers, put down as soon as the young wood is ripe, being first notched as for a carnation. The stool of layers should be protected from frost. When rooted, they are easily managed afterwards.*

There are some very fine specimens of this tree in Mr. Pierce's arboretum, little if any inferior to the Bartram specimens.

Salix, Linnoeus.-Nat. Ord. Salicaceæ. Diœcia, Diandria, Linn. Catkins with the scales entire. Calyx wanting. Staminate flowers with 1-6 stamens, filaments sometimes united. Pistillate flowers. Stigma 2lobed, with one or more glands contiguous to the pistil.

The WILLOW TRIBE has not as yet met with thàt distinction as affording ornamental trees which it deserves. I fear that Juliet's

* Since the above was written, I learn that trees have produced fruit in France. So that the easiest manner of increasing our stock of this valuable tree will be by importing seedlings. 
doctrine, that "a rose by any other name will smell as sweet," has been inverted in this case, and that the name "willow" has become so associated with the idea of a swamp, except in the instance of the Babylonian, that all willows seem to "smell swampy" to the ornamental planter. But though many of them thrive in moist places, it is not so in all the kinds. Some of them do well in the driest soils, and are adapted to ornament every situation. They are destined yet to receive considerable attention. So far there are but few in cultivation; the following kinds are for the most part to be found growing only in the collection of my friend Evans.

1. S. Acuminata, Smith. Stamens 2. Leaves lanceolate oblong, pointed, wavy, finely toothed, glaucous and downy beneath. -Large-leaved willow. Native of England.

It grows twenty or thirty feet high, with an erect, coarse, and stiff habit; its chief beauty consisting in its fine foliage. It thrives best in a low wet situation, but will do very well in a dry one.

Like all the willows, this may be readily struck by cuttings or "truncheons" of the 
one or two year old wood, the latter making vigorous trees the soonest. The pieces, being cut into lengths about three inches long, may be stuck their full length in any moist waste piece of ground any time in early spring before the bursting of the bud.

2. S. ALBA, Linnceus. Leaves elliptic-lanceolate, acuminate, toothed, white and silky beneath, the lowest teeth glandular. Flowers appearing with the leaves. Ovaries smooth, sessile.-White willow. Native of Europe. Naturalized in the United States.

A handsome round-headed tree, growing well in any soil or situation, where it will easily attain a height of fifty feet. In wet swampy places I have seen it between seventy and eighty, and with a trunk of large diameter.

3. S. ALBA, var. Vitellina. S. vitellina, Linnceus, now reduced to a variety of alba, has the leaves shorter and broader, and more spreading orange-yellow branches, but is in every other respect similar. Its golden bark contrasts beautifully with its deep-green leaves, and even in winter imparts a cheerfulness to garden scenery. 
4. S. BABYLONICA, Linnoeus. Leaves lanceolate, acuminate, serrate, glabrous, glaucous beneath.-Weeping willow. Native of Asia.

A detailed description of this fine tree is unnecessary, so well is it known. It is peculiarly fitting to accompany architectural objects. Its lightness, and graceful elegance, throw on all around a softness that is peculiarly pleasing. By ponds, lakes, or small streams it is highly appropriate, and in any still, quiet scenery, as a shade to an arbor or place devoted to meditation or study, it adds an interest few trees can create. In very gay, rugged, stiff, or bold scenery it is out of place, except in peculiar instances, where bold contrasts can be introduced with effect. It will thrive in almost any soil, refusing only those actually wet or sodden; but in a dry deep loam, contiguous to moisture, it grows with a surprising rapidity.

$S . B$. annularis has its leaves always curled. As a curiosity it may please; but as an ornamental tree will never be popular. A curled leaf will ever be associated with disease, or insects. 
5. S. CAPREA, Linnoeus. Stamens two. Leaves roundish-ovate, pointed-serrate, waved, veins much netted, pale and downy beneath. -Goat-willow. Native of Britain.

There is a noble specimen of, I believe, this species in the fine arboretum of $\mathrm{Mr}$. Pierce, which is five feet in circumference, and probably forty feet high. Its head is very regular, round, and spreading. $\mathrm{Mr}$. Evans has a variety with variegated leaves. Its foliage is very dense, imparting a grateful shade. It grows well in the driest soils, but does best in those inclining to moisture.

6. S. Croweana, Smith. Leaves elliptical, slightly serrated, glaucous beneath. Ovary silky. Stamens united at the base.-Crowe's willow.

This can scarcely be considered as a tree. In very wet soils, in which it delights, it will grow from ten to fifteen feet.

7. S. DAPHNOIDES, Villars. Leaves broadly lanceolate and pointed, with glandular serratures, smooth and glaucous beneath. Catkins appearing before the leaves.-Daphne willow. Native of Switzerland.

A fine species, growing from thirty to forty 
feet high. Its dark, mealy-looking bark gives it a very unique appearance.

8. S. DEcIPIENs, Smith. Stamens two. Leaves lanceolate, pointed, serrate, very smooth. Branches smooth and highly po. lished. - White Welsh-willow. Native of Britain, but said to be naturalized in America.

A tree of upright growth, and often exceeding forty feet. Its young shoots are stained with red, and those of the preceding season have a yellowish cast. It will thrive well in a dry soil.

9. S. Forbyana, Smith. Stamen one. Leaves lanceolate-oblong, serrated, glabrous, with small downy stipules.-Forby's willow. Native of England.

This is a small tree, not over twelve feet high, with very twiggy, slender, pale-green, and glossy stems. It thrives best in a wet soil.

10. S. Forsteriana, Smith. Leaves ellipticobovate, acute, crenate, slightly downy, glaucous beneath. Catkins long, narrow. Germen awl-shaped, silky. Branches slightly downy.- 
Forster's mountain willow. Native of Scotland.

Growing to about fifteen feet high, or probably higher in a deep rich loam, not liable to become too wet.

11. S. FRAGILIS, Linnoeus. Stamens two. Leaves ovate-lanceolate, pointed, serrate, very glabrous.-Crack willow. Native of Britain.

In moist places this will frequently grow to eighty or ninety feet high. Its chief beauty consists in its silky catkins.

12. S. F. Russelliana, Carey. Leaves lanceolate, acuminate, serrate-dentate with the teeth incurved, subglaucous beneath, and slightly silky while young. Stipules semicordate. Styles conspicuous.-Bedford willow. Native of Britain, and naturalized in the United States.

Very nearly resembling the preceding, and, for ornamental purposes, superior to it. It will thrive well in drier ground.

13. S. HIRTA, Smith. Leaves elliptic heart-shaped, pointed, finely crenate, downy on both sides. Stipules half heart-shaped, nearly glabrous. Branches densely hairy.Hairy willow. Native of Britain. 
Growing twenty or thirty feet high, with a very erect habit of growth. It thrives best in a deep rich loam, inclining to moisture. 14. S. NIGRA, Marshall. Stamens 3-4, or 6. Styles short. Leaves narrow-lanceolate, tapering and acute at each end, smooth and green on both sides, with the petiole and midrib pubescent.-Black willow. Native of the United States.

A small tree from fifteen to twenty feet high, with a dark-colored rough bark, and with the young branches dark purple. It grows naturally in low grounds contiguous to moisture.

15. S. PENTANDRA, Linnoeus. Stamens five. Leaves ovate, pointed, crenate, glandular, broad, shining, having a fragrance when slightly dried.-Shining willow. Native of Europe and the United States.

This grows about twenty feet high, and is the most ornamental of the tribe. It delights in a moist situation. Its flowers appear later in the season than most other species. Our S. lucida, Muhlenberg; and S. Meyeriana, Willdenow, of Germany, are probably included in this. 
16. S. POMERANICA, Willdenow. Leaves lanceolate, tapering to both extremities, about four inches long, smooth and shining above, glaucous beneath. Catkins about one inch long. Branches copiously covered with small yellow dots.-Pomeranian willow.

Somewhat allied to $S$. daphnoides, growing about the same height, and equally as ornamental.

17. S. Rotundata, Forbes. Leaves roundish, bluntly serrate, glabrous and shining above, glaucous, netted, and slightly hairy beneath. Stipules rounded, serrate, and glandular.-Round-leaved willow. Native of Switzerland.

One of the most distinct-looking species known to me, growing about fifteen or twenty feet high.

18. S. RUBrA, Hudson. Stamens two, combined at the base. Leaves linear-lanceolate, acuminate, serrate, glabrous, green on both sides. Capsules sessile, very pubescent.Red willow. Native of Britain.

A small tree of ten or twelve feet high, with long narrow leaves, and twiggy branches. It does best in moist situations. 
19. S. viminalis, Linnceus. Stamens two. Leaves linear, inclining to lanceolate, long, but not more than half an inch wide; mar. gins entire, wavy, snow white and silky beneath.-Twiggy, or osier willow. Native of Britain, but I believe naturalized in the States.

Generally grows about twenty feet high; its long, narrow leaves render it highly ornamental. It will grow very well in the driest soils, but prefers the neighborhood of water.

SopHora, Linnous.-Nat. Ord. Fabaceæ. Decandria, Monogynia, Linn. Calyx 5-toothed. Corolla butterfly-shaped, with the wings of the same length as the upper petal (vexillum). Legume bearded; many-seeded.

1. S. JAPONICA, Linnoeus. Leaves pinnate, leaflets many, ovate, smooth.-Japan sophora. Flowers in August.

A most beautiful tree, somewhat resem. bling the locust in its appearance, whether considered in its outline, flower, or foliage. Its average growth is about forty feet, thriving best in a deep rich loam, moderately dry. It is readily propagated by seeds, when they 
can be obtained, which are best sown as soon as ripe. The most common mode is by layers, which may be put down as soon as the wood is ripe, protecting them from frost in winter; they will be mostly rooted sufficiently to take up in spring. Cuttings, selected with care, will also root pretty well if put in as soon as the wood is ripe, and protected from severe frost, carefully guarding against damp.

S. J. pendula, a fine weeping variety, is also in our collections.

Styrax, Linnceus.-Nat. Ord. Styraceæ. Decandria, Monogynia, Linn. Corolla twisted to the left, funnel-form. Fruit a two-seeded drupe.

1. S. GRANDIFOLIUM, Aiton. Leaves large, obovate, silky beneath. Lower peduncles axillary, solitary, one-flowered.-Large-leaved storax. Native of the Southern States. Flowers in July.

In cultivation this becomes a tree fifteen or twenty feet high, and is one of the most ornamental of its class, whether we consider its large leathery leaves, or numerous snow- 
white flowers. It delights in a light gravelly loam, where the roots are contiguous to moisture, and in a slightly shaded situation. It is best propagated by layers put down just before the bursting of the buds, notched like a carnation; they will root before fall. A specimen at Bartram is about twenty-five feet high and fifteen inches in circumference.

Taxodium, Richard.-Nat. Ord. Pinaceæ. Monœcia, Monadelphia, Linn. Male catkins disposed in a pyramidal round spike. Pollen of each flower borne in five cases, attached to the scale on its inner face. Female catkins two or three together, near the base of the spike of male catkins. Strobile globose. Scales peltate, angled.

T. DIsTichUm, Richard. Branches distichous. Leaves linear.-Deciduous or bald cypress. Native of the Southern States.

This is a noble deciduous tree, sometimes attaining one hundred and fifty feet high with a circumference of thirty. When young it has a very regular pyramidal form, becoming round-headed with age, and ultimately rather flat and spreading. The fine- 
ness of its foliage contrasts strikingly with its strong rugged appearance, and the palegreen hue of its leaves with the cedar-like tint of its branches. When growing luxuriantly, it is lined with deep ribs, as if the one trunk were made up of a number of small ones; add to this the numerous "knees," like large beehives, which it throws up for many feet around, and we have a specimen of arborial picturesque beauty not easily surpassed. The Bartram specimen is one hundred and twenty-five feet high and twenty feet in circumference. It grows best in moist swampy places; or, if in dry soil, near a spring or contiguous to moisture. It is readily propagated from seeds sown early in spring in sandy loam, in a rather moist and shaded situation. The following spring they may be put into nursery rows. They transplant pretty well at all times with care.

T. D. pendulum is a fine variety with drooping leaves. In other respects much the same as the preceding.

Taxus, Linnoeus. - Nat. Ord. Taxaceæ. Diœcia, Monadelphia, Linn. Staminateflowers 
bursting from several opposite, imbricated, adjoining, bud-like scales. Column of stamens surmounted by many peltate 8-cleft anthers. Pistillate flower solitary, with imbricated scales at the base. Fruit a single nut em. bedded in a succulent cup, the calyx.

1. T. BACCATA, Linnoeus. Leaves linear, approximating dark-green.-English yew.

Opinion is divided with regard to the merits of this tree in ornamental gardening. Some deem that its long association with English churchyards and cemeteries, suggests ideas too funereal for the life-enjoying pleasures of a garden. Others look on the well. known degree of abuse it will submit to, as a subject of pleasing reflection, suggestive of the victorious nature of meek, uncomplaining, persevering effort in overcoming all obstacles.

But for the once setting aside both poetry and association, our collections are too scarce of evergreens to allow us to dispense with one, and for my part I admire the yew. There is a very fine specimen planted by Young, before mentioned as "the king's Botanist," in friend Longstreth's garden in Kingsessing, probably thirty feet high, and with 
its branches extending nearly as far horizontally. It loves a deep rich loam, but will un. dergo any soil or treatment. It may be propagated by seeds, layers, or cuttings. The former rarely germinate the first year, and are seldom employed. Cuttings are best of two year old wood, put in sand in July or August, slightly shaded and kept moist, with some protection through winter. There are several fine varieties, the commonest being the Irish yew (T. B. fastigiata, Lindley); the weeping yew (T.B. Dovastoni), with very fine broad foliage and pendulous branches; the silver variegated (T. B. elegantissima); the gold variegated, and the erect branching (T. B. erecta, Loudon).

2. T. CANAdensis, Willdenow. Leaves linear, revolute on the margins. Receptacle of the staminate flower subglobose.

This is a much smaller tree than the preceding, readily distinguished by the paler foliage and reddish wood.

Soil and propagation as No. 1.

3.* T. NUCIFERA, Linnceus. Seeds inclosed

* The kinds with seed inclosed in the disk, are now, I beliere, referred to Torreya of Siebold. 
by the fleshy disk. Leaves linear, distant.Acorn yew. Native of Japan, where it grows about twenty feet high, with a diffuse and irregular habit. It is in the collection of John Evans. It is often propagated by grafting on the English yew.

Thuja, Tournefort.-Nat. Ord. Pinaceæ. Monœcia, Monadelphia, Linn. Male catkin terminal, solitary. Pollen of each flower contained in four cases attached to the inner face of the scale towards the base. Female catkin terminal. Ovary joined with the bractea, thus forming a receptacle. Ovules two to each receptacle.*

1. T. occidentalis, Linnous. Cones obovate, scaly; seeds winged; branches horizontal, recurved.-American arbor vitæ. Native of the Northern States.

* In accordance with my plan I adhere to the nomenclature in common use, though I cannot help observing that the separation of No. 2 and No. 3 from the genus under the name of Brota, Don, is very judicions, as all who are familiar with the dissimilarity of their fruits will admit. The species not having winged seeds are now referred to Biota. 
An evergreen essential in all collections. It is handsomer than the Chinese kind, though not so generally cultivated. When young, it has a rather slender appearance, but, on becoming older, branches out into a head very similar to the red cedar. The finest Bartram specimen is about fifty-two feet high and three feet ten inches in circumference. It is raised from seed sown in the fall or spring in boxes of light, sandy soil, kept cool and moderately moist till they appear. If sown thinly, they are best left two years in the seed bed, and then removed to nursery rows one foot apart. A cool, rather moist soil, on a dry bottom, seems best adapted for it, but it will do well in any soil not too wet or too stiff.

2. T. orientalis, Linnous. Cones elliptic, scales mucronate beneath the fleshy apex. Branches ascending, branchlets mostly vertical.-Chinese arbor vitæ.

When young, this is handsomer than the last, but can bear no comparison with it when it becomes old. The best Bartram specimen is about twenty-five feet high and three feet in circumference. It is propagated as the last, and also by cuttings of the well ripened wood 
put in sandy soil early in the fall, and slightly protected through winter. It is sometimes raised from layers.

3. T. PENDULA, Lambert. Leaves like small scales, opposite, imbricate, ovate-lanceolate, mucronate, decurrent. Cones ovate-oblong, produced in clusters at the ends of the branches. Seeds wingless.-Weeping arbor vitæ. Native of Japan and China.

A very peculiar looking small tree of about fifteen feet high. Its slender, apparently leafless branchlets, hang down very gracefully. It is one of the prettiest evergreens yet introduced for planting by the sides of walks in the pleasure-ground.

4. T. Plicata, Don. Allied to No. 1. The branchlets are compressed and flattened, shining on the upper surface, and the lower of a dull green, dotted with stomata.-Plicate arbor vitæ. Native of the north-west coast.

A considerable improvement on No. 1, growing more compact, and with a fuller habit of growth, though, I believe, never reaching the same height. 
Tilia, Linnous.-Nat. Ord. Tiliaceæ. Po. lyandria, Monogynia, Linn. Calyx 5-parted, deciduous. Corolla 5-petalled. Capsules globose, downy, 5-celled, opening at the base.

1. T. AMERICANA, Linnœus. Leaves deeply cordate, nearly round, abruptly acuminate, sharply serrate, smooth. Petals with a scale on the inside at the base, notched at the apex. Fruit ovate, ribbed.-American linden. Native of Canada and the Northern States. Flowers in July.

In the Middle States, both this and the fol. lowing species have been very popular as a shade tree. Its yellowish fragrant flowers are so grateful to insects, that the tree becomes disagreeable on their account while it is in flower. It is also very liable to the at tacks of a borer. When full grown, it has a rather irregular round head, and to most tastes has a very pleasing effect. It is easily distinguished from the following, when old, by its round head, and when in fruit by its ribbed fruit, and Mr. Emerson remarks, in his excellent "Trees and Shrubs of Massachusetts," by the young shoots being of a dark-brown or blackish color. In the autumn, the leaves 
turn to a pale lemon yellow, and are amongst the earliest to mark the progress of the season.

The best soil for it is a deep cool loam, though it will grow pretty well in any not liable to extremes of wet or dry. It may be propagated by seed sown as soon as ripe, which will mostly appear the following spring. The most usual plan is by layers put down as soon as the wood is ripe, somewhere about the month of June. Sometimes these layers are tongued and pegged down, at other times merely twisted a little near the base of the stool, which is then moulded up with earth to just above the twisted parts.

The best Bartram specimen on dry soil is eighty-two feet high and five feet ten inches in circumference.

2. T. EUROPGA, Linnceus. Leaves twice the length of the footstalks, glabrous beneath. Petals without nectaries. Flowers appearing a month earlier than the last. Fruit nearly or quite globose.-European linden.

This species grows more regular and conical than the last, and when growing by itself, its branches sweep the ground. In such cases it forms one of the most beautiful ob- 
jects a single tree can afford. It is apt to lose its leaves very early, unless growing in a deep rich loam. It may be propagated as the last. There are many varieties* in our nurseries. The rubra with red shoots, aurea with yellow, platyphylla with broad leaves, parvifolia with small leaves, and the pendula with drooping branches.

3. T. Heterophylla, Ventenat. May be but a variety of No. 1, but is considered by many as distinct. It is the T. alba of Michaux. The leaves are ovate, white and downy beneath, sometimes cordate at the base; oftener obliquely cordate and truncate. It does not grow so high as No.1, and will thrive in heavier soils, especially if near a stream or contiguous to moisture. The commonest weeping linden of the nurseries is of this species, and when grafted standard high on some other kind will form a pretty object. It has a striking peculiarity in the change of the color of the leaves in the fall. A portion

* The nomenclature of the genus is confused. It is difficult to pronounce what is a species and what but a variety. 
will be quite green while the rest are of a bright-yellow. The white linden should be in every collection.

Uluus, Linnoeus.-Nat. Ord. Ulmaceæ. Pentandria, Digynia, Linn. Calyx 5-8-cleft, permanent. Corolla none. Stamens equal to the divisions of the calyx. Fruit a onecelled, one-seeded samara.

1. U. AMERICANA, Linnoeus. Leaves smooth above, oblong ovate, unequal at the base, equally and sharply serrate. Flowers pedicellate. Fruit oval, downy at the margin.American elm.

This fine tree is very popular in many of the Northern States, and deservedly so, for few trees can compare with it in the easy gracefulness of its appearance. It likes not to be crowded by other trees, always in that case losing considerable of it beauty. It is essentially a round-headed tree, and, when old, frequently becomes quite pendulous. It is not at home in wet situations, thriving only in light loose loams. In our district it is so very liable to be preyed upon by insects, that it has lost much of its interest. It will some- 
times reach eighty feet high; but its most usual figure is sixty.

The seed ripens in May, and should be sown at once in a bed of light sandy loam, taking care to keep the bed regularly moist and partially shaded through the season. The most usual mode of propagation is by layers. A "stool" being used for that purpose, the shoots are twisted and moulded up as before described, and in that manner they soon form roots.

There is a weeping variety, U. pendula of Pursh, in our collections, as well as one with purple leaves.

2. U. CAMPESTRIS, Linnoeus. Leaves rhomboid ovate, acuminate, wedge-shaped, oblique at the base, scabrous above, doubly and irregularly serrate, downy beneath, serratures incurved. Fruit oblong, deeply cloven, naked.-English elm.

This is a finer tree than the last, growing larger, and having a stiffer head, and general habit of growth. Mr. Emerson notices that the leaves stay green a much longer period in the fall, than in our kind. 
There is a very fine specimen in Mr. Pierce's arboretum, measuring six feet seven inches in circumference, and is probably ninety feet high. The Cornish elm, U. stricta of Lindley, now considered a variety of this, is also in our collections.

3. U. FULVA, Michaux. Leaves scabrous above. Buds clothed with a brown down. Flowers in dense bundles. Fruit nearly round, naked on the margin.-Slippery elm.

A handsome tree, with magnificent foliage, but without the ample proportions which characterize the other species. It seldom exceeds fifty feet high, and has often a pendulous appearance. It has the advantage of thriving in a low wet soil, where the other kinds will not. The bark is frequently corky. The Bartram specimen is fifty feet high and five and a half feet in circumference, but is nearly dead, owing to the bark having been almost entirely stolen off for medicinal purposes.

4. U. GLABRA, Miller. Leaves ovate, lanceolate, acuminate, doubly serrate, obliquely 
wedge-shaped at the base, smooth above, smooth or glandular below. Fruit obovate, naked, deeply cloven.-Smooth-leaved elm. Native of Britain.

In its native country this grows from sixty to eighty feet high, but the specimens I have fallen in with here are all small. It thrives in similar situations to No. 2.

The Huntingdon, $U$. G. vegeta of Loudon, is also in our collections, as well as the variegated leaved.

5. U. montana, Bauhin. Leaves obovate, cuspidate, wedge-shaped at the base, coarsely and doubly serrate, very scabrous above, downy beneath. Fruit rhomboid oblong, naked, scarcely cloven.-Mountain or wych elm. Native of Britain.

This has not been extensively cultivated here, but will probably prove one of the most desirable of trees. Its dark, ample foliage, and vigorous growth, are amongst the traits of character which commend it. It thrives best in a cool, deep, and rich loam, and is propagated like the rest. The Exeter elm, a variety with very upright growing branches 
and compact habit, is also in our collections, and a very desirable kind, on account of the strong contrasts which can be made with the pendulous varieties.

Virgilia, Lamarck.-Nat. Ord. Fabaceæ. Corolla butterfly-shaped. Fruit a flat, many seeded legume.

V. LUTEA, Michaux. Leaves pinnate, leaflets alternate.-Yellow wood. Native of the Western States. Flowers in July.

A middle-sized round-headed tree, which when in flower is particularly ornamental. These are in clusters larger than the locust, though less odoriferous; pendulous, and of a whitish-yellow color. It is late in putting forth in spring, and one of the first to shed its leaves, which turn to a deep orange yellow in the fall.

It thrives best in a rich light loam, in a cool situation, not exposed to the heat and drought of summer.

It is propagated by seeds sown as soon as they are ripe, in boxes protected from mice and severe frosts. They will appear in spring. 
It also succeeds very well if budded on the sophora in July.

The finest Bartram specimen is fifty feet high and four feet in circumference at the base.

Xanthoxylon, Kunth.-Nat. Ord. Xanthoxylaceæ. Diœcia, Tri-pentandria, Linn. Calyx 3-5-parted. Stamens and petals equal to the divisions of the calyx. Carpels 1-5, with an equal number of styles connected at the apex; 2-valved; 1-2-seeded. Fruit mostly berried. Seeds globose, dark, and shining.

X. FraXINEUM, Willdenow. Leaves with four to five pairs of ovate leaflets. Sterns prickly, prickles stipitate. Petioles unarmed. -Toothache tree; prickly ash. Canada to Kentucky.

A small tree of about fifteen feet high, the which whoever plants will wish he had never seen, on account of its rambling, brambly appearance, and determination to throw up suckers in spite of all opposition.

It is a fit companion for the elder bush which John Bartram, in his correspondence, 
says he rooted out of his garden every year for half his life, but which continued to come up notwithstanding. A specimen at Bartram is about fifteen feet high and six inches in circumference. 



\section{N D E X}

OF

ENGLISH OR COMMON NAMES.

Acacia, rose. Robinia hispida. Ailanthus. Ailantus glandulosus. Althea. Hibiscus syriacus. Angelica tree. Aralia spinosa. Apple, cherry. Pyrus baccata. Apple, double-flowered. Pyrus spectabilis. Arbor vitæ, American. Thuja occidentalis. Arbor vitæ, Chinese. Thuja orientalis. Arbor vitæ, weeping. Thuja pendula. Ash, black. Fraxinus sambucifolia. Ash, blue. Fraxinus quadrangulata. Ash, downy. Fraxinus pubescens. Ash, European. Fraxinus excelsior. Ash, mountain. Pyrus aucuparia. Ash, poison. Rhus venenata. Ash, prickly. Xanthoxylon fraxineum. Ash, red. Fraxinus pubescens. 
Ash, various-leaved. Fraxinus excelsior heterophylla.

Ash, walnut. Fraxinus juglandifolia.

Ash, weeping. Fraxinus excelsior pendula.

Ash, white. Fraxinus americana.

Beam, white. Pyrus aria.

Becch, American. Fagus ferruginea.

Beech, bloody. Fagus sylvatica, sanguinea.

Beech, crested. Fagus sylvatica, cristata.

Beech, cut. Fagus sylvatica, laciniata.

Beech, copper. Fagus sylvatica, cuprea.

Beech, European. Fagus sylvatica.

Beech, water. Carpinus americanus.

Birch, American white. Betula populifolia.

Birch, black. Betula nigra.

Birch, poplar-leaved. Betula populifolia.

Birch, red. Betula nigra.

Birch, sweet black. Betula lenta.

Birch, white. Betula alba.

Bitternut. Carya amara.

Box. Buxus.

Box, Minorca. Buxus balearica.

Buckeye, yellow. Pavia flava.

Buckthorn. Rhamnus cathartica.

Buckthorn, alder. Rhamnus frangula.

Buckthorn, Carolina. Rhamnus caroliniensis.

Buckthorn, sea. Hippophæ rhamnoides.

Bumelia. Bumelia lycioides. 
Butternut. Juglans cinerea.

Buttonwood, American. Platanus occidentalis.

Buttonwood, English. Platanus orientalis.

Catalpa. Catalpa bignonoides.

Cedar, African. Cedrus africana.

Cedar, deodar. Cedrus deodara.

Cedar, Japan. Cryptomeria japonica.

Cedar, Lebanon. Cedrus libani.

Cedar, twisted. Cupressus torulosa.

Cedar, white. Cupressus thuyoides.

Cherry, Chickasaw. Cerasus chicasa.

Cherry, cornelian. Cornus mas.

Cherry, double-flowered wood. Cerasus sylvestris

fl. pleno.

Cherry, English bird. Cerasus padus.

Cherry, mahaleb. Cerasus mahaleb.

Cherry, wild. Cerasus serotina.

Chestnut, chinquapin. Castanea pumila.

Chestnut, common. Castanea vesca.

Chestnut, marrone. Castanea vesca.

Christ's thorn. Paliurus aculeatus.

Club of Hercules. Aralia spinosa.

Crab, plum-leaved. Pyrus prunifolia.

Crab, sweet-scented. Pyrus coronaria.

Cucumber tree. Magnolia acuminata.

Cyrilla. Cyrilla racemiflora.

Cypress, bald. Taxodium distichum.

Cypress, deciduous. Taxodium distichum.

$21 *$ 
Cypress, weeping-leaved. Taxodium distichum pendulum.

Dogwood, alternate-leaved. Cornus alternifolia.

Dogwoood, American. Cornus florida.

Dogwood, English red. Cornus sanguinea.

Dogwood, flowery. Cornus florida.

Dogwood, white-berried. Cornus alba.

Elder, box. Negundo aceroides.

Elm, American. Ulmus americana.

Elm, Cornish. Ulmus campestris var.

Elm, English. Ulmus campestris.

Elm, Exeter. Ulmus montana var.

Elm, Huntingdon. Ulmus glabra var.

Elm, slippery. Ulmus fulva.

Elm, smooth. Ulmus glabra.

Elm, wych. Ulmus montana.

Fir, balsam. Picea balsamea.

Fir, Cephalonian silver. Picea cephalonica.

Fir, doulle balsam. Picea Frazeri.

Fir, noble. Picea nobilis.

Fir, silver. Picea pectinata.

Frantilinia. Gordonia pubescens.

Fringe tree. Chionanthus virginica.

Ginloo. Salisburia adiantifolia.

Fiacklerry. Celtis crassifolia.

Halesia, two-winged. Halesia diptera.

Hackmatack. Larix americana.

Hawthorn, cockspur. Cratægus crus-galli. 
Hawthorn, English. Cratægus oxyacantha. Hawthorn, maple-leaved. Cratægus cordata. Hawthorn, pear-fruited. Cratægus flava. Hawthorn, pear-leaved. Cratægus pyrifolia. Hawthorn, scarlet-fruited. Cratægus coccinea. Hawthorn, Washington. Cratægus cordata. Hawthorn, yellow-fruited. Cratægus flava. Hemlock. Abies canadensis. Hickory, common. Carya tomentosa. Hickory, Illinois. Carya olivæformis. Hickory, mockernut. Carya tomentosa. Hickory, peccan-nut. Carya olivæformis. Hickory, pignut. Carya porcina. Hickory, shellbark. Carya alba. Holly, American. Ilex opaca. Holly, emetic. Ilex vomitoria. Holly, English. Ilex aquifolium. Honey locust. Gleditschia triacanthos. Horn beam, American. Carpinus americana. Horn beam, European. Carpinus betulus. Horn beam, hop. Ostrya virginica. Horse-chestnut, American. Assulus ohiense. Horse-chestnut, British. Assculus hippocastanum. Horse-chestnut, red. Asculus rubicunda. Iron wood. Ostrya virginica. Judas, American. Cercis canadensis. Judas, European. Cercis siliquastrum. Julibrissin. Acacia julibrissin. 
June-berry. Amelanchier botryapium. Juniper, common. Juniperus communis. Juniper, Swedish. Juniperus suecica. Juniper, tall. Juniperus excelsa. Kentucky coffee. Gymnocladus canadensis. Kölreuteria. Kölreuteria paniculata. Laburnum. Cytisus laburnum. Lagerstrœmia. Lagerstrœmia reginæ. Larch, American. Larix americana. Larch, European. Larix europoea. Linden, American. Tilia americana. Linden, European. Tilia europøa. Linden, golden. Tilia europoea aurea. Linden, broad-leaved. Tilia europœea platyphylla. Linden, small-leaved. Tilia europoea parvifolia. Linden, Weeping. Tilia europœea pendula. Linden, white. Tilia alba. Loblolly, bay. Gordonia Lasianthus. Locust, honey. Gleditschia triacanthus. Locust, yellow. Robinia pseud-acacia. Locust, clammy. Robinia viscosa. Locust, yellow large-leaved. Robinia macrophylla. Locust, yellow twisted. Robinia tortuosa. Magnolia, blue. Magnolia acuminata. Magnolia, Chinese. Magnolia conspicua. Magnolia, early. Magnolia grandiflora præcox. Magnolia, heart-leaved. Magnolia cordata. Magnolia, large-flowered. Magnolia grandiflora. 
Magnotia, long ear-leaved. Magnolia auriculata. Magnolia, long-leaved swamp. Magnolia glauca longifolia.

Magnolia, large-leaved. Magnolia macrophylla. Magnolia, Soulange's. Magnolia Soulangeana. Magnolia, swamp. Magnolia glauca. Magnolia, Thompson's. Magnolia grandiflora Thompsoniana.

Magnotia, umbrella. Magnolia tripetala. Magnotia, Yulan. Magnolia conspicua. Maiden hair tree. Salisburia adiantifolia. Maple, ash-leaved. Negundo aceroides. Maple, black sugar. Acer nigrum. Maple, English. Acer campestre. Maple, moozewood. Acer striatum. Maple, mountain. Acer montanum. Maple, Norway. Acer platanoides. Maple, red. Acer rubrum. Maple, silver. Acer dasycarpum. Maple, striped bark. Acer striatum. Maple, sugar. Acer saccharinum. Maple, swamp. Acer rubrum. Maple, sycamore. Acer pseudo-platanus. Mist tree. Rhus cotinus. Mulberry, black. Morus nigra. Mulberry, paper. Broussonetia papyrifera. Mulberry, red. Morus rubra. Mulberry, white. Morus alba. 
Nettle tree. Celtis occidentalis.

Nettle tree, thick-leaved. Celtis crassifolia.

Oak, Barbary. Quercus ballota.

Oak, Bartram. Quercus heterophylla.

Oak, black. Quercus tinctoria.

Oak, black jack. Quercus nigra.

Oak, British. Quercus robur.

Oak, burr. Quercus macrocarpa.

Oak, chestnut. Quercus castanea.

Oak, chestnut white. Quereus prinus.

Oak, cork tree. Quercus suber.

Oak, lyrate-leaved. Quercus lyrata.

Oak, olive fruited. Quercus olivæformis.

Oak, overcup white. Quercus macrocarpa.

Oak, pine. Quercus palustris.

Oak, post. Quercus obtusiloba.

Oak, quercitron. Quercus tinctoria.

Oak, red. Quercus rubra.

Oak, scarlet. Quercus coccinea.

Oak, sessile-fruited, British. Quercus sessiliflora.

Oak, Spanish. Quercus falcata.

Oak, swamp white. Quercus bicolor.

Oak, Turkey. Quercus cerris.

Oak, water. Quercus aquatica.

Oak, water white. Quercus lyrata.

Oak, white. Quercus alba.

Oak, willow. Quercus phellos.

Oleaster. Elæagnus hortensis. 
Osage orange. Maclura aurantiaca.

Papaw. Anona triloba.

Paulownia. Paulownia imperialis.

Pavia, dwarf. Pavia macrostachya.

Peach, double-blossom. Amygdalus persica, fl. pl.

Persimmon. Diospyros virginiana.

Pine, Aleppo. Pinus halapensis.

Pine, Chili. Araucaria imbricata.

Pine, dwarf. Pinus pumilio.

Pine, frankincense. Pinus tæda.

Pine, gigantic. Pinus Lambertiana.

Pine, heary-wooded. Pinus ponderosa.

Pine, Italian stone. Pinus pinea.

Pine, Jersey. Pinus inops.

Pine, loblolly. Pinus tæda.

Pine, lofty or Bhotan. Pinus excelsa.

Pine, pinaster. Pinus pinaster.

Pine, pitch. Pinus rigida.

Pine, Scotch. Pinus sylvestris.

Pine, sea. Pinus maritima.

Pine, Southern swamp. Pinus palustris.

Pine, Swiss stone. Pinus cembra.

Pine, white. Pinus strobus.

Pine, yellow. Pinus mitis.

Plum, American red. Prunus americana.

Plum, seaside. Prunus maritima.

Poplar, abele. Populus alba.

Poplar, American aspen. Populus tremuloides. 
Poplar, Athenian. Populus græca. Poplar, Zalsam. Populus balsamifera. Poplar, Canadian. Populus canadensis. Poplar, cottonwood. Populus angulata. Poplar, gray. Populus canescens. Poplar, large American aspen. Populus grandidentata.

Poplar, Lombardy. Populus dilatata. Poplar, Ontario. Populus candicans. Ptelea. Ptelea trifoliata. Pyrus, snow-leaved. Pyrus nivalis. Rowan. Pyrus aucuparia. Sassafras. Laurus sassafras. Service-tree, wild. Pyrus torminalis. Shad flower. Amelanchier botryapium. Snowdrop tree. Halesia tetraptera. Sophora, Japan. Sophora japonica. Sophora, weeping. Sophora japonica pendula. Sorbus or service tree. Pyrus domestica. Sorrel tree. Andromeda arborea. Sour gum. Myssa multiflora. Spindle tree, broad-leaved. Euonymus latifolius. Spindle tree, dark purple. E. atro-purpureus. Spindle tree, European. E. europæus. Spruce, black. Abies nigra. Spruce, Douglass's. Abies Douglassii. Spruce, hemlock. Abies canadensis. Spruce, morinda. Abies Smithiana. 
Spruce, Norway. Abies excelsa.

Spruce, Smith's Himalayan. Abies Smithiana.

Storax, large-leaved. Styrax grandifolium.

Sumach, poison. Rhus venenata.

Sumach, Siag's horn. Rhus typhina.

Sweet gum. Liquidambar styraciflua.

Toothache tree. Xanthoxylon fraxineum.

Tree of Heaven. Ailantus glandulosa.

Tulip tree. Liriodendron tulipifera.

Tupelo. Nyssa multiflora.

Walnut, black. Juglans nigra.

Walnut, English. Juglans regia..

Walnut, white. Juglans cinerea.

Willow, Bedford. Salix Russelliana.

Willow, black. Salix nigra.

Willow, crack. Salix fragilis.

Willow, Crowe's. Salix Croweana.

Willow, curled. Salix babylonica annularis.

Willow, daphne. Salix daphnoides.

Willow, Forby's. Salix Forbyana.

Willow, Forster's. Salix Forsteriana.

Willow, goat. Salix caprea.

Willow, hairy. Salix hirta.

Willow, large-leaved. Salix acuminata.

Willow, osier or twiggy. Salix viminalis.

Willow, Pomeranian. Salix pomeranica.

Willow, red. Salix rubra.

Willow, round-leaved. Salix rotundata. 
254 INDEX OF ENGLISH NAMES.

Willow, shining. Salix pentandra.

Willow, weeping. Salix babylonica.

Willow, white. Salix alba.

Willow, white Welsh. Salix decipiens.

Witch hazel. Hamamelis virginica.

Yellow wood. Virgilia lutea.

Yew, acorn. Taxus nucifera.

Yew, Canadian. Taxus canadensis.

Yew, English. Taxus baccata.

Yew, Irish. Taxus baccata fastigiata.

Yew, silver variegated. Taxus baccata elegantissima.

Yew, weeping. Taxus baccata pendula, or Taxus Dovastoni. 


\section{A P PE N D IX.}

Puants recently introduced into cultivation, or which have not come under the personal observation of the author.

Abies alba.

Abies dumosa.

Abies gigantea.

Abies Menziesii.

Abies obovata.

Acer circinatum.

Acer obtusatum.

Acer opalus.

Esculus hippocastanum, double-flowered.

Esculus laciniatum.

Alnus glutinosa.

Alnus laciniata.

Alnus serrulata.

Anelanchier florida.

Betula excelsa.

Betula papyracea.

Castanea vesca asplenifolia.

Castanea vesca laciniata.

Chionanthus maritima.

Cornus paniculata.

Cratægus Layi. 
Cratægus orientalis.

Cryptomeria Lobbiana.

Elæagnus flava.

Elæagnus parviflora.

Fagus sylvatica macrophylla.

Fraxinus excelsior argentea.

Juglans regia laciniata.

Juniperus phœnicia.

Larix Griffithii.

Larix Tyrolosa.

Ornus Europæus.

Ornus latifolius.

Picea Pindrow.

Picea pinsapo.

Picea Webbiana.

Pinus Austriaca.

Pinus Coulterii.

Pinus Gerardiana.

Pinus Hartwegii.

Pinus insignis.

Pinus Laricio.

Pinus Massoni.

Pinus monticola.

Planera Richardii.

Platanus acerifolia.

Platanus palmata.

Platanus pyramidalis.

Populus acerifolia.

Populus cordifolia.

Populus heterophylla.

Populus heterophylla pendula.

Pterocarya caucasica. 
Pyrus lanuginosa.

Pyrus orientalis.

Pyrus rivularis.

Pyrus salicifolia.

Pyrus variolosa.

Pyrus vestita.

Salix candida.

Salix fusca (grafted).

Torreya taxifolia. 
